UNIVERSIDADE DE SÃO PAULO

ESCOLA DE ENGENHARIA DE SÃO CARLOS

DEPARTAMENTO DE ESTRUTURAS

CYNTHIA MEILLI SILVA ARAUJO

\title{
ESTUDO DA TRANSFERÊNCIA DE FORÇAS DE CISALHAMENTO NA LIGAÇÃO ENTRE PILARES MISTOS PREENCHIDOS E VIGAS
}





\title{
ESTUDO DA TRANSFERÊNCIA DE FORÇAS DE CISALHAMENTO NA LIGAÇÃO ENTRE PILARES MISTOS PREENCHIDOS E VIGAS
}

\begin{abstract}
Dissertação apresentada à Escola de Engenharia de São Carlos, da Universidade de São Paulo, como parte dos requisitos necessários para a obtenção do Título de Mestre em Engenharia de Estruturas.
\end{abstract}

Área de Concentração: Estruturas

Orientadora: Prof ${ }^{a}$. Dr ${ }^{a}$. Ana Lucia H. de Cresce El Debs

São Carlos

2009 
AUTORIZO A REPRODUÇÃO E DIVULGAÇĀO TOTAL OU PARCIAL DESTE TRABALHO, POR QUALQUER MEIO CONVENCIONAL OU ELETRÔNICO, PARA FINS DE ESTUDO E PESQUISA, DESDE QUE CITADA A FONTE.

Estudo da transferência de forças de cisalhamento na ligação entre pilares mistos preenchidos e vigas / Cynthia Meilli Silva Araujo; orientadora Ana Lucia H. de Cresce El Debs. -- São Carlos, 2009.

Dissertação (Mestrado-Programa de Pós-Graduação e Área de Concentração em Engenharia de Estruturas) -- Escola de Engenharia de São Carlos da Universidade de São Paulo, 2009 .

1. Estrutura mista. 2. Pilar misto preenchido. 3. Ligação viga-pilar. 4. Cisalhamento. 5. Análise experimental. 6. Análise numérica. I. Título. 




\section{FOLHA DE JULGAMENTO}

Candidata: Engenheira CYNTHIA MEILLI SILVA ARAUJO.

Dissertação defendida e julgada em 08/09/2009 perante a Comissão Julgadora:

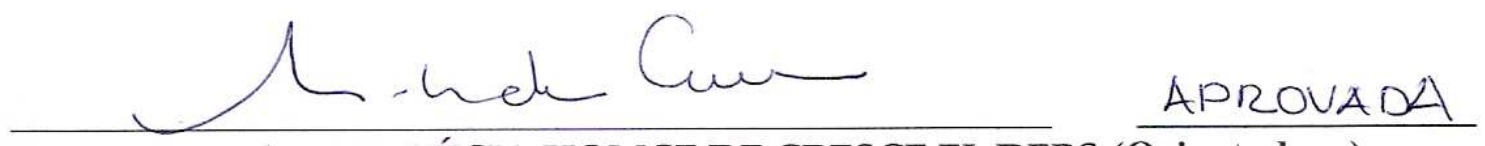

Prof ${ }^{a}$. Associada ANA LÚCIA HOMCE DE CRESCE EL DEBS (Orientadora)

(Escola de Engenharia de São Carlos/USP)

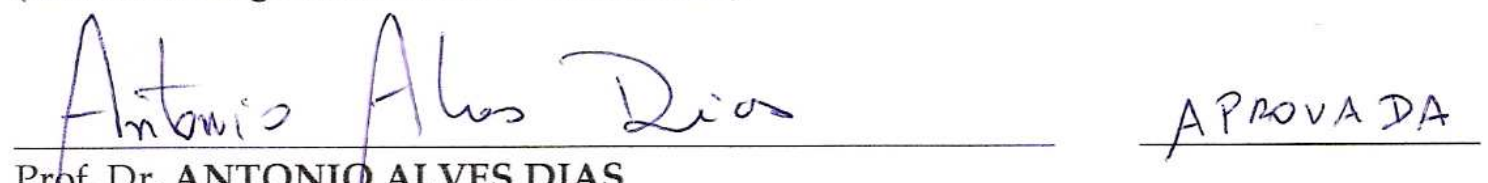

Prof. Dr. ANTONIQ ALVES DIAS

(Escola de Engenharia de São Carlos/USP)

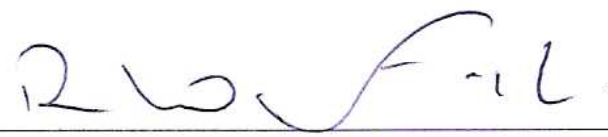

Prof. Associado RICARDO HALLAL FAKURY

(Universidade Federal de Minas Gerais/UFMG)
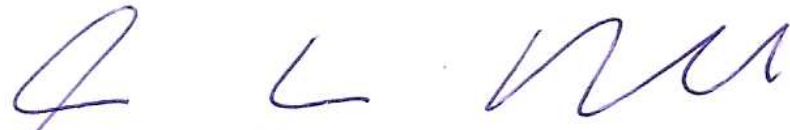

Prof/Associado MARCIO ANTONIO RAMALHO

Coordenador do Programa de Pós-Graduação em

Engenharia Civil (Engenharia de Estruturas)

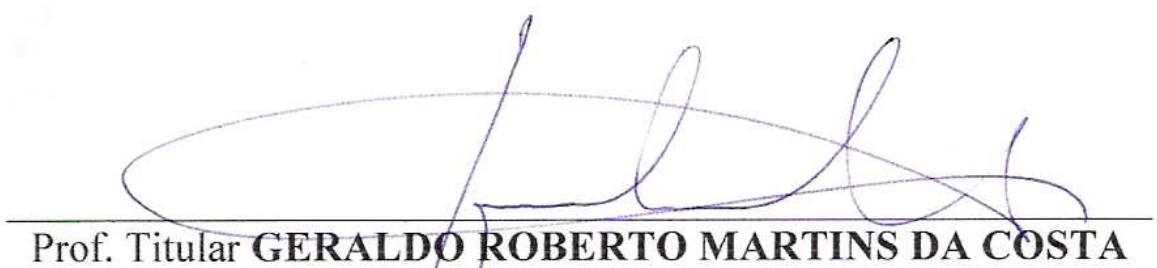

Presidente da Comissão de Pós-Graduação 

Aos meus pais, Salvio e Terezinha, com carinho e como reconhecimento de todo o apoio e amor e dedicação. 



\section{AGRADECIMENTOS}

À minha orientadora Professora Ana Lúcia, por todo o seu apoio, atenção, compreensão. Professora, obrigada pela oportunidade de realizar esse trabalho sob sua orientação.

À Silvana e Alex, agradeço ao incentivo para o mestrado, a amizade, o carinho, a ajuda, as palavras amigas e de conforto. Obrigada por terem acreditado em mim. Vocês foram os primeiros responsáveis por esse grande crescimento na minha vida.

Aos meus pais, Salvio e Terezinha, que me apoiaram na decisão de prosseguir os estudos, mesmo sendo essa decisão no início tão difícil para nós três, saudade e muita saudade. Obrigada por me amarem tanto e estarem sempre presentes mesmo que pelo telefone me transmitindo toda a segurança e carinho que só encontro em vocês. Essa conquista do mestrado é nossa.

Aos meus tios, primos e avós por todo o carinho, apoio, preocupação, atenção e por torcerem pelo meu sucesso.

Ao meu querido avô, Henrique, exemplo de luta, trabalho, integridade, esforço e inteligência, que sempre se orgulhou de mim e me incentivou nas diversas etapas da minha vida. Saudades enorme!

À Sabrina, Miguel, Yago e Mariana, pelos momentos de alegria e pelo aconchego de família.

Aos meus queridos e amados amigos, que tenho certeza que foram amizades conquistadas em uma etapa de vida maravilhosa que vivi em São Carlos, obrigada por estarem sempre por perto, por dividirem as alegrias, os momentos de saudade, as risadas, os 
estudos, os segredos, por alimentarem meus sonhos, Ana e Rodrigo, vocês fazem muita falta. Tenho certeza que ainda realizaremos muitas metas juntos! Rodrigo sua ajuda no DIANA foi fundamental para que eu conseguisse desenvolver minha análise numérica, obrigada pela sua disponibilidade, generosidade e atenção.

Agradeço ao casal mais divertido que já conheci, Dani e Leo, vocês não existem! À Renata pelos conselhos. Ao Mineiro, obrigada por me apresentar o mundo sertanejo.

A todos os colegas do departamento, especialmente ao Leandro, Giovani, Erika, Aref, Jonatas, Rômulo e Paccola.

Agradeço também àqueles que me acolheram com tanto carinho em São Carlos: Suzana, Walter, Fernanda, Eduardo, Malu, Negô, Tamyres, Carol...

À Dani Cenci, Rafa, Jú, Wanessa, Aline e Carla lembrarei sempre de todos os nossos momentos de muita alegria e diversão que vivemos juntas.

Aos professores da UFES, Luis Herkenhoff Coelho, Newton Fernando Araújo Brant, Gláucia Penha, Fernando Avancini Tristão e Walnório Ferreira pelo incentivo em ingressar na Pós-Graduação

Aos funcionários da Oficina Mecânica Penazzi e Lombardi.

Aos funcionários do laboratório do Departamento de Engenharia de Estruturas desta Escola: Luiz Vareda, Fabiano, Romeu, Mário, Amauri, Mauri, sem os quais o programa experimental presente neste trabalho não teria sido realizado.

Aos professores e funcionários do Departamento de Engenharia de Estruturas, pela atenção nos momentos em que precisei, sobretudo à Rosi, Nadir, Raquel, Sylvia, Toninho, Eli, Masaki e Melina.

Agradeço ao colega de trabalho Cláudio Zanetti pela ajuda na criação de algoritmos em Word e Excel para agilizar a análise dos meus resultados. 
Aos amigos de Vitória que compreenderam quando não podia estar presentes em muitas confraternizações e encontros, pois tinha necessidade de escrever a dissertação. Ao Carlos pelas incansáveis ajudas quando tinha problemas com o computador, pelo carinho, apoio, companhia, por compartilhar comigo as dificuldades durante o desenvolvimento da dissertação e pela compreensão.

À FAPESP - Fundação de Amparo à Pesquisa do Estado de São Paulo, pela bolsa de estudos e reserva técnica que permitiram o desenvolvimento deste trabaho.

E a Deus por ter me dado a oportunidade de crescer, amadurecer e viver essa experiência incrível que foi fazer mestrado em São Carlos. Obrigada, Senhor, por tudo. 

"Não existe um mapa para a felicidade porque a felicidade consiste exatamente em explorar a vida com paixão e intensidade." Só vivendo intensamente é que conseguimos viver aquilo que queremos viver. A nossa maior loucura é o medo de não tentar." 



\section{RESUMO}

ARAUJO, C. M. S. (2009). Estudo da transferência de forças de cisalhamento na ligação entre pilares mistos preenchidos e vigas. Dissertação. Escola de Engenharia de São Carlos, Universidade de São Paulo.

Este trabalho tem por objetivo investigar as ligações viga - pilar misto preenchido, no tocante à transferência de forças de cisalhamento na região de ligação. O estudo engloba uma investigação experimental com ensaios do tipo push-out com carregamento centrado no núcleo de concreto e uma simulação numérica no pacote computacional DIANA ${ }^{\circledR}$ visando obter dados de comportamento do mecanismo de transferência de forças de cisalhamento, aplicado à região de ligação viga-pilar. Foram utilizados modelos com 800 $\mathrm{mm}$ de altura e seção quadrada de dimensão $(200 \times 200 \times 6,3) \mathrm{mm}$ obtida a partir da composição de dois perfis U $(200 \times 100 \times 6,3) \mathrm{mm}$. A resistência à compressão média do concreto de preenchimento foi de 50MPa. Ao todo, foram ensaiados 3 modelos de ligação, utilizando chapas de extremidade e barras rosqueadas como mecanismo de ligação vigapilar. Como elementos para transferência de forças entre o tubo de aço e o núcleo de concreto foram usados conectores tipo pino com cabeça ou cantoneiras. Os resultados experimentais mostraram a eficiência das barras rosqueadas e dos conectores de cisalhamento na transferência dos esforços de cisalhamento na ligação viga-pilar e na interface perfil de aço e concreto. A simulação numérica teve concordância satisfatória com os resultados experimentais obtidos.

Palavras-chave: estrutura mista, pilar misto preenchido, ligação viga-pilar, cisalhamento, análise experimental, análise numérica. 



\section{ABSTRACT}

ARAUJO, C. M. S. (2009). A study on shear forces transfer of connections involving steel beams and concrete-filled steel tubular columns. São Carlos, Dissertation (Master). School of Engineering of São Carlos, University of São Paulo.

In the design of concrete-filled steel tubular columns, the concrete and the steel tube must work together in order to achieve the overall resistance, stiffness and stability requirements. It is important that exists an adequate mechanism to transfer the forces from the steel beam to the steel tube, and then to the concrete core. This work presents a study on shear transfer in connections involving concrete-filled steel tubular columns and steel beams. The work was divided in two parts, being the first an experimental analysis with push-out tests, and the second one a numerical simulation of the tests, using the software DIANA ${ }^{\circledR}$. The tested specimens were $800 \mathrm{~mm}$ height, with square section $(200 \times 200 \times 6,3 \mathrm{~mm})$ obtained from two welded U-shape profiles. A concrete with compressive strength of 50 MPa was used as a filling for the columns. Altogether, three connections with steel end plates and passing bars were tested. Two types of shear connectors between steel column and concrete core were used: stud-bolts and angles, and a reference specimen without connectors was also tested. The results showed the efficiency of the shear connectors in the tranference of forces.

Keywords: Composite element, concrete-filled steel tube column, beam-column, shear, experimental analysis, numerical analysis. 



\section{LISTA DE FIGURAS}

Figura 2.1. Pilar misto revestido (Oliveira, 2008).

Figura 2.2. Pilar misto parcialmente revestido (Oliveira, 2008). 38

Figura 2.3. Pilar misto tipo battened (Oliveira, 2008) 38

Figura 2.4. Tipo de seções transversais pilares mistos preenchidos. (a) Pilar misto de seção quadrada, soldagem de 2 perfis "U". (b) Pilar misto seção quadrada, soldagem de 4 cantoneiras. (c) Pilar misto de seção circular, processo de extrusão. (d) Pilar misto seção circular, chapa com costura (soldagem longitudinal). 38

Figura 2.5. Curva tensão de cisalhamento vs escorregamento. 41

Figura 2.6. Mecanismo de transferência da aderência por adesão. (Johansson, 2002). 42

Figura 2.7. Mecanismo de transferência aderência mecânica. (Johansson, 2002). .43

Figura 2.8. Mecanismo de transferência aderência por atrito. (Johansson, 2002). 44

Figura 2.9. Diagrama força $x$ deslocamento relativo do concreto. (Bianchi, 2002)....... 45

Figura 2.10. Componentes das ações de cálculo e propriedades geométricas para o cálculo da tensão de cisalhamento na interface. Fonte: Johansson (2003) apud Oliveira (2008)....... 46

Figura 2.11. Vista interna dos modelos físicos estudados por Silva (2006). 47

Figura 2.12. Curva força aplicada vs. escorregamento do concreto. Silva (2006). 48

Figura 2.13. Modos de ruptura nos pilares mistos preenchidos estudados por Oliveira (2008). Fonte: Oliveira (2008).

Figura 2.14. Exemplo de ligação entre viga de aço e pilar misto preenchido via chapa passante. De Nardin, 2007.

Figura 2.15. Ligação externa não enrijecida. De Nardin et a.l, 2007. 62

Figura 2.16. Ligação externa enrijecida. Fonte: De Nardin et al., 2007. 62

Figura 2.17. Ligação interna - conectores de cisalhamento e parafusos passantes. Fonte: Ricles et al., 2004 apud De Nardin et al., 2007. 63

Figura 2.18. Ligação mista e pilares preenchidos circulares 63 
Figura 2.19. Esquema dos modelos estudado por Prion (1994) apud De Nardin (2003).....

Figura 2.20. Modos de ruptura para ligações com parafusos passantes

Figura 3.1. Geometria dos modelos de ligação ensaiados. (Medidas em mm). 71

Figura 3.2. Modelo SBC_W: sem conector de cisalhamento. 72

Figura 3.3. Modelo SBC_SB: conector de cisalhamento tipo pino com cabeça. .72

Figura 3.4. Modelo SBC_A: conector de cisalhamento tipo cantoneira. 72

Figura 3.5. Instrumentação dos modelos. 73

Figura 3.6. Distribuição da instrumentação e numeração dos pontos. (Medidas mm). 75

Figura 3.7. Instrumentação do perfil de aço. 76

Figura 3.8. Instrumentação do núcleo de concreto. 76

Figura 3.9. Transdutores de deslocamento nas regiões superior e inferior dos modelos. 76

Figura 3.10. Instrumentação das barras rosqueadas. .77

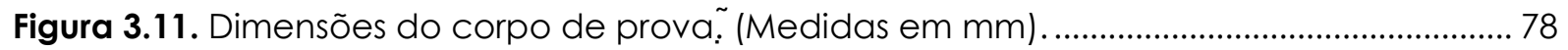

Figura 3.12. Amostras para caracterização do aço do perfil............................................................ 78

Figura 3.13. Ensaio de caracterização do perfil de aço. ..................................................................... 79

Figura 3.14. Curvas do ensaio de caracterização do aço do perfĩ̄............................................... 80

Figura 3.15. Moldagem dos corpos de prova cilíndricos e retangulares..................................... 82

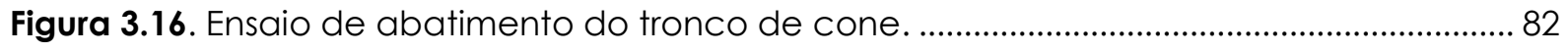

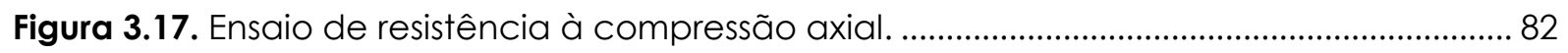

Figura 3.18. Ensaio de resistência à tração por compressão diametral. ......................................... 82

Figura 3.19. Ensaio de compressão para determinação do módulo de elasticidade............... 83

Figura 3.20. Ensaio de energia de fraturamento ............................................................................ 83

Figura 3.21. Conector de cisalhamento tipo pino com cabeça. (Medidas em $\mathrm{mm}$ ) ................ 84

Figura 3.22. Conector de cisalhamento tipo cantoneira. (Medidas em $\mathrm{mm}$ )............................ 85

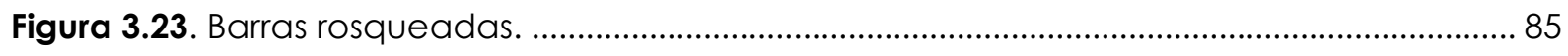

Figura 3.24. Ensaio de caracterização das barras rosqueadas..................................................... 85

Figura 3.25. Tensão X Deformação axial - Ensaio de caracterização das barras rosqueadas. 
Figura 3.26. Porcas sextavadas

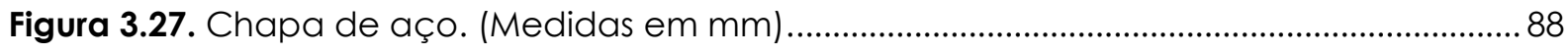

Figura 3.28. Perfis de aço "U" antes e depois da confecção dos furos........................................ 89

Figura 3.29. Confecção dos perfis com conector de cisalhamento tipo cantoneira............... 90

Figura 3.30. Confecção dos perfis com conector de cisalhamento tipo pino com cabeça.. 90

Figura 3.31. Instrumentação das barras rosqueadas. .90

Figura 3.32. Confecção dos pilares metálicos. (a) Calibração da máquina de solda. (b) Soldagem dos perfis "U". (c) Perfis de aço soldados. .91

Figura 3.33. Confecção da instrumentação do perfil de aço........................................................92

Figura 3.34. Instrumentação do núcleo de concreto. .....................................................................93

Figura 3.35. Materiais empregados na confecção do concreto. ................................................94

Figura 3.36. Colocação dos materiais na betoneira para a produção do concreto. ...............94

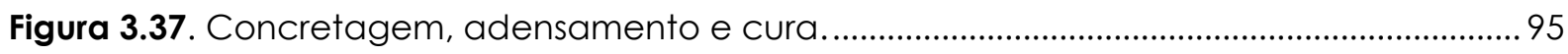

Figura 3.38. Folga nas extremidades do pilar preenchido............................................................. 95

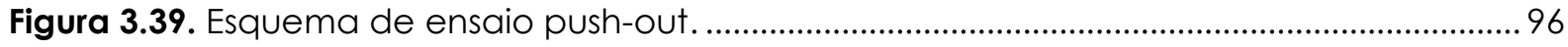

Figura 3.40. Regularização e nivelamento das superfícies. ..............................................................97

Figura 3.41. Verificação do nivelamento das superfícies.............................................................97

Figura 3.42. Aplicação do carregamento no núcleo de concreto.............................................97

Figura 3.43. Configuração do modelo após a ruptura das barras rosqueadas por cisalhamento. (a) Modelo SBC_W. (b) e (c) Modelo SBC_A. .......................................................99

Figura 3.44. (a) Comportamento Força Aplicada versus Deslocamento do Pistão da máquina de ensaios. (b) Zoom da região circular de (a) 100

Figura 3.45. Força aplicada versus Deslocamento no núcleo de concreto modelo SBC_W. 101 Figura 3.46. Força aplicada versus Deslocamento no núcleo de concreto modelo SBC_SB. 101 Figura 3.47. Força aplicada versus Deslocamento no núcleo de concreto modelo SBC_A.. 101 Figura 3.48. Comportamento Força versus deslocamento no núcleo de concreto registrado pelos transdutores de deslocamento. 102 
Figura 3.49. Comparação entre os deslocamentos relativos nos modelos SBC_W e SBC_SB registrados pelo transdutor inferior. 103

Figura 3.50. Posição dos extensômetros no núcleo de concreto. 104

Figura 3.51. SBC_W: Comportamento Força aplicada versus Deformação do Núcleo de Concreto. 104

Figura 3.52 . SBC_SB: Comportamento Força aplicada vs. Deformação do Núcleo de Concreto. 105

Figura 3.53. SBC_A: Comportamento Força aplicada vs. Deformação do Núcleo de Concreto. . 105

Figura 3.54. Deformações no extensômetro C6 posicionado no núcleo de concreto. 106

Figura 3.55. Arranjo dos extensômetros nos modelos ensaiados. 107

Figura 3.56. SBC_W: Comportamento Força Aplicada versus Deformação no perfil de aço. 108

Figura 3.57. SBC_SB: Comportamento Força aplicada versus Deformação no perfil. 108

Figura 3.58. SBC_A: Comportamento Força aplicada versus Deformação no perfil. 108

Figura 3.59. Análise da inclinação das retas referentes às leituras do extensômetro S3R...... 109

Figura 3.60. SBC_W: Comportamento Força aplicada versus Deformação axial nas barras rosqueadas.

Figura 3.61. SBC_SB: Comportamento Força aplicada versus Deformação axial nas barras rosqueadas.

Figura 3.62. SBC_A: Comportamento Força aplicada vs. Deformação axial nas barras rosqueadas.

Figura 4.1. Interface gráfica do iDIANA.

Figura 4.2. Interface gráfico do DIANA . 118

Figura 4.3. Modelos numéricos.

Figura 4.4. Elemento sólido. (DIANA 9.1) 120

Figura 4.5. Elemento de casca - Flat Shell. (DIANA 9.1) 120

Figura 4.6. Elemento $\mathrm{CHX60.}$ 
Figura 4.8. Energia de fraturamento na tração, Farias (2008)

Figura 4.9. Modelos Constitutivos à tração pré-definidos, disponíveis em DIANA $9.1{ }^{\circledR}(2005 b)$

Figura 4.10. Modelos Constitutivos à compressão pré-definidos, disponíveis em DIANA 9.1® (2005b).

Figura 4.11. Fator de redução devido a fissuração lateral (Vecchio \& Collins, 1993)..... 128

Figura 4.12. Propriedades não-lineares do concreto. 129

Figura 4.13. Interface iDiana, propriedades geométricas lineares 130

Figura 4.14. Interface iDiana, propriedades geométricas não - lineares. 130

Figura 4.15. Interface iDiana, propriedade física. 130

Figura 4.16. Interface gráfica - escolha método convergência, passos e iterações. 135

Figura 4.17. Fluxograma de testes realizados. 136

Figura 4.18. Fluxograma representativo da comparação 01. 138

Figura 4.19. Fluxograma representativo da comparação 02. 138

Figura 4.20. Fluxograma representativo da comparação 03. 138

Figura 4.21. Comportamento Força aplicada versus Deformação no núcleo de concreto, com e sem consideração do efeito de confinamento. 139

Figura 4.22 . Comportamento Força aplicada versus Deslocamento do núcleo de concreto, com e sem consideração do efeito de confinamento. 139

Figura 4.23. Comportamento Força aplicada versus Deformação no núcleo de concreto, de acordo com a forma de aplicação da reação de apoio.

Figura 4.24. Comportamento Força aplicada versus Deslocamento do núcleo de concreto, de acordo com a forma de aplicação da reação de apoio. 140

Figura 4.25. Comportamento Força aplicada versus Deformação no núcleo de concreto, de acordo com a forma de aplicação do carregamento.

Figura 4.26. Comportamento Força aplicada versus Deslocamento do núcleo de concreto, de acordo com a forma de aplicação do carregamento. 
Figura 4.27. Deformada em $z$, do modelo para o carregamento apenas no núcleo de concreto.

Figura 4.28. Deformada em z do modelo para carregamento na seção mista. 143

Figura 4.29. Deformada em z, da barra rosqueada para o carregamento apenas no núcleo de concreto. 144

Figura 4.30. Deformada em z da barra rosqueada para carregamento na seção mista. ... 144

Figura 5.1. Comportamento Força aplicada versus Deformação no núcleo de concreto... 150

Figura 5.2. Comportamento Força aplicada versus Deslocamento do núcleo de concreto. 150

Figura 5.3. Comparação do deslizamento relativo aço-concreto 151 


\section{LISTA DE TABELAS}

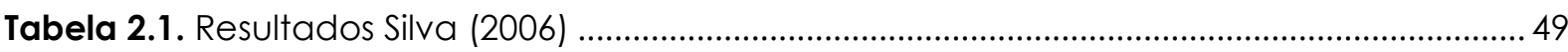

Tabela 2.3 . Tensão de cisalhamento resistente de cálculo ...........................................................55

Tabela 2.3. Força de protensão mínima em parafusos ASTM. Fonte: ABNT NBR 8800:2008 .......67

Tabela 3.1. Nomenclatura e variável estudada experimentalmente .......................................... 70

Tabela 3.2. Especificação dos extensômetros elétricos empregados............................................. 74

Tabela 3.3. Especificação dos transdutores de deslocamentos .................................................... 74

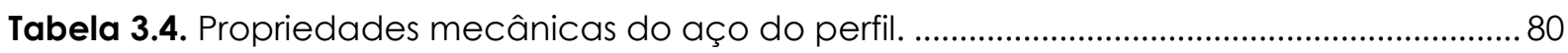

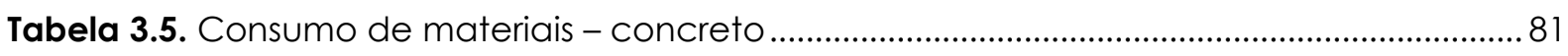

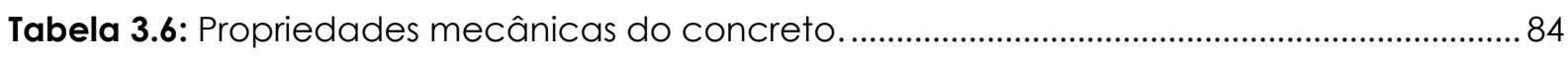

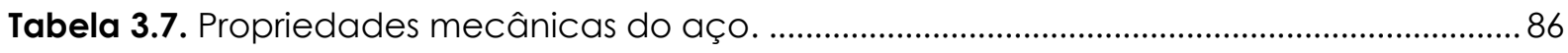

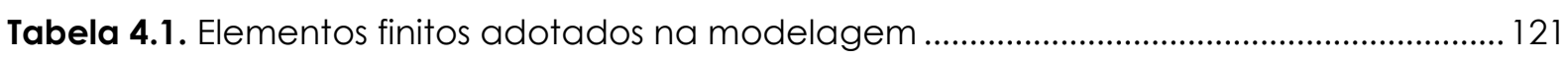

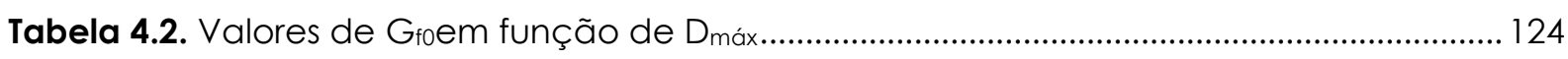

Tabela 5.1. Resultados de Força de Ruptura por Cisalhamento da Ligação ............................. 149 



\section{SUMÁRIO}

1 INTRODUÇÃO

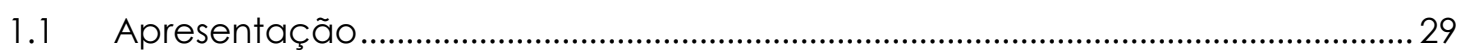

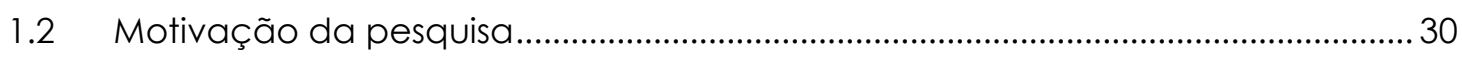

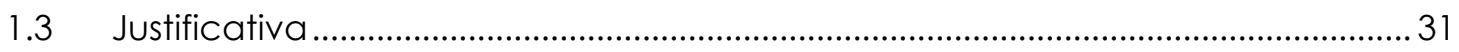

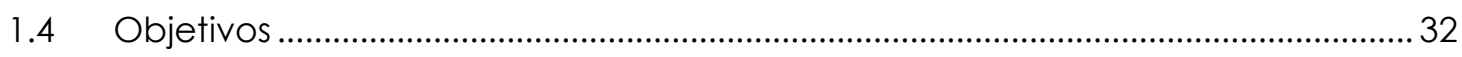

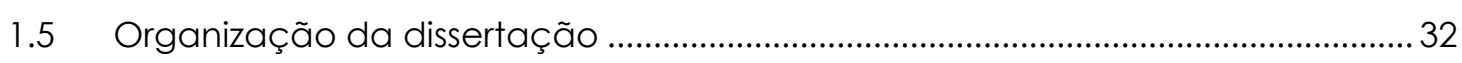

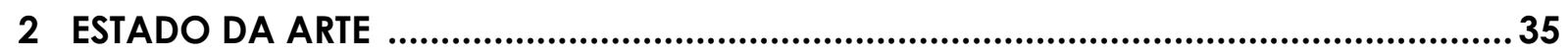

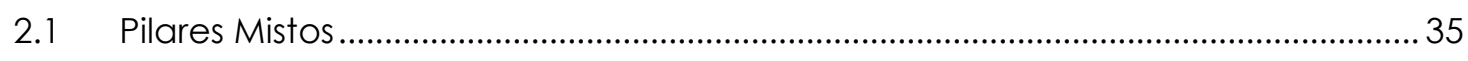

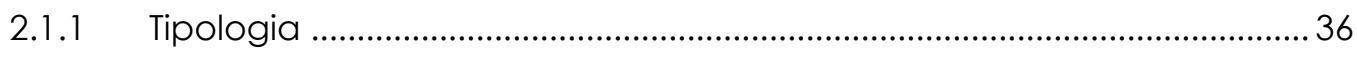

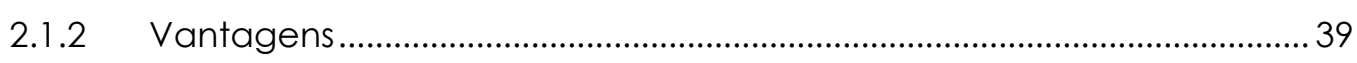

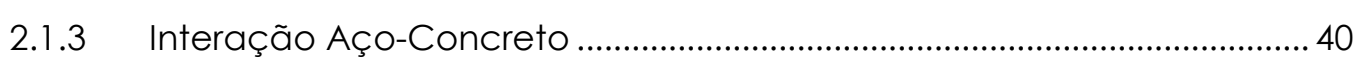

A. Aderência por adesão .................................................................................... 41

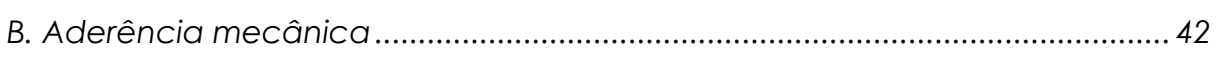

C. Aderência por atrito ........................................................................................ 43

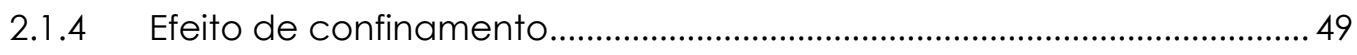

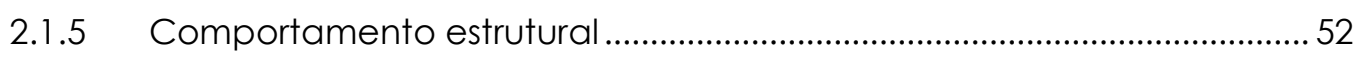

2.1.6 Dimensionamento dos Pilares Mistos Preenchidos de acordo com a

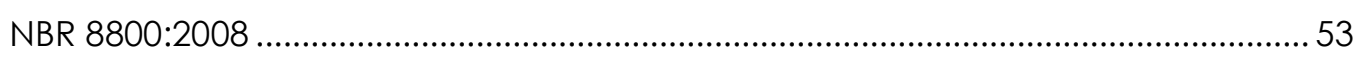

A. Flambagem local dos elementos de aço ........................................................54

B. Cisalhamento nas superfícies de contato entre o perfil de aço e o concreto

C. Força de compressão axial............................................................................ 57

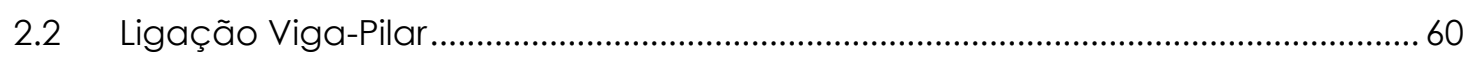

2.2.1 Geometria da ligação viga-pilar ................................................................. 62

2.2.2 Estudo na área de ligação viga-pilar...........................................................63

2.2.3 Dimensionamento de Ligação com Barras Redondas Rosqueadas Segundo a ABNT NBR 8800:2008 …………………...................................................... 66

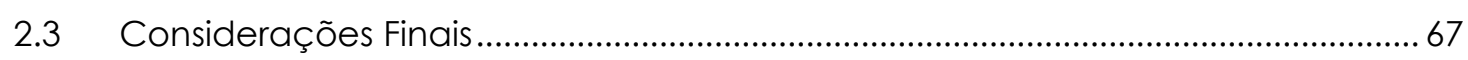

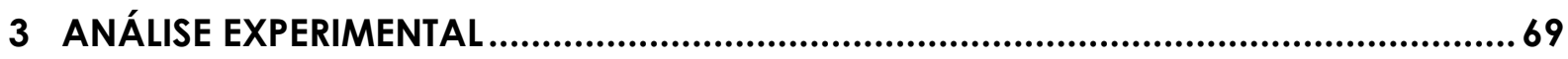

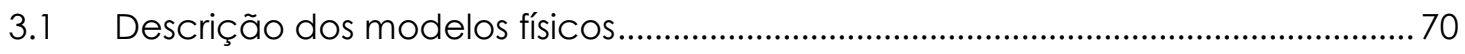




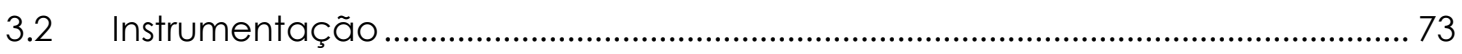

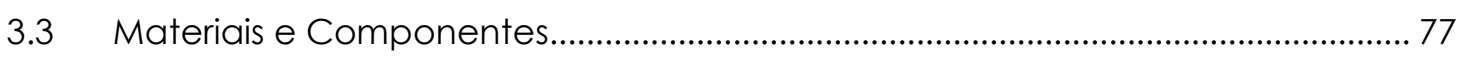

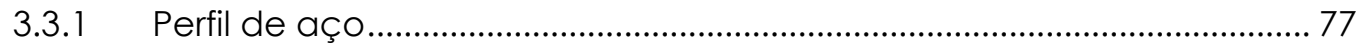

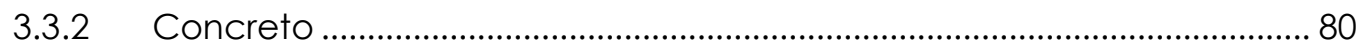

3.3.3 Conector de cisalhamento tipo pino com cabeça .................................. 84

3.3.4 Conector de cisalhamento tipo cantoneira .............................................. 84

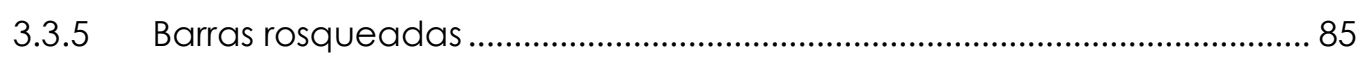

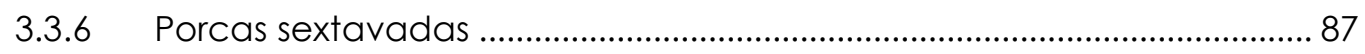

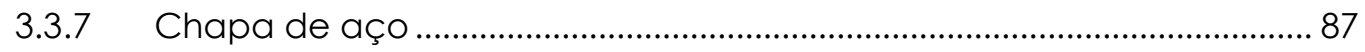

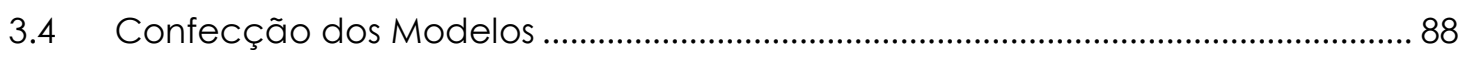

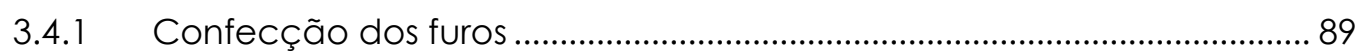

3.4.2 Soldagem dos conectores de cisalhamento .............................................. 89

3.4.3 Instrumentação das barras rosqueadas ........................................................ 90

3.4.4 Colocação das barras rosqueadas no pilar de aço ................................. 91

3.4.5 Confecção dos pilares metálicos .................................................................. 91

3.4.6 Colocação das barras rosqueadas e chapas de aço .............................. 91

3.4.7 Instrumentação dos perfis de aço .................................................................. 91

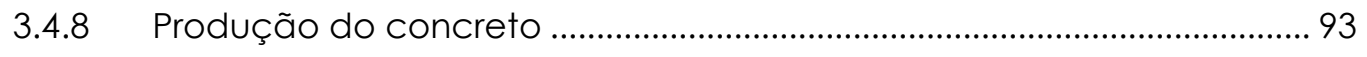

3.4.9 Concretagem, adensamento e cura ……………………….................. 94

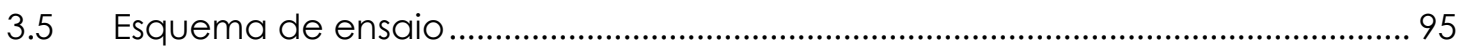

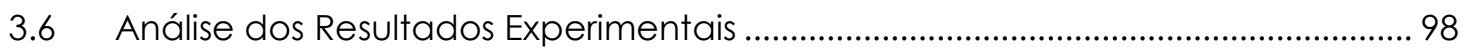

3.6.1 Modo de Falha e Valores Máximos ............................................................. 99

3.6.2 Comportamento Força Aplicada versus Deslocamento do Núcleo de Concreto - deslizamento relativo aço-concreto..................................................... 100

3.6.3 Comportamento Força versus Deformação do Núcleo de Concreto 104

3.6.4 Comportamento Força Aplicada versus Deformação do Perfil de Aço 107

3.6.5 Comportamento Força versus Deformação nas barras rosqueadas.. 110 3.7 Comentários Finais.

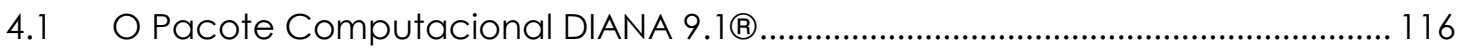

4.2 Critérios Gerais Adotados no Modelo Numérico Estudado .................................. 118 
4.2.1 Definição da geometria

4.2.2 Definição dos elementos finitos ................................................................. 120

4.2.3 Definição das propriedades dos materiais ................................................ 122
A. Concreto .
B. Perfil de aço.
C. Barras Rosqueadas

4.2.4 Definição das condições de contorno e de carregamento ................. 131

4.2.5 Escolha dos parâmetros para efetuar o processamento ........................ 132

4.2.6 Saída de resultados ........................................................................................... 135

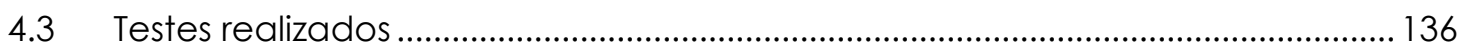

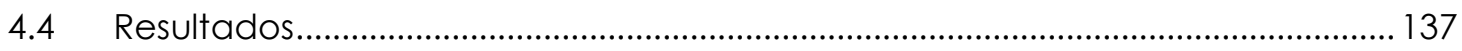

4.4.1 Análise dos resultados da comparação 01: Teste a X Teste b ............... 139

4.4.2 Análise dos resultados da comparação 01: Teste b X Teste d............... 140

4.4.3 Análise dos resultados da comparação 01: Teste a X Teste e ............... 141

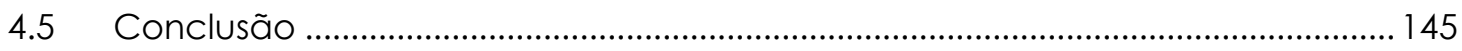

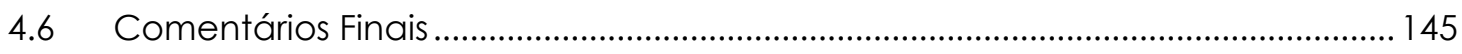

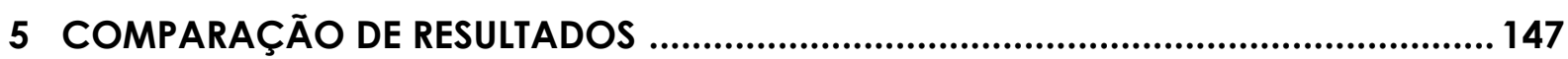

5.1 Comparação entre os valores da Força de Ruptura ao Cisalhamento na Ligação Viga-Pilar - ABNT NBR 8800, Análise Experimental e Numérica.......................... 147

5.2 Comparação Análise experimental versus Análise numérica............................... 149

5.3 Comparação com o trabalho de Silva (2006) .......................................................... 150

5.4 Comparação com o trabalho de Prion (1994) .......................................................... 151

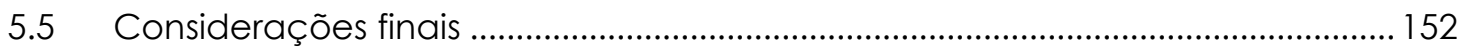

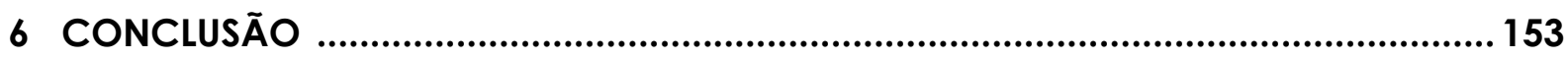

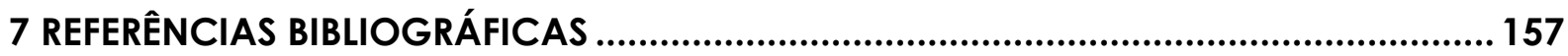

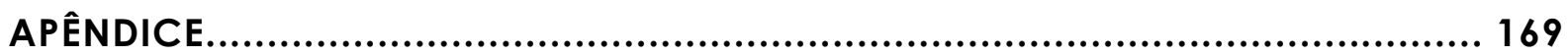





\section{1}

\section{Introdução}

Neste capítulo são apresentadas uma breve introdução ao assunto deste trabalho, a motivação para o seu desenvolvimento, assim como a justificativa, os objetivos, a metodologia e a forma de organização dos capítulos desta dissertação.

\subsection{Apresentação}

As estruturas mistas de aço e concreto surgiram no século passado. Segundo Viest et al. (1997) apud Bianchi (2002), as primeiras construções mistas datam de 1894 nos Estados Unidos, quando uma ponte e um edifício foram construídos usando vigas de aço revestidas com concreto, como alternativa de proteção ao fogo e à corrosão dos elementos estruturais de aço. A posterior intensificação do uso deveu-se ao grande número de edifícios altos construídos nas décadas de 1920 e 1930, entretanto, com sua finalidade ainda atrelada à proteção contra o fogo e a corrosão conferida pelo concreto.

No Brasil, as estruturas mistas só foram normalizadas em 1986 pela ABNT NBR 8800 (1986) - Projeto e Execução de Estruturas de Aço de Edifícios, contemplando somente os elementos mistos fletidos (vigas mistas). Atualmente a nova ABNT NBR 8800 (2008) já trata com mais profundidade o assunto, abordando vigas, pilares, lajes e ligações mistas. 
Para que haja resistência frente às forças atuantes, a interação entre aço e concreto nos pilares mistos deve ser garantida. Para isso, as tensões de aderência na interface açoconcreto não devem ser excedidas. Caso isto aconteça, é necessária a utilização de conectores de cisalhamento para evitar o deslocamento relativo entre os dois materiais obtendo-se, dessa forma, a atuação conjunta entre aço e concreto.

A necessidade de uma maior compreensão do comportamento dos conectores de cisalhamento para a ligação aço-concreto em pilares mistos é essencial para o conhecimento dos aspectos estruturais que os envolvem, contribuindo para a difusão do uso das estruturas mistas de aço-concreto.

\subsection{Motivação da pesquisa}

Os pilares mistos preenchidos apresentam ótimas características estruturais e construtivas. Entretanto, alguns assuntos relacionados ao comportamento estrutural, como as ligações viga-pilar preenchido e o mecanismo de transferência de esforços do pavimento para os pilares, ainda merecem atenção especial.

Príon e Mclellan (1994) estudaram um tipo de ligação viga-pilar misto preenchido e que apresenta bons resultados de resistência e rigidez. No Brasil esse mesmo tipo de ligação foi estudada por De Nardin (2004), Silva (2006), entre outros. A ligação consiste de barras rosqueadas que transpassam o pilar misto preenchido e funcionam como parafusos passantes. De Nardin (2004) estudou a questão da ligação viga-pilar preenchido, principalmente no que se refere ao seu comportamento à flexão. Silva (2006) investigou o papel dos conectores de cisalhamento nas ligações aço-concreto em pilares mistos preenchidos, ensaiados representando o elemento isolado e a ligação viga-pilar. Os resultados dos ensaios em elementos isolados mostraram uma efetiva contribuição dos conectores na transferência de forças entre o perfil de aço e o concreto do núcleo. Nos 
elementos de ligação, entretanto, a contribuição dos conectores não chegou a ser mobilizada já que houve o escoamento dos parafusos da ligação por efeito da flexão, indicando serem necessários estudos complementares para melhor avaliar os mecanismos de transferência de forças neste caso. Silva (2006) abordou em seu trabalho a questão da aderência aço-concreto em pilares mistos preenchidos e a contribuição dos conectores de cisalhamento, através de ensaios do tipo push out. Farias (2007) investigou as ligações viga de aço - pilar misto preenchido avaliando, sobretudo, a contribuição da laje na transferência de forças do pavimento para o pilar.

Dando continuidade às pesquisas citadas acima, este trabalho enfoca o estudo da transferência de forças de cisalhamento na ligação entre pilares mistos preenchidos e vigas de aço utilizando barras redondas rosqueadas. Desse modo, acredita-se contribuir para a elucidação das questões relativas ao comportamento das ligações envolvendo pilares mistos preenchidos e vigas de aço, e com isso, tornar sua utilização mais freqüente, permitindo a incorporação das vantagens inerentes ao sistema construtivo misto.

Espera-se que os resultados deste trabalho contribuam para a divulgação e ampliação da utilização de estruturas mistas no Brasil, quer seja em conjunto com estruturas de concreto moldadas no local ou pré-moldadas, visando a flexibilização e a modernização dos processos construtivos.

\subsection{Justificativa}

A justificativa principal deste trabalho reside na necessidade de buscar soluções para uma das principais barreiras à utilização de pilares mistos preenchidos: a ligação de tais pilares com os elementos do sistema de piso (vigas e lajes). Para isso, torna-se necessário desenvolver e propor dispositivos de ligação aplicáveis aos pilares mistos preenchidos. Os avanços nessa questão certamente trarão contribuições em direção à modernização dos 
sistemas estruturais e construtivos, levando à utilização mais racional e econômica dos materiais aço e concreto. Na realidade, há um grande espaço para o estudo e aproveitamento de estruturas mistas - incluindo a associação de elementos mistos com elementos de concreto armado ou de aço - que reúnam o melhor de cada material utilizado.

No que se refere à união entre os elementos viga e pilar, é importante o desenvolvimento de dispositivos de ligação de fácil execução, de baixo custo e que sejam eficientes do ponto de vista estrutural.

\subsection{Objetivos}

O objetivo principal deste trabalho é investigar as ligações viga de aço - pilar misto preenchido no tocante à transferência de forças de cisalhamento do pavimento para o pilar por meio de análise experimental e análise numérica.

Para a melhor compreensão desses mecanismos, foram investigados o papel de dois tipos de conectores de cisalhamento: os tipo pino com cabeça e as cantoneiras. Será comparado o comportamento das ligações quando há nos pilares conectores de cisalhamento com uma ligação de referência, que contará apenas com a aderência natural aço-concreto para efetivar essa transferência.

\subsection{Organização da dissertação}

A dissertação foi organizada em sete capítulos. Neste primeiro capítulo apresenta-se a motivação desta pesquisa situando-a dentro dos demais projetos dessa linha de pesquisa 
em desenvolvimento no Departamento de Estruturas da Escola de Engenharia de São Carlos (EESC), as justificativas e objetivos.

O capítulo 2, intitulado "Estado da Arte", foi elaborado a partir de revisão bibliográfica realizando uma síntese dos assuntos mais relevante dentro do contexto deste projeto de mestrado, no que diz respeito aos pilares mistos preenchidos, as ligações vigapilar e a transferência de esforços de cisalhamento, fornecida pelos conectores e barras rosqueadas.

No capítulo 3, Análise experimental, é apresentado todo o programa experimental desenvolvido, descrevendo os ensaios realizados, a instrumentação e os materiais adotados. Neste capítulo, apresenta-se também uma discussão dos resultados experimentais encontrados.

A análise numérica foi desenvolvida no capítulo 4. Neste foi realizado um resumo a respeito de modelagem numérica, especialmente modelagem vitlizando o pacote computacional DIANA®. Apresenta-se também o modelo estudado, as propriedades dos materiais, os elementos adotados e os resultados obtidos.

No capítulo 5 apresenta-se as recomendações de dimensionamento de acordo com a ABNT NBR 8800:2008. E são feitas comparações entre os resultados dessa norma com os resultados experimentais e resultados numéricos. Foi desenvolvido ainda neste capítulo um breve estudo comparativo entre os resultados deste projeto de pesquisa com outras pesquisas realizadas nessa mesma linha.

No capítulo 6 são reunidas as conclusões realizadas ao final de cada capítulo de forma objetiva.

E por fim, as referências bibliográficas no capítulo 7. 



\section{Estado da Arte}

Neste capítulo, intitulado estado da arte, é apresentada a revisão bibliográfica dentro dos objetivos deste projeto, fazendo inicialmente uma abordagem sobre pilares mistos preenchidos no que diz respeito a conceitos, tipologias, vantagens, interação açoconcreto, efeito de confinamento e comportamento estrutural, enfocando o dimensionamento segundo a ABNT NBR 8800:2008.

Em seguida aborda-se a problemática das ligações entre pilares mistos e vigas, ressaltando conceituação, tipologia, dimensionamento de ligações com barras redondas rosqueadas de acordo com a ABNT NBR 8800:2008. Discute-se também a respeito de alguns trabalhos nessa área.

\subsection{Pilares Mistos}

No projeto de sistemas mistos aço-concreto, o concreto e o aço devem trabalhar em conjunto para que a combinação de seus comportamentos isolados satisfaça todos os requisitos quanto à resistência, à rigidez e à estabilidade do conjunto. De forma simplificada, o tubo de aço é responsável por resistir às ações provenientes da fase construtiva e do peso próprio da estrutura, pois, nesta etapa o tubo ainda não foi preenchido com concreto. Após 
o preenchimento e o endurecimento do concreto, este passa a trabalhar em conjunto com o tubo de aço resistindo às ações de serviço atuantes na estrutura (Farias, 2008).

Os pilares mistos são elementos estruturais formados a partir da combinação entre um perfil de aço e o concreto, em que as propriedades dos dois materiais contribuem para o comportamento como um todo, uma vez que o aço possui bom comportamento à tração, e o concreto à compressão, minimizando os problemas referentes a esses materiais: resistência à tração do concreto e instabilidade do perfil de aço. O concreto no interior do tubo minimiza os problemas de instabilidade do perfil de aço, já o perfil pode aumentar a resistência do concreto devido ao efeito do confinamento.

O uso do pilar misto preenchido começou no final do século 19, em construções de grande porte e em pontes. Esse elemento estrutural torna-se mais atraente em locais onde há a ocorrência de abalos sísmicos e impactos de tráfego, devido às suas propriedades de resistência, ductilidade e capacidade de absorver energia. Assim sendo, nos países asiáticos, como o Japão e em alguns países da Europa e na Austrália, a quantidade de pesquisas a respeito dos pilares mistos preenchidos é muito acentuada. De acordo com Uy (1998) apud Farias (2008) o principal desafio desses países é tornar o sistema competitivo em relação às estruturas de concreto armado e estruturas metálicas de forma a viabilizar o seu uso em estruturas convencionais. O crescimento e a popularização desse sistema se devem à rapidez de execução e à minimização do custo referente à não utilização de fôrmas, pois nesses países, o custo da madeira atinge valores bastante elevados.

\subsubsection{Tipologia}

De acordo com a posição que o concreto ocupa na seção transversal mista, os pilares mistos podem ser classificados como revestidos, parcialmente revestidos, preenchidos ou ainda como "battened". 
Os pilares mistos totalmente revestidos são aqueles em que o concreto envolve totalmente o perfil de aço (Figura 2.1). O envolvimento do concreto estrutural sobre o perfil de aço promove um aumento na capacidade resistente da seção de aço, minimizando os fenômenos de flambagem local e global do perfil de aço; e ainda contribui para a proteção ao fogo e à corrosão. Uma desvantagem da utilização desse tipo de pilar é que a sua execução se torna trabalhosa, pois exige utilização de fôrmas durante a concretagem e cuidados no posicionamento e fixação dos perfis e barras de armadura. As armaduras são necessárias para combater o fendilhamento na capa de (Oliveira, 2008).

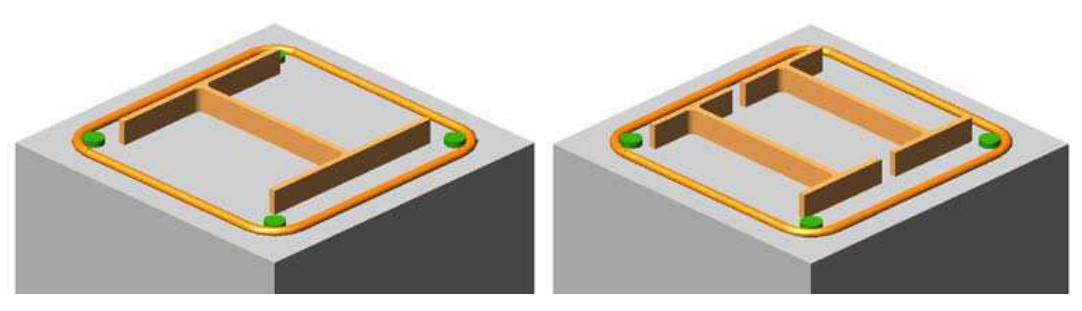

Figura 2.1. Pilar misto revestido (Oliveira, 2008).

Nos pilares mistos parcialmente revestidos o concreto envolve parcialmente o(os) perfil(is) de aço (Figura 2.2).

Os pilares tipo "battened" são formados a partir da junção de dois perfis tipo U, ligados por talas e preenchidos de concreto, sendo sua utilização restringida a investigações experimentais, haja vista que a instrumentação do concreto se torna mais fácil. A Figura 2.3 ilustra esse tipo de pilar misto. 


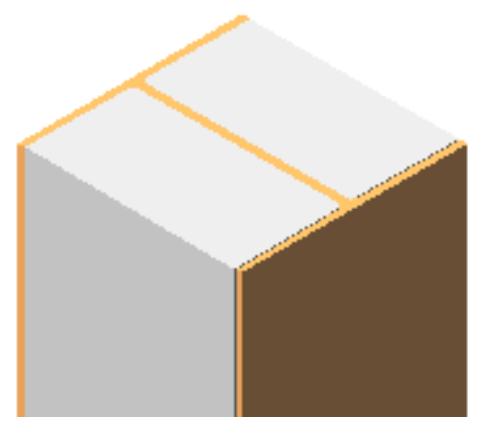

Figura 2.2. Pilar misto parcialmente revestido (Oliveira, 2008).

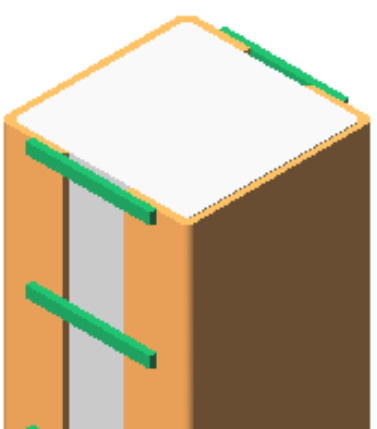

Figura 2.3. Pilar misto tipo battened (Oliveira, 2008).

Os pilares mistos preenchidos são elementos estruturais formados pela associação de um perfil de aço, podendo ser tubular retangular ou circular ou pela junção de dois ou mais perfis, e que posteriormente é preenchido com concreto estrutural de resistência à compressão igual ou superior a 20 MPa. Armaduras de aço na seção de concreto podem ser utilizadas de forma a contribuir na capacidade resistente do pilar misto, entretanto não são necessárias devido à posição que o tubo de aço ocupa na seção.

A forma do perfil tubular a ser utilizado para a confecção dos pilares mistos preenchidos pode ser circular ou retangular, confeccionados por processo de extrusão ou combinação de perfis por soldagem de dois ou mais perfis.

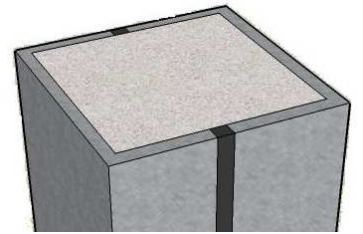

(a)

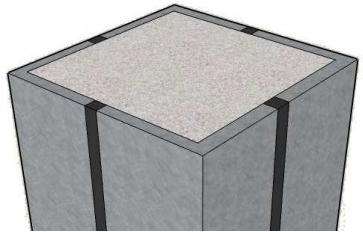

(b)

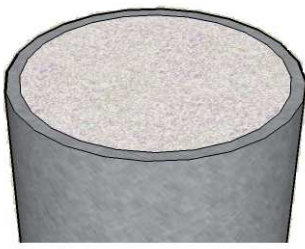

(c)

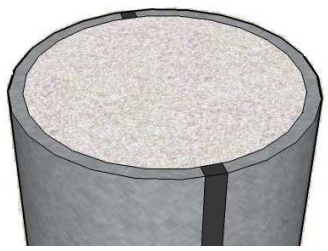

(d)

Figura 2.4. Tipo de seções transversais pilares mistos preenchidos. (a) Pilar misto de seção quadrada, soldagem de 2 perfis "U". (b) Pilar misto seção quadrada, soldagem de 4 cantoneiras. (c) Pilar misto de seção circular, processo de extrusão. (d) Pilar misto seção circular, chapa com costura (soldagem longitudinal). 
As características dos dois materiais constituintes contribuem para o comportamento do elemento como um todo, de forma que são exploradas as vantagens de cada material, minimizando suas desvantagens.

\subsubsection{Vantagens}

As estruturas de aço oferecem vantagens na montagem, podendo ser executadas em quaisquer condições de tempo, e possibilitam economia nas fundações, devido à redução do peso da estrutura, além de permitir um canteiro de obras mais limpo e acessível. O concreto apresenta a vantagem de compor seções mais rígidas e de ser mais resistente ao fogo e à corrosão, em comparação com o aço. Entretanto, quando se trata de estruturas mistas aço-concreto, pode-se dizer que o objetivo é aproveitar ao máximo as vantagens que cada um dos materiais pode proporcionar.

De acordo com Bianchi (2002) e Farias (2008), podem-se listar diversas vantagens que as estruturas mistas propiciam quando comparadas às:

- Estruturas de aço:

- Aumento da estabilidade lateral da edificação;

- Aumento da proteção do aço contra incêndio;

- Redução do consumo de aço estrutural.

- Estruturas de concreto:

- Maior velocidade de execução;

- Racionalização da construção;

- Eliminação ou redução de formas e escoramentos; 
- Aumento da precisão dimensional da construção, resultando em redução dos custos dos revestimentos, bem como das correções de prumo e de nível;

- Simplificação geral de toda a construção, levando a uma redução do tempo de execução;

- Redução global de peso próprio, resultando em economia de fundação.

Outras vantagens que o pilar misto preenchido possui que o torna interessante para diversas aplicações da Engenharia de Estruturas são:

- A capacidade resistente à compressão;

- A alta capacidade de absorver energia (alta tenacidade);

- Comportamento dúctil;

- Rapidez de execução resultando em um processo construtivo racionalizado e com baixo nível de desperdícios;

- Aumento da resistência do concreto devido ao efeito de confinamento provocado pelo perfil de aço.

\subsubsection{Interação Aço-Concreto}

Nos elementos mistos é necessário que haja um trabalho conjunto dos materiais, aço e concreto, permitindo que ocorra transferência de tensões de cisalhamento. Esses esforços de cisalhamento podem ser transferidos do aço para o concreto por três mecanismos de aderência: por adesão, por atrito e mecânica. 
A ordem de grandeza da parcela de adesão é desprezível quando comparada às parcelas de atrito e mecânica, pois tais parcelas estão interligadas e dependem das propriedades mecânicas da interface aço-concreto.

A Figura 2.5 ilustra essas três parcelas de aderência por meio da curva tensão de cisalhamento versus deslocamento relativo.

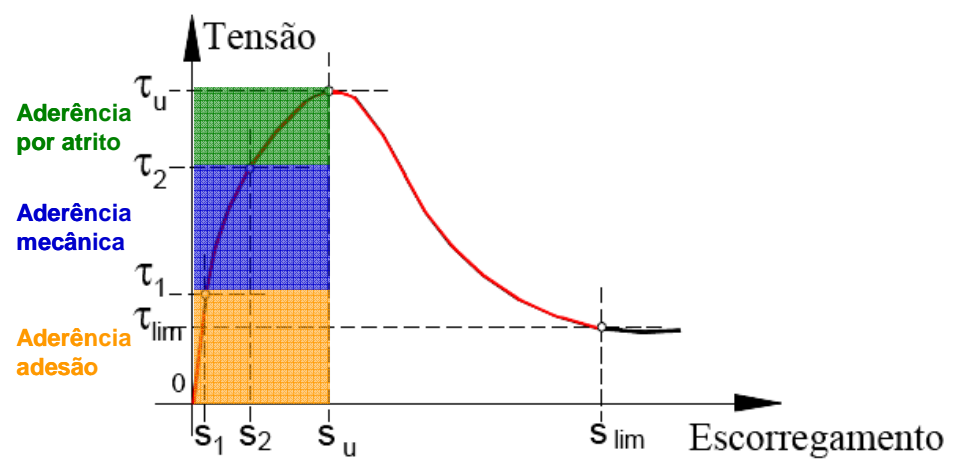

Figura 2.5. Curva tensão de cisalhamento vs escorregamento.

Analisando a curva da Figura 2.5, observa-se que a parcela correspondente à aderência por adesão é representada pelo trecho mais inclinado da curva. O trecho inclinado posterior à adesão está relacionado com a aderência mecânica e, o último trecho ascendente, à aderência por atrito. Se o trecho pós-pico da curva for horizontal ou descendente, a aderência foi destruída e há deslizamento relativo entre o aço e o concreto.

\section{A. Aderência por adesão}

A adesão corresponde à aderência química que surge durante as reações de pega do cimento, em decorrência das ligações físico-químicas na interface aço-concreto. Essa parcela é mobilizada nos estágios iniciais de carregamento, quando os deslocamentos são 
pequenos e as tensões atingem valores não superiores a 0,1 MPa, mas, é destruída assim que se inicia o deslocamento relativo entre os dois materiais. A aderência por adesão é considerada um mecanismo de comportamento elasto-frágil que está diretamente relacionado à rugosidade e à limpeza da superfície de contato. A Figura 2.6 ilustra a mobilização da aderência por adesão.

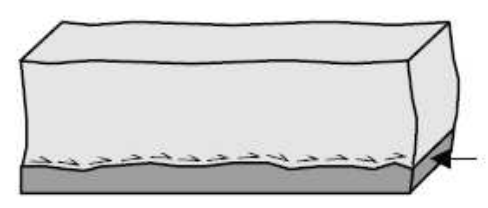

Figura 2.6. Mecanismo de transferência da aderência por adesão. (Johansson, 2002).

De acordo com Roeder et al. (1999) apud Oliveira (2008), nos pilares mistos preenchidos a transferência de tensões entre concreto e aço via adesão depende da expansão radial do concreto, causada pela pressão de bombeamento em estado fresco e pela retração do concreto. Para que haja adesão aço-concreto, a pressão de bombeamento tem que permanecer na interface após a ocorrência do efeito de retração; isso requer altas pressões laterais, que dificilmente ocorrem na prática, assim, a retração será dominante e a adesão será reduzida consideravelmente.

Resultados de Roeder et al. (1999) mostraram que pilares mistos preenchidos de seção circular apresentam maior tensão de aderência que aqueles de seção quadrada e que a aderência parece não ter relação com a resistência do concreto, e diminui com o aumento da relação entre diâmetro e espessura.

\section{B.Aderência mecânica}

A aderência mecânica está relacionada com o engrenamento mecânico entre as irregularidades do aço e o núcleo de concreto. Virdi \& Dowling (1980) apud Silva (2006) 
afirmam que a aderência mecânica tem ligação direta com o grau de rugosidade da superfície interna do tubo de aço, e que a ruptura desse mecanismo ocorre para uma deformação específica do concreto da interface de aproximadamente 3,5\%.

Segundo Silva (2006), a parcela mecânica ganha relevância apenas quando as superfícies do aço e do concreto estão em contato, pois com o aumento da força aplicada, há tendência de deslocamento relativo entre os materiais e de diminuição desta parcela. Entretanto, como o tubo confina o núcleo de concreto, esse efeito passivo impede a separação entre os materiais e surgem tensões normais resistentes ao escorregamento. Silva (2006) conclui ainda que essa parcela de aderência mecânica pode ser considerada um mecanismo parcial de atrito.

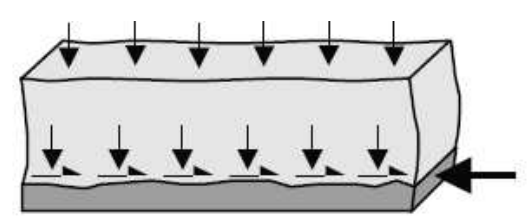

Figura 2.7. Mecanismo de transferência aderência mecânica. (Johansson, 2002).

O adensamento do concreto tem influência maior na parcela de aderência mecânica do que o fenômeno de retração, portanto, devem ser realizados bons adensamentos de forma a conduzir a um maior engrenamento do aço com o concreto e, consequentemente, aumentar a aderência mecânica entre ambos.

\section{C.Aderência por atrito}

Assim como a parcela de aderência mecânica, a aderência por atrito também é manifestada quando há tendência de deslocamento relativo entre os materiais. A principal característica deste mecanismo é a proporcionalidade da transferência da força aplicada 
em relação à força normal à superfície de atrito que, por sua vez, está relacionado ao grau de rugosidade da superfície de aço e à condição da interface.

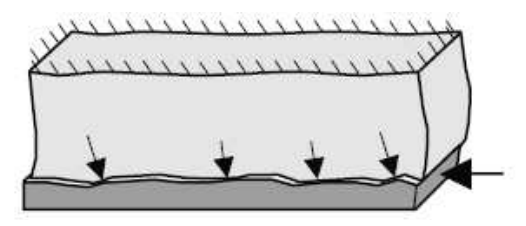

Figura 2.8. Mecanismo de transferência aderência por atrito. (Johansson, 2002).

Segundo Queiroz et al. (2001), em estruturas mistas submetidas a baixos valores de carga, a maior parte do cisalhamento longitudinal é desenvolvida por aderência química entre a pasta de cimento e a superfície de aço. No entanto, quando o carregamento é aumentado, ocorre o rompimento da parcela de aderência química (aderência por adesão) e, uma vez rompida esta parcela, não pode ser mais restaurada. Os valores de carga correspondentes à ruptura da adesão química são bastante variáveis, dependendo de fatores como: relação água-cimento, desenvolvimento de fissuras, retração do concreto, tensões devidas à variação de temperatura, falhas locais de contato entre o concreto e o aço. Dessa forma, pode ser necessário o uso de conectores mecânicos de cisalhamento para transmitir as forças de cisalhamento na interface aço-concreto, podendo ser conectores tipo pino com cabeça, cantoneiras ou outro dispositivo que ofereça resistência ao deslizamento.

De um modo geral, a rigidez dos conectores está associada às características da sua resposta à ação do fluxo de cisalhamento gerado na superfície de contato entre o perfil de aço e o concreto. Tal rigidez pode ser expressa pela relação entre a força no conector e o deslocamento relativo entre os elementos. Quando essa relação for grande, o conector é considerado rígido; quando for pequena, o conector é considerado flexível (Figura 2.9). 


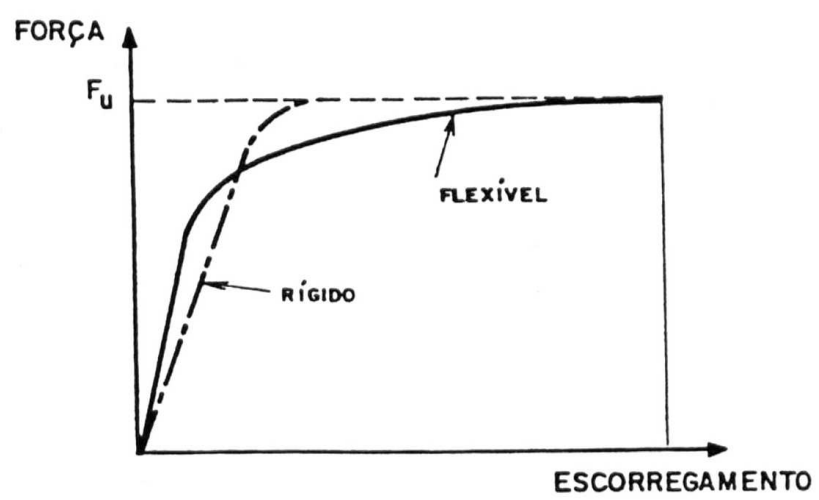

Figura 2.9. Diagrama força $x$ deslocamento relativo do concreto. (Bianchi, 2002).

Quando submetido a um carregamento crescente, um conector flexível, após atingir sua resistência máxima, pode continuar a deformar-se sem alcançar a ruptura, permitindo que conectores vizinhos sejam mobilizados e absorvam maior força cortante, atingindo, também, sua capacidade resistente; isso torna o sistema de transferência mais eficiente. De acordo com Bianchi (2002), essa característica de comportamento permite espaçar igualmente esse tipo de conector, sem diminuir a resistência máxima da conexão açoconcreto.

Já os conectores rígidos têm comportamento frágil, no qual, uma vez atingida a capacidade máxima dos conectores mais solicitados, não ocorre redistribuição de esforços. Sendo assim, a discussão do fenômeno de redistribuição só tem relevância no contexto da utilização de conectores flexíveis.

Dos diversos tipos de conectores de cisalhamento disponíveis, o mais utilizado é o tipo pino com cabeça, cuja resistência última está relacionada diretamente a fatores como: comprimento de embutimento no concreto, resistência ao cisalhamento do concreto, espessura da chapa de base (McMackin, 1973).

Resultados de vários estudos permitiram afirmar que, nos pilares mistos predominantemente comprimidos (esforço cortante relativamente pequeno), podem-se 
dispensar, na grande maioria dos casos, os conectores de cisalhamento. Nesse caso, é admitido que a resistência da ligação aço-concreto é suficiente para garantir a interação completa entre os dois materiais.

Apesar de não existir procedimento padrão para o cálculo da tensão de cisalhamento transferida na interface, este pode se basear em um valor médio expresso pela razão entre a componente da força normal no concreto $\left(N_{c, s d}\right)$ e a área de transferência na interface, que corresponde ao produto do perímetro transversal (Ua) pelo comprimento $\left(\mathrm{l}_{\mathrm{v}}\right)$, conforme ilustrado na Figura 2.10.

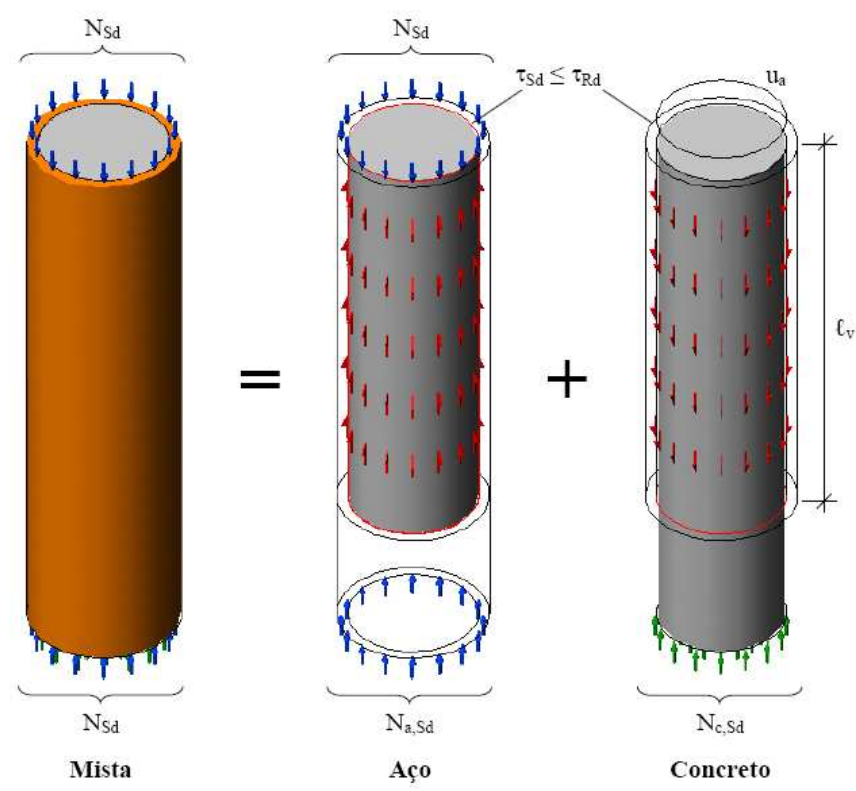

Figura 2.10. Componentes das ações de cálculo e propriedades geométricas para o cálculo da tensão de cisalhamento na interface. Fonte: Johansson (2003) apud Oliveira (2008).

Desse modo, a tensão de cisalhamento é dada por:

$$
\tau_{S d}=\frac{N_{c, S d}}{U_{a} l_{v}}
$$

Conforme Johansson (2003), nos pilares preenchidos a tensão de cisalhamento $\tau_{S d}$ deve ser menor que a tensão resistente de cálculo $\left(\tau_{R d}\right)$, estimada em 0,4 MPa. Se 
$\tau_{\mathrm{Sd}} \geq \tau_{\mathrm{Rd}}$, a transferência das forças de cisalhamento deve ser feita por meio de conectores de cisalhamentos.

Silva (2006) abordou, em seu trabalho, o estudo da aderência em pilares mistos preenchidos, por meio de ensaios de arrancamento utilizando três tipos de modelos de pilar preenchido: modelo simples (CFT-S, sem conector de cisalhamento, Figura 2.11a), modelo com conector tipo pino com cabeça (CFT-B, Figura $2.11 \mathrm{~b}$ ) e modelo com conector tipo cantoneira (CFT-A, Figura 2.11c), na interface aço-concreto. Os pilares preenchidos estudados por Silva (2006) foram fabricados a partir da união de dois perfis tipo "U" de $200 \times 100 \times 6,3 \mathrm{~mm}$, formados a frio, em aço SAE 1020, componde seções quadradas com $200 \mathrm{~mm}$ de lado.

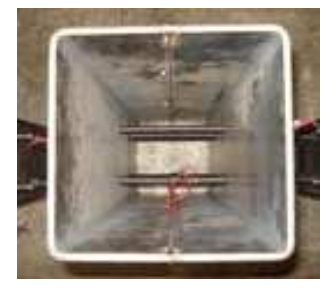

(a)

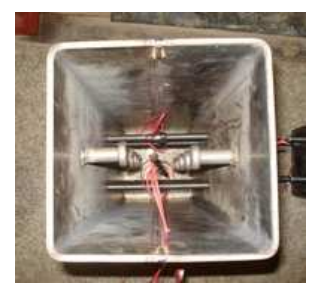

(b)

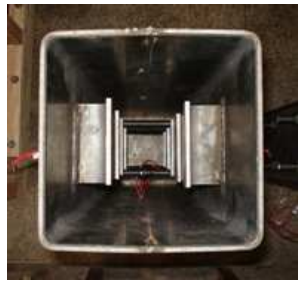

(c)

Figura 2.11. Vista interna dos modelos físicos estudados por Silva (2006).

Nesse estudo, a principal variável foi a presença de conectores de cisalhamento utilizados para promover a transferência de tensões de cisalhamento do núcleo de concreto para o perfil de aço. Dessa maneira, foi avaliada a contribuição dos conectores tipo pino com cabeça e tipo cantoneira ( $\mathrm{L} 50 \times 6,3 \mathrm{~mm}$ ) nos mecanismos de transferência de forças na interface aço-concreto.

Os resultados apresentados por Silva (2006) e expressos na Figura 2.12 mostram as curvas obtidas nos ensaios dos três modelos físicos. A partir destas curvas, Silva (2006) concluiu que todos os modelos ensaiados apresentaram grande rigidez da interface açoconcreto nos primeiros estágios de carregamento, antes de a força máxima resistente ser 
alcançada. Atingida a força máxima resistente, o modelo com conector tipo pino com cabeça (CFT-SB) apresentou um decréscimo de força aplicada, passando de $650 \mathrm{kN}$ para o valor de $125 \mathrm{kN}$ no trecho pós-pico. Desse ponto até o fim do ensaio, os deslocamentos aumentaram sob força aproximadamente constante; isso evidencia o deslocamento do núcleo de concreto em relação ao tubo de aço e uma resistência residual atribuída às condições de rugosidade da interface aço-concreto. No modelo sem conector de cisalhamento (CFT-S) a adesão ocorre nos primeiros estágios de carregamento, sendo rompida quando se inicia o escorregamento relativo entre o aço e o concreto, que correspondeu a $42 \mathrm{kN}$ de força aplicada. A partir da ruptura da adesão, a resistência na interface é, então, garantida pela aderência mecânica e por atrito.

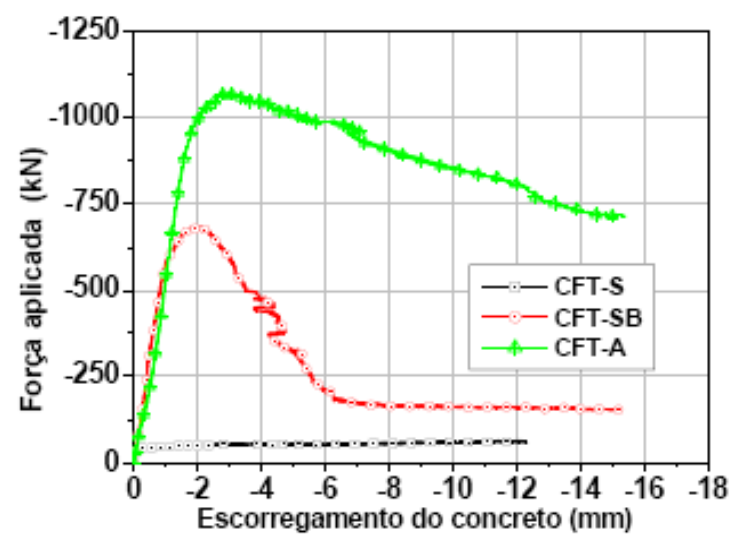

Figura 2.12. Curva força aplicada vs. escorregamento do concreto. Silva (2006).

Quando se compara os três modelos estudados por Silva (2006), comprova-se a eficiência dos conectores e das cantoneiras como dispositivos de transferência de forças do núcleo de concreto para o tubo de aço. Com relação à distribuição de forças ao longo da interface e deslizamento do núcleo de concreto em relação ao tubo de aço, foram encontrados os seguintes valores: 
Tabela 2.1. Resultados Silva (2006)

\begin{tabular}{ccc}
\hline Modelo & Força ao longo da interface (MPa) & Deslizamento do Núcleo de Concreto (mm) \\
\hline CFT-S & 0,22 & 16,0 \\
CFT-SB & 2,43 & 1,38 \\
CFT-A & 3,81 & 1,27 \\
\hline
\end{tabular}

Verifica-se também que no modelo com cantoneiras, a área de influência destes elementos mobiliza um volume maior de concreto que aquele mobilizado no modelo com pinos com cabeça e resulta em rotações das cantoneiras e distorções do tubo de aço. Tais rotações e distorções resultam numa parcela significativa do mecanismo de transferência de tensões de cisalhamento e no considerável aumento da força máxima aplicada. Além deste efeito no trecho pré-pico, a presença das cantoneiras também modifica o comportamento pós-pico, aumentando a resistência residual da interface em relação aos demais modelos ensaiados. Dessa forma, conclui-se que ambos os tipos de conectores avaliados limitam consideravelmente a deslocabilidade do núcleo de concreto.

\subsubsection{Efeito de confinamento}

Shams \& Saadeghvaziri (1997) descreveram o comportamento do núcleo de concreto do pilar misto preenchido quando solicitado por carregamento axial, quanto ao efeito de confinamento, em três etapas: nos primeiros estágios de carregamento do pilar misto preenchido, o concreto apresenta coeficiente de Poisson de 0,2 e o aço de 0,3; isto promove uma pequena expansão lateral do concreto. Aumentando o carregamento aplicado, quando inicia a fissuração do concreto, esse apresenta deformações significativas e que ultrapassam seu limite plástico e, assim, o coeficiente de Poisson atinge um valor em torno de 0,5 , resultando em considerável expansão lateral do concreto. Como conseqüência da tentativa de expansão do concreto, surge pressão interna aplicada ao 
tubo de aço pelo concreto. A partir desse instante, o aço fica submetido a um estado biaxial de tensões, e o concreto, a um estado triaxial, e tais condições são responsáveis pelo aumento da capacidade resistente do conjunto aço-concreto até que seja atingida a capacidade resistente (última etapa).

Sakino et al. (2004), concluiraam que, para relações D/† (diâmetro/espessura) altas e relações $f_{y k} / f_{c k}$ (resistência ao escamento do aço/resistência à compreensão do concreto) baixas, o efeito do confinamento tende a ser menor. Tais pesquisadores observaram também que pilares mistos preenchidos de seção circular apresentam aumento de capacidade resistente em função do efeito de confinamento, enquanto que nos estudos com pilares de seção retangular e quadrada, os resultados não são significativos.

Segundo Fujimoto et al. (2004) apud Farias (2008), os pilares mistos de seção retangular apresentam perda de ductilidade após atingir a força máxima e a forma da seção proporciona uma diminuição do efeito de confinamento, resultando em um desempenho inferior da aderência na interface aço-concreto.

Oliveira (2008) estudou o comportamento dos pilares mistos preenchidos de seção circular, avaliando a influência da resistência à compressão do concreto $\left(f_{c}\right)$, a relação (L/D), da espessura do tubo de aço (t) e da forma de introdução do carregamento, se no núcleo de concreto ou na seção mista do pilar. Foram realizados 64 ensaios experimentais em pilares mistos preenchidos, submetidos à força de compressão centrada. Os resultados de capacidade resistente obtidos foram avaliados e comparados com os procedimentos normativos estrangeiros e a ABNT NBR 8800:2008. Após os ensaios, Oliveira (2008) observou que o modo de falha depende basicamente, da esbeltez global e local dos pilares, concluindo desse modo que:

- Os pilares com relação $L / D=3$ apresentaram ruptura por esmagamento do núcleo de concreto, agravado pela flambagem local do elemento após ser atingida a resistência ao escoamento do aço; ou, ruptura por esmagamento do concreto, com 
os efeitos da flambagem local menos aparentes devido à maior resistência do tubo a este efeito. Estes apresentaram comportamento pós-pico com alto grau de ductilidade, ou seja, elevados valores de deformação axial sem perda brusca da capacidade resistente.

- Os pilares com relações $L / D=5, L / D=7$ e $L / D=10$, dois modos de falha foram observados: os pilares com espessura de $3,35 \mathrm{~mm}$ apresentaram cisalhamento do núcleo de concreto e os pilares com tubo de $6 \mathrm{~mm}$ de espessura atingiram a ruína por uma combinação entre esmagamento do concreto e instabilidade global.

- A redução na espessura do tubo de aço resultou em ductilidade considerável apenas para os pilares preenchidos com concretos de resistência menor (30MPa e $60 \mathrm{MPa})$. Isso é atribuído à menor pressão lateral de confinamento do tubo de $3,35 \mathrm{~mm}$.

- Com relação à forma de introdução da força, nos pilares cuja força é aplicada somente no núcleo de concreto ocorreu acréscimo na capacidade resistente, quando comparada aos pilares com força aplicada na seção mista.
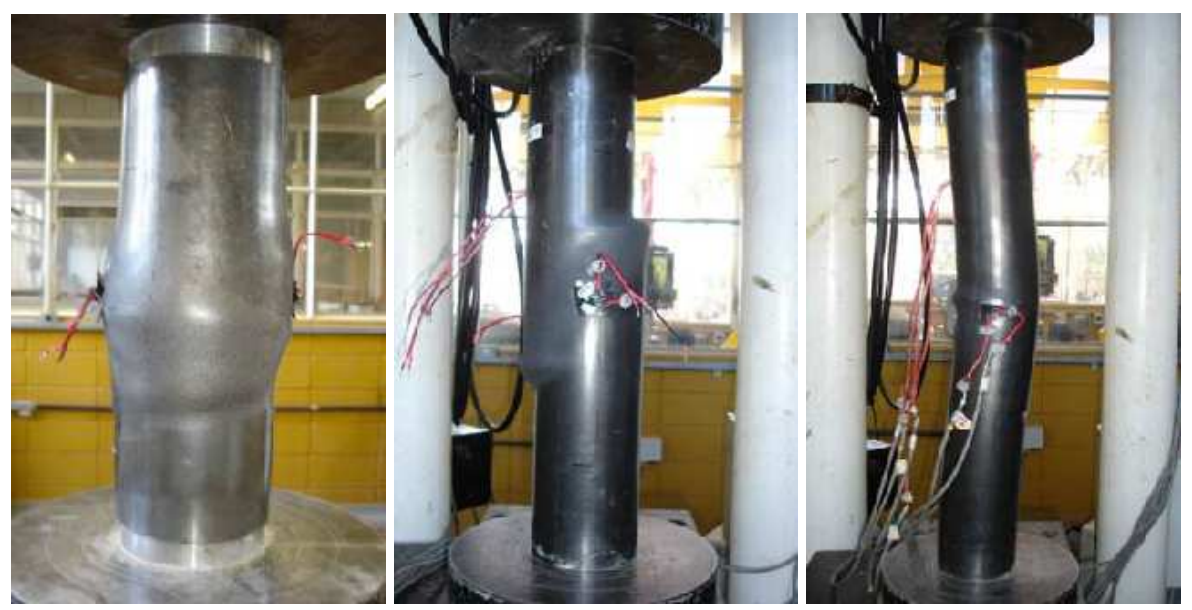

Figura 2.13. Modos de ruptura nos pilares mistos preenchidos estudados por Oliveira (2008). Fonte: Oliveira (2008). 


\subsubsection{Comportamento estrutural}

O comportamento estrutural dos pilares mistos preenchidos é influenciado por fatores como: aderência aço-concreto, retração e fluência do concreto, flambagem local, tensões residuais do perfil de aço e efeito de confinamento.

São observados três modos de ruína nos pilares mistos preenchidos solicitados por força normal centrada: esmagamento do concreto, flambagem global do pilar misto preenchido e flambagem local do tubo de aço.

O modo de ruína é governado, de forma predominante, pela esbeltez do pilar. Para pilares curtos e medianamente esbeltos, a ruína pode ocorrer por escoamento do tubo de aço e/ou por esmagamento do concreto. Já para pilares esbeltos, a ruína ocorre, geralmente, por flambagem do tubo de aço, (Farias, 2008). Esse tipo de comportamento já havia sido observado nos estudos experimentais realizados por Shams \& Saadeghvaziri (1997) nos quais foram verificados dois tipos de ruína nos pilares preenchidos: flambagem do tubo de aço (pilares esbeltos) e esmagamento do concreto (pilares curtos). Fatores como esbeltez, espessura dos elementos e resistência dos componentes afetam a resistência e a ductilidade do pilar preenchido.

Huang et al. (2002), assim como Shams \& Saadeghvaziri (1997), concluíram que a esbeltez e a espessura do tubo de aço são os principais fatores que determinam tanto o modo de ruína como a capacidade resistente do pilar misto preenchido.

De acordo com Farias (2008), o processo construtivo do pilar misto preenchido requer que o tubo de aço tenha capacidade de resistir ao seu peso próprio e às ações provenientes da construção (peso próprio da laje, vigas e etc.) porque, nessa etapa, o tubo ainda não foi preenchido pelo concreto. O efeito do pré-carregamento no tubo de aço, antes do seu preenchimento com concreto, foi estudado experimentalmente por Han e Yao 
(2003). Esses pesquisadores observaram que o pré-carregamento no tubo de aço provoca um aumento de deformação e uma perda de resistência da ordem de $15 \%$ no pilar misto.

Durante o processo de preenchimento do tubo de aço, esse deve ser capaz de suportar pressões laterais provenientes do concreto em estado fresco. E, durante a vida útil, o conjunto aço-concreto deve suportar as ações de serviços e os efeitos de longa duração, como a deformação lenta (fluência) e a retração do concreto. A fluência do concreto causa redução das tensões no concreto e, consequentemente, acréscimo de tensões no tubo de aço.

A ductilidade dos pilares mistos está relacionada com a forma da seção transversal dos mesmos e com a resistência dos materiais envolvidos. Segundo Fujimoto et al. (2004), concreto de alta resistência em pilares mistos preenchidos leva à perda de ductilidade, mas, se tal concreto for combinado com aço de alta resistência, a ductilidade pode ser garantida. Já Liu et al. (2003) afirmam que, apesar de os materiais de alta resistência ocasionarem perda de ductilidade, ainda assim o comportamento quanto à ductilidade é satisfatório. Entretanto, Cederwall et al. (1990) confirmaram experimentalmente que apenas nos pilares esbeltos o concreto contribui para a ductilidade, e que o aço contribui de forma mais significativa para o aumento da ductilidade e que o uso de armaduras de aço no núcleo de concreto traz efeitos benéficos para a ductilidade do pilar misto.

\subsubsection{Dimensionamento dos Pilares Mistos Preenchidos de acordo com a ABNT NBR 8800:2008}

O método de dimensionamento para pilares mistos apresentado na ABNT NBR 8800:2008, tem como hipóteses básicas:

- A interação completa entre o aço e o concreto, ou seja, a não ocorrência de deslocamento relativo significativo entre os dois materiais; 
- As imperfeições iniciais são consistentes com aquelas adotadas para a determinação da resistência de barras de aço submetidas à compressão axial;

- A flambagem local do tubo de aço para força axial e momento fletor não pode ser um estado-limite último predominante.

O método simplificado de dimensionamento dos pilares mistos apresentado pela ABNT NBR 8800 se limita às seguintes aplicações:

- Os pilares mistos devem ter dupla simetria e seção transversal constante;

- O concreto utilizado deve possuir densidade normal;

- O fator de contribuição do aço, dado por $\delta=\frac{A_{a} f_{y d}}{N_{p l, R d}}$, deve estar no intervalo $0,2<\delta<0,9$. Se $\delta$ for igual ou inferior a 0,2 , o pilar deve ser dimensionado de acordo com a ABNT NBR 6118 como pilar de concreto e, se $\delta$ for igual ou superior a $0,9,0$ pilar deve ser dimensionado segundo a ABNT NBR 8800, como um pilar de aço.

- A esbeltez relativa do pilar deve ser inferior a 2,0;

- Seções preenchidas de concreto podem ser fabricadas sem qualquer armadura, exceto para algumas condições em situação de incêndio;

- A relação entre a altura e a largura das seções transversais mistas retangulares deve estar entre 0,2 e 5,0;

\section{A. Flambagem local dos elementos de aço}

As resistências de todos os materiais devem ser atingidas sem que ocorra flambagem local dos elementos componentes do perfil de aço da seção transversal. Dessa forma, não pode ser ultrapassada a relação $\frac{b_{i}}{t} \leq 2,26 \sqrt{\frac{E}{f_{y}}}$ (relação adotada para seção retangular), em 
que bi é a maior dimensão paralela a um eixo de simetria da seção tubular retangular, $t$ a espessura, $f_{y}$ a resistência ao escoamento do aço e $E$ o módulo de elasticidade do aço.

\section{B. Cisalhamento nas superfícies de contato entre o perfil de aço e o concreto}

A norma considera que as regiões de introdução de cargas são aquelas onde ocorrem variações localizadas dos esforços solicitantes devidas as ligações de pilar com vigas, ou aquelas onde ocorre interrupção da armadura longitudinal, como em emendas do pilar ou em bases. Nessas regiões, deve-se evitar que ocorra escorregamento significativo na interface entre o concreto e o perfil de aço para garantir a transferência de tensões entre os dois materiais e evitar que a ruína ocorra de forma localizada em apenas um dos componentes. Para isso, a ABNT NBR 8800:2008 recomenda um comprimento de introdução de carga igual a duas vezes a menor dimensão da seção do pilar ou um terço da distância entre pontos de introdução de carga, o que for menor.

Deve ser observado também que nas regiões de ligação da viga com o pilar, as tensões de cisalhamento entre o aço e o concreto, determinadas por meio dos esforços solicitantes de cálculo (cortante e momento), não podem superar os valores de tensão de cisalhamento resistente de cálculo apresentados na Tabela 2.3.

Tabela 2.2 . Tensão de cisalhamento resistente de cálculo

\begin{tabular}{cc}
\hline Tipo de seção transversal do pilar misto & $\tau_{\mathrm{Rd}}(\mathbf{M P a})$ \\
\hline Seção tubular retangular preenchida com concreto & 0,40
\end{tabular}

Os esforços solicitantes, cortante e momento, para a situação em que a viga está ligada apenas ao perfil de aço do pilar são determinados pelas equações 2.2 e 2.3.

$$
V_{l, S d}=V_{S d}\left(1-\frac{N_{p l, a, R d}}{N_{p l, R d}}\right)
$$




$$
M_{\mathrm{l}, \mathrm{Sd}}=M_{S d}\left(1-\frac{M_{p l, a, R d}}{M_{p l, R d}}\right)
$$

Em que:

$\bigvee_{1, S d}$ é o esforço solicitante de cálculo;

$\mathrm{V}_{\mathrm{Sd}}$ é a força cortante solicitante de cálculo na ligação;

$\mathrm{N}_{\mathrm{pl}, \mathrm{a}, \mathrm{Rd}}$ é a força axial resistente de cálculo somente do perfil de aço à plastificação total definida no item 2.2.8;

$N_{p l, R d}$ é a força axial resistente de cálculo da seção transversal do pilar misto à plastificação total definida no item 2.2.8;

$M_{1, S d}$ é o momento fletor solicitante de cálculo;

$\mathrm{M}_{\mathrm{Sd}}$ é momento fletor solicitante de cálculo na ligação;

$M_{p l, a, R d}$ é a contribuição do perfil de aço para $M_{p l, R d}$;

$M_{\text {pl,Rd }}$ é o momento fletor resistente de plastificação de cálculo do pilar misto.

Se essas tensões forem excedidas, devem ser usados conectores de cisalhamento para resistir à totalidade dos efeitos de $V_{1, S d}$ e $M_{1, S d}$.

Os conectores de cisalhamento também devem ser utilizados nos trechos entre regiões de introdução de cargas, que são aqueles fora das regiões afetadas pela base, por emendas ou por ligações com vigas. A função dos conectores é garantir o fluxo de cisalhamento longitudinal entre o perfil de aço e o concreto, determinado com base nas forças cortantes solicitantes de cálculo, sempre que as tensões na interface ultrapassarem os 
valores da tensão de cisalhamento resistente de cálculo. O fluxo do cisalhamento pode ser determinado considerando o concreto não fissurado e comportamento elástico, levando em conta a sequência de construção e os efeitos de retração e fluência.

Quando o pilar for preenchido com concreto e a relação entre a força axial de compressão solicitante de cálculo no pilar e a força axial de compressão resistente de cálculo da seção transversal de plastificação total for superior a 0,3, não é necessário prever conectores nos trechos entre regiões de introdução de cargas.

\section{Força de compressão axial}

A força de compressão resistente de cálculo para pilares mistos axialmente comprimidos sujeitos à instabilidade por flexão é determinada pela equação 2.4, conforme a ABNT NBR 8800:2008.

De acordo com essa norma, a força axial de compressão resistente de cálculo à plastificação total $\left(N_{p l, R d}\right)$ deve ser calculada de acordo com o item P.4, e dada pela soma das forças axiais resistentes de cálculo de seus componentes: perfil de aço, concreto e armadura longitudinal:

$$
\mathrm{N}_{\mathrm{Rd}}=\chi \mathrm{N}_{\mathrm{pl}, \mathrm{Rd}}
$$

(Equação 2.4)

Em que:

- $\quad \chi$ é o fator de redução obtido em função do índice de esbeltez reduzido $\lambda_{0, \mathrm{~m}}$ que é determinado pela equação 2.5;

$$
\lambda_{0, m}=\sqrt{\frac{N_{p l, R}}{N_{e}}}
$$

- $\quad N_{p l, R d}$ é calculada pela equação 2.6: 
$N_{p l, R}=f_{y} A_{a}+\alpha f_{c k} A_{c}+f_{y s} A_{s}$

(Equação 2.6)

- Ne é a força axial de flambagem elástica dada por:

$$
N_{e}=\frac{\pi^{2}(E I)_{e}}{(K L)^{2}}
$$

- Em que $(\mathrm{KL})$ é o comprimento de flambagem determinado de acordo com a Norma e (El)e é a rigidez à flexão da seção transversal mista e é determinada pela equação 2.8 .

$$
(E I)_{e}=E_{a} l_{a}+0,6 E_{c, \text { red }} l_{c}+E_{s} l_{s}
$$

(Equação 2.8)

Sendo:

- la o momento de inércia da seção transversal do perfil de aço;

- Aa a área da seção transversal do perfil de aço;

- Is o momento de inércia da seção transversal da armadura de concreto;

- As a área da seção transversal da armadura de concreto;

- Ic o momento de inércia da seção transversal do concreto não fissurado;

- $\quad A_{c}$ a área da seção transversal do concreto não fissurado;

- Ea o módulo de elasticidade do aço estrutural;

- $E_{s}$ o módulo de elasticidade do aço da armadura;

- Ecred O módulo de elasticidade reduzido do concreto, calculado pela equação 2.9 . 


$$
E_{c, \text { red }}=\frac{E_{c}}{1+\varphi\left(\frac{N_{G, S d}}{N_{S d}}\right)}
$$

Onde:

- $E_{c}$ é o módulo de elasticidade do concreto;

- $\varphi$ é o coeficiente de fluência do concreto obtido pela ABNT NBR 6118. Simplificadamente admite-se que esse coeficiente seja tomado igual a 2,5 nas seções total ou parcialmente revestidas com concreto e igual a zero nas seções tubulares preenchidas com concreto e que a relação $\frac{N_{G, S d}}{N_{S d}}$ seja tomada igual a 0,6;

- Nsa é a força axial solicitante de cálculo;

- NG,Sa é a parcela da força axial solicitante de cálculo devida à ação permanente e à ação decorrente do uso de atuação quase permanente.

Dessa maneira $\chi$ é determinado pelas relações:

$$
\begin{aligned}
& \text { Se } \lambda_{0, m} \leq 1,5 \quad \therefore \quad \chi=0,658^{\lambda_{0, m}^{2}} \\
& \lambda_{0, m}>1,5 \quad \therefore \quad \chi=\frac{0,877}{\lambda_{0, m}^{2}}
\end{aligned}
$$

- $\quad N_{p l, R d}$ é a força axial resistente de cálculo à plastificação total é dada pela soma das forças axiais resistentes de cálculo de seus componentes: perfil de aço, concreto e armadura longitudinal, conforme apresentado na equação 2.10. 


$$
\mathrm{N}_{\mathrm{pl}, \mathrm{Rd}}=\mathrm{N}_{\mathrm{pl}, \mathrm{a}, \mathrm{Rd}}+\mathrm{N}_{\mathrm{pl}, \mathrm{c}, \mathrm{Rd}}+\mathrm{N}_{\mathrm{pl}, \mathrm{s}, \mathrm{Rd}}
$$

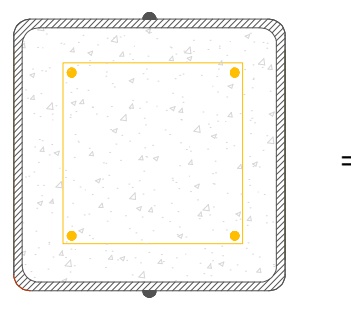

$\mathrm{N}_{\mathrm{pl}, \mathrm{Rd}}$

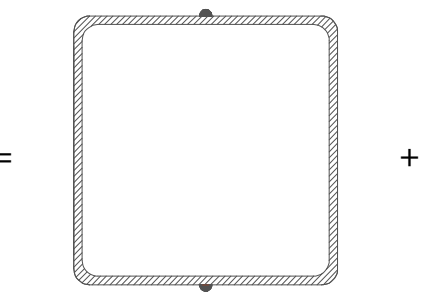

(Equação 2.10)

$N_{p l, a, R d}=f_{y d} A_{a} \quad N_{p l, c, R d}=f_{c d l} A_{c}$

$\mathrm{N}_{\mathrm{pl}, \mathrm{s}, \mathrm{Rd}}=\mathrm{f}_{\mathrm{sd}} \mathrm{A}_{\mathrm{s}}$

Em que:

$\mathrm{A}_{a}$ é a área da seção transversal do perfil de aço;

$\mathrm{A}_{\mathrm{s}}$ é a área da seção transversal da armadura longitudinal;

$\mathrm{A}_{c}$ é a área da seção transversal do concreto;

$\mathrm{f}_{\mathrm{cdl}}$ é igual ao produto $\alpha \mathrm{f}_{\mathrm{cd}}$

$\alpha$ é um coeficiente igual a 0,95 para seções tubulares preenchidas com concreto e 0,85 para as demais seções;

\subsection{Ligação Viga-Pilar}

Em um projeto estrutural constituído por elementos de aço, além do dimensionamento das vigas e pilares, o cálculo das ligações e seus diversos componentes é de extrema importância, uma vez que a resposta do sistema estrutural às ações depende das propriedades estruturais das mesmas. 
O termo "ligações" empregado aqui se refere à união viga-pilar, e são necessárias para transferir os esforços entre os elementos: pilar misto preenchido e viga de aço.

Os meios de ligação são os componentes que promovem a união entre as partes da estrutura para formar a ligação. São, por exemplo, os parafusos, as soldas e os pinos.

As ligações devem ser eficientes e capazes de transmitir, adequadamente, esses esforços do pilar de aço para o núcleo de concreto do pilar preenchido. As ligações entre os seus diversos componentes devem ser especificadas e calculadas de forma que seus esforços resistentes de cálculo sejam iguais ou superiores aos esforços solicitantes de cálculo.

A Figura 2.14 ilustra uma ligação entre um pilar misto preenchido e uma viga de aço.

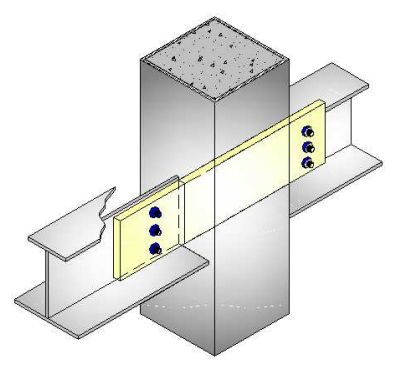

Figura 2.14. Exemplo de ligação entre viga de aço e pilar misto preenchido via chapa passante. De Nardin, 2007.

A ABNT NBR 8800:2008 traz a seguinte definição a respeito de ligações metálicas:

\begin{abstract}
"As ligações metálicas consistem em elementos de ligação, como enrijecedores, chapas de ligação, cantoneiras e consolos, e meios de ligação, como soldas, parafusos, barras redondas rosqueadas e pinos. Esses componentes devem ser dimensionados de forma que sua resistência de cálculo a um determinado estado limite último seja igual ou superior à solicitação de cálculo, determinada: (1) pela análise de estrutura sujeita às combinações de cálculo das ações; (2) como uma porcentagem especificada da resistência da barra ligada. Em algumas situações específicas, o dimensionamento pode também ter como base um estado limite de serviço".
\end{abstract}




\subsubsection{Geometria da ligação viga-pilar}

As ligações entre viga de aço e pilar tubular preenchido com concreto podem ser classificadas de acordo com a forma como os esforços são transferidos da viga para o pilar em 3 grupos: ligações externas, ligações internas e ligações mistas (De Nardin et a.l, 2007).

As ligações externas (Figuras 2.15 e 2.16 ) se caracterizam pela transferência direta de forças da viga para o pilar, podendo ser subdivididas em ligações enrijecidas e não enrijecidas.

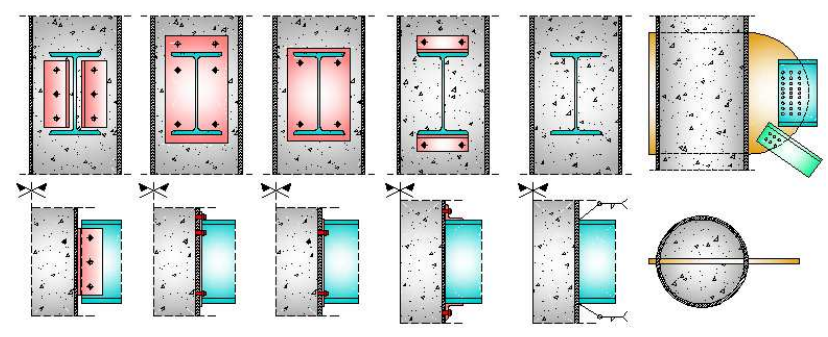

Figura 2.15. Ligação externa não enrijecida. De Nardin et a.l, 2007.

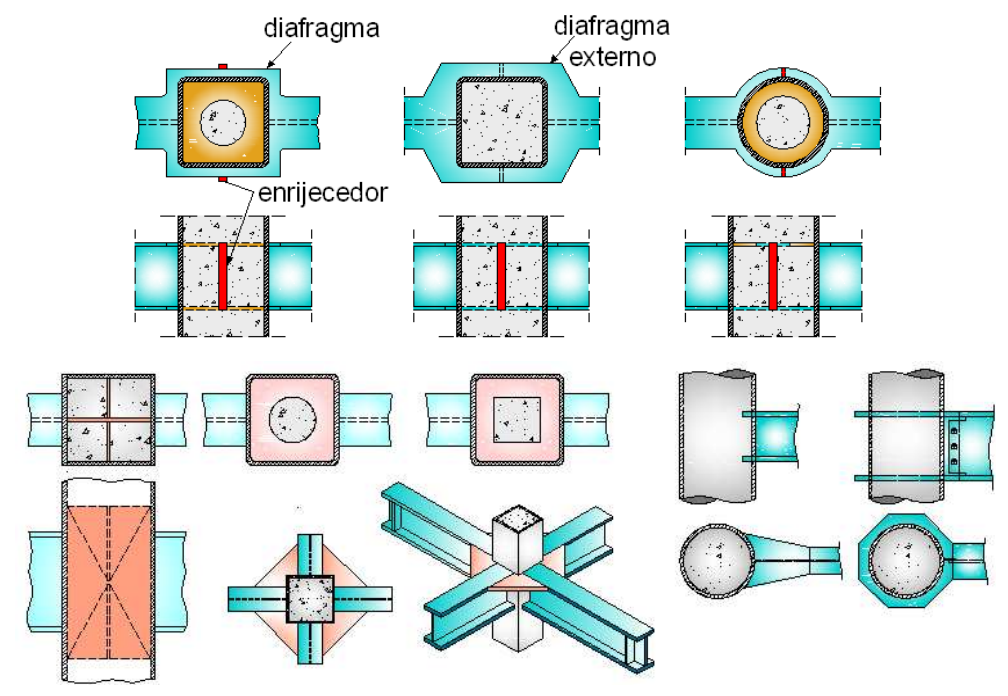

Figura 2.16. Ligação externa enrijecida. Fonte: De Nardin et al., 2007.

Nas ligações internas (Figura 2.17) parte do esforço da viga é transferido diretamente para o núcleo de concreto do pilar. A utilização de parafusos passantes e chapas de 
extremidade, conectores de cisalhamento e/ou barras de armadura soldadas às mesas e ancoradas no núcleo de concreto do pilar também é possível.

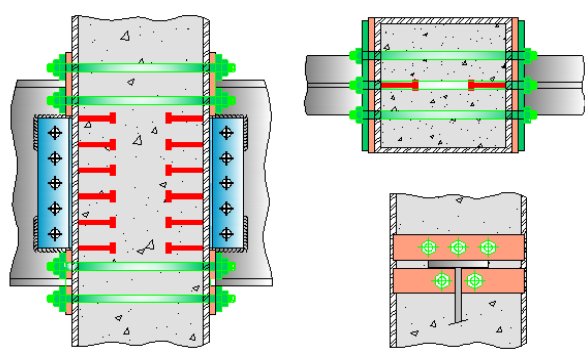

Figura 2.17. Ligação interna - conectores de cisalhamento e parafusos passantes. Fonte: Ricles et al., 2004 apud De Nardin et al., 2007.

As ligações mistas (Figura 2.18) são aquelas em que a laje de concreto participa da transmissão de momento fletor de uma viga mista para um pilar ou para outra viga mista no vão adjacente (ABNT NBR 8800:2008).

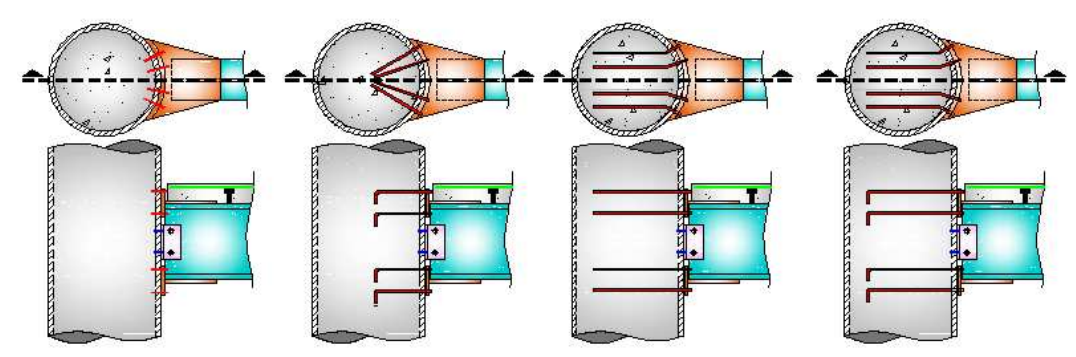

Figura 2.18. Ligação mista e pilares preenchidos circulares.

Fonte: Gardner et al., 2005 apud De Nardin et al., 2007.

\subsubsection{Estudo na área de ligação viga-pilar}

A transferência de esforços de cisalhamento da viga para o pilar misto preenchido pode ser analisada experimentalmente através de ensaios do tipo push-out. Prion (1994) realizou ensaios utilizando parafusos passantes como instrumento de transferência e dividiu a 
investigação experimental em dois grupos: um com aderência e outro sem aderência entre o parafuso e o núcleo de concreto. Os elementos sem aderência são assim denominados porque, durante o preenchimento do perfil tubular, os parafusos foram substituídos por tubos plásticos, removidos após o endurecimento do concreto. Nos vazios deixados pelos tubos foram colocados os parafusos longos. Já os elementos com aderência tiveram seus parafusos colocados antes do preenchimento do perfil tubular e ali permaneceram. A aplicação das forças verticais foi feita diretamente na chapa de extremidade, assim os parafusos eram submetidos apenas a esforços de cisalhamento (Figura 2.18).
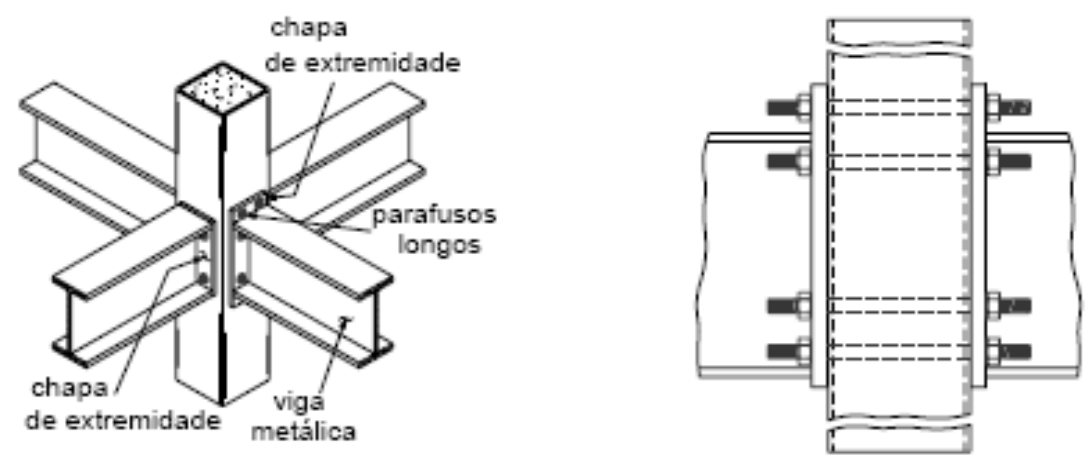

Figura 2.19. Esquema dos modelos estudado por Prion (1994) apud De Nardin (2003).

Durante o estudo de Prion (1994) foram observados três modos de ruptura da região de ligação: afastamento do parafuso junto à chapa; ruptura no concreto e separação do concreto e flexão do parafuso. A Figura 2.20 ilustra os três modos de ruptura citados por Prion (1994). 


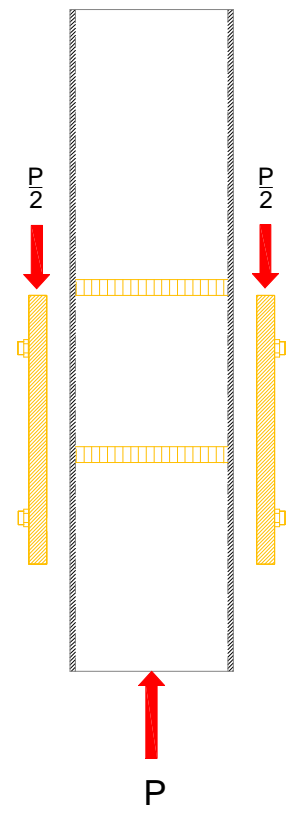

a) Ruptura no parafuso

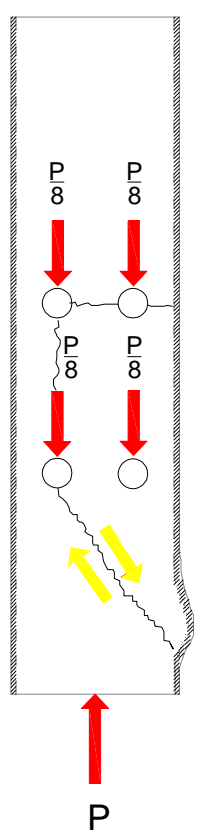

b) Ruptura no concreto

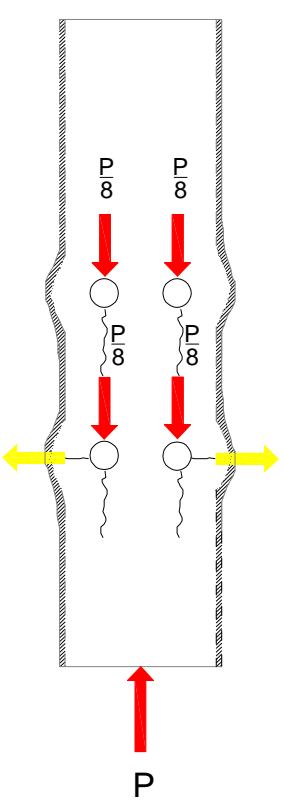

c) Ruptura do concreto e do parafuso

Figura 2.20. Modos de ruptura para ligações com parafusos passantes

Durante a transferência de esforços de cisalhamento, foi verificado o chamado "efeito de pino", que pode ser entendido como a introdução de esforços localizados sobre as barras de aço. A barra se comporta como um pino envolvido em um meio contínuo sujeito a uma força paralela à superfície.

Verifica-se que as altas tensões que ocorrem junto às bordas podem provocar a ruptura do concreto, e mais, que a capacidade de transmissão de forças diminui à medida que $\circ$ pino se aproxima da extremidade dos elementos. Podem ser tomadas algumas medidas de forma a aumentar a capacidade resistente, por exemplo, utilizando chapas de aço para confinar o concreto na superfície. 


\subsubsection{Dimensionamento de Ligação com Barras Redondas Rosqueadas Segundo a ABNT NBR 8800:2008}

A força de cisalhamento resistente de cálculo de um parafuso ou barra redonda rosqueada, de acordo com a referida norma, é expressa por plano de corte e dada por:

- Para parafusos de alta resistência, quando o plano de corte passa pela rosca e para parafusos comuns em qualquer situação:

$$
F_{v, R d}=\frac{0,4 A_{b} f_{u b}}{\gamma_{a 2}}
$$

Onde:

$A_{b}$ é a área bruta;

$\mathrm{f}_{\mathrm{ub}}$ é a resistência à ruptura do material do parafuso ou barra redonda rosqueada à tração;

$\gamma_{\mathrm{a} 2}$ é o coeficiente de ponderação da resistência para ruptura, igual a 1,35..

A norma faz uma ressalva quanto à força de protensão mínima de aperto no que diz respeito à instalação dos parafusos com protensão inicial:

"Os parafusos de alta resistência com protensão inicial devem ser apertados de forma a se obter uma força mínima de protensão adequada a cada diâmetro e tipo de parafuso usado".

O valor da força de protensão é apresentado na Tabela 2.3, que depende da categoria do aço utilizado e do diâmetro do parafuso. 
Tabela 2.3. Força de protensão mínima em parafusos ASTM. Fonte: ABNT NBR 8800:2008

\begin{tabular}{|c|c|c|c|}
\hline \multicolumn{2}{|c|}{ Diâmetro $d_{b}$} & \multicolumn{2}{|c|}{$\mathrm{F}_{\mathrm{Tb}}(\mathrm{kN})$} \\
\hline pol & $\mathrm{mm}$ & ASTM A325 & ASTM A490 \\
\hline $1 / 2$ & & 53 & 66 \\
\hline \multirow[t]{2}{*}{$5 / 8$} & & 85 & 106 \\
\hline & 16 & 91 & 114 \\
\hline \multirow[t]{3}{*}{$3 / 4$} & & 125 & 156 \\
\hline & 20 & 142 & 179 \\
\hline & 22 & 176 & 221 \\
\hline \multirow[t]{2}{*}{$7 / 8$} & & 173 & 216 \\
\hline & 24 & 205 & 257 \\
\hline \multirow[t]{2}{*}{1} & & 227 & 283 \\
\hline & 27 & 267 & 334 \\
\hline \multirow[t]{2}{*}{$11 / 8$} & & 250 & 357 \\
\hline & 30 & 326 & 408 \\
\hline \multirow[t]{2}{*}{$11 / 4$} & & 317 & 453 \\
\hline & 36 & 475 & 595 \\
\hline $11 / 2$ & & 460 & 659 \\
\hline
\end{tabular}

Na análise experimental foi necessário aplicar uma força de protensão às barras rosqueadas, por isso a importância da tabela acima.

\subsection{Considerações Finais}

Este capítulo apresentou os pilares mistos preenchidos, abordando conceitos, tipologias, vantagens, interação entre o aço e o concreto, efeito de confinamento e estudos relacionados a esse tema e, por fim, um enfoque no dimensionamento dos pilares mistos de acordo com a ABNT NBR 8800:2008. Foram abordadas também as ligações vigapilar no que diz respeito aos detalhes de ligação, conceitos, alguns estudos na área de cisalhamento de esforços em ligações com barras rosqueadas e, finalizando, uma abordagem da ABNT NBR 8800 no que diz respeito ao dimensionamento de barras redondas rosqueadas, que é o grande ponto de estudo deste trabalho de mestrado. 
Verificou-se, durante a pesquisa bibliográfica, uma carência enorme de trabalhos que tratem do tema cisalhamento em ligações com barras redondas rosqueadas. Dessa forma acredita-se que esse trabalho trará contribuições para o estudo das ligações vigapilar. 


\section{Análise Experimental}

A análise experimental realizada para o estudo da transferência de forças de cisalhamento na ligação entre o pilar misto preenchido e a viga de aço foi desenvolvida no Laboratório de Estruturas do Departamento de Engenharia de Estruturas da Escola de Engenharia de São Carlos (EESC).

Foram estudados 3 modelos físicos que se diferenciam pela presença e pelo tipo de conector de cisalhamento situado dentro do pilar misto preenchido. Cabe ressaltar que antes dos ensaios definitivos foi realizada uma série piloto com o objetivo de conhecer todo o procedimento envolvido no decorrer do ensaio, desde a concretagem, instrumentação, montagem do modelo e comportamento do dispositivo de ensaio. Com os resultados obtidos, foi possível corrigir alguns problemas de execução e comprovar que o esquema de ensaio inicialmente proposto funcionava adequadamente.

Neste capítulo serão apresentados os modelos físicos estudados, destacando sua geometria, materiais utilizados para a confecção dos mesmos, ensaios de caracterização dos materiais componentes e resultados, processo de confecção dos modelos, instrumentação adotada e o ensaio propriamente dito.

Foram mantidas as propriedades geométricas e físicas dos materiais e dos modelos para estarem em conformidade com os trabalhos desenvolvidos por De Nardin (2003), Silva (2006) e Farias (2007), dos quais este trabalho é continuidade. 


\subsection{Descrição dos modelos físicos}

Os 3 modelos físicos são compostos por um pilar misto preenchido e duas ligações viga-pilar, que é constituída por barras rosqueadas e chapas de extremidade. Esses elementos ensaiados se diferenciam pela presença ou ausência e pelo tipo de conector empregado na interface aço-concreto do pilar preenchido. A posição e geometria das chapas, parafusos e conectores foram mantidas constantes em todos os elementos ensaiados. A nomenclatura empregada nos modelos físicos e a variável de estudo são apresentadas na Tabela 3.1.

Tabela 3.1. Nomenclatura e variável estudada experimentalmente

\begin{tabular}{cc}
\hline Modelo & Tipo de conector de cisalhamento \\
\hline SBC - W & - \\
SBC - SB & Stud Bolt \\
SBC - A & Cantoneira \\
\hline
\end{tabular}

SBC - W : Steel Beam Column Without Conection.

SBC - SB : Steel Beam Column with Stud Bolt.

SBC - A : Steel Beam Column with Angle.

O modelo piloto, assim como o modelo SBC-W, não apresentava conectores de cisalhamento. O objetivo de realizar o ensaio piloto foi avaliar a metodologia e instrumentação inicialmente proposta. A partir dos resultados obtidos, observou-se a necessidade de aumentar a espessura da chapa de ligação para fornecer maior 
estabilidade durante o ensaio, haja vista que as reações de apoio são aplicadas diretamente na mesma.

A geometria dos modelos estudados é apresentada na Figura 3.1.

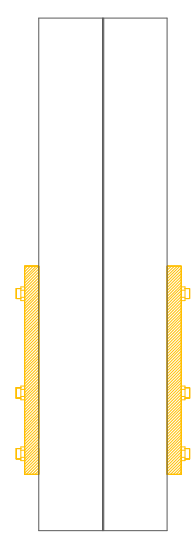

Vista frontal

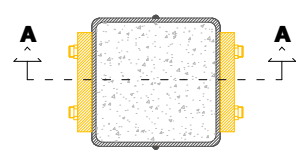

Seção Transversal

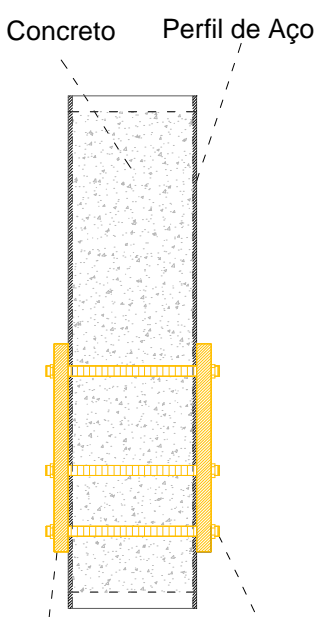

Chapa Metálica

Parafusos passantes
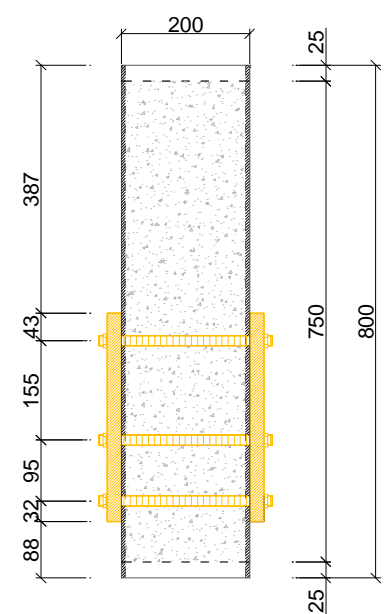

Figura 3.1. Geometria dos modelos de ligação ensaiados. (Medidas em mm).

O pilar misto preenchido apresenta comprimento de $800 \mathrm{~mm}$ e seção transversal quadrada de 200 × 200 mm. As dimensões no núcleo de concreto são 187,3 x 187,3 mm.

As Figuras 3.2, 3.3 e 3.4 apresentam os modelos estudados, suas geometrias e posição dos conectores de cisalhamento. 


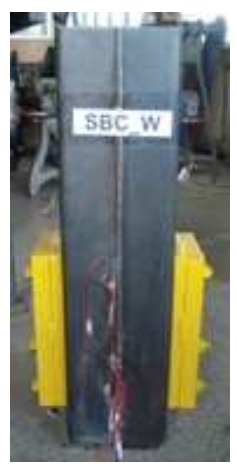

(a) Vista do pilar misto preenchido.

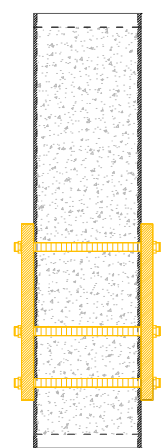

(b) Pilar misto preenchido em corte.
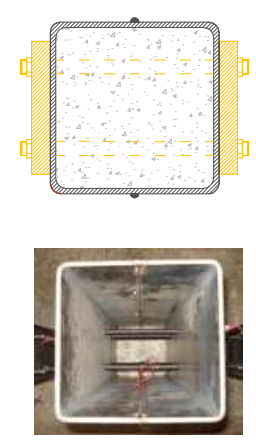

(c) Seção transversal.

Figura 3.2. Modelo SBC_W: sem conector de cisalhamento.

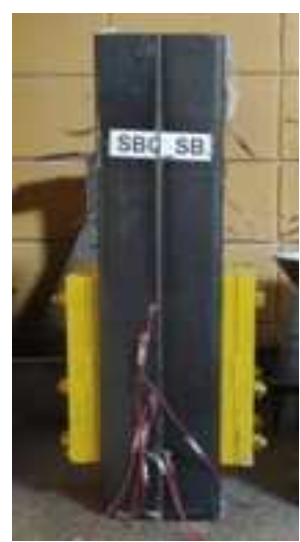

(a) Pilar em vista.

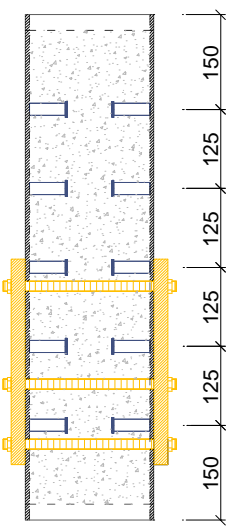

(b) Arranjo dos conectores no pilar.

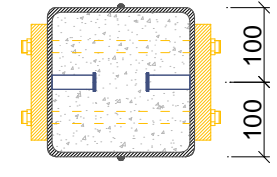

$|56 \nmid 88| 56 \mid$

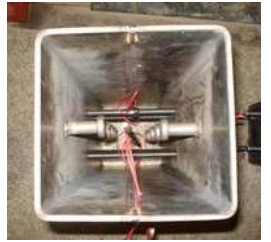

(c) Seção transversal.

Figura 3.3. Modelo SBC_SB: conector de cisalhamento tipo pino com cabeça.

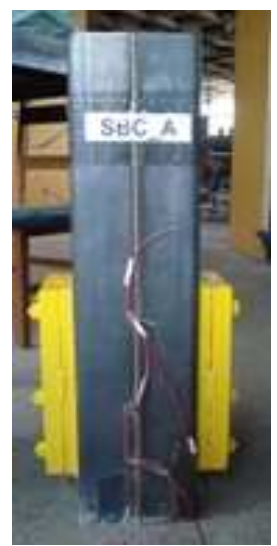

(a) Pilar em vista.

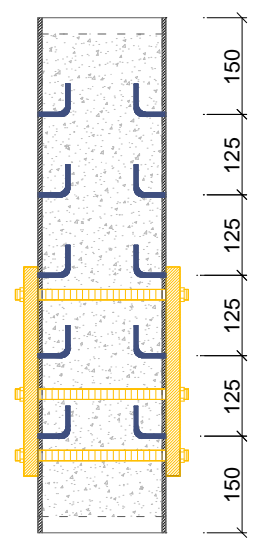

(b) Arranjo dos conectores no pilar.
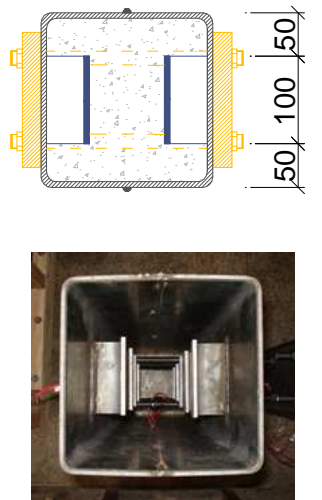

(c) Seção transversal.

Figura 3.4. Modelo SBC_A: conector de cisalhamento tipo cantoneira. 


\subsection{Instrumentação}

Com o objetivo de acompanhar a evolução das deformações no núcleo de concreto, no perfil de aço e nas barras rosqueadas, foram distribuídos extensômetros elétricos de resistência conforme ilustrado na Figura 3.5.

O arranjo dos extensômetros no pilar de aço, no núcleo de concreto e nas barras rosqueadas foi tal que, na análise dos resultados, fosse possível identificar a porcentagem de força transferida para o pilar de aço, para o núcleo de concreto e para as barras rosqueadas. Sendo assim, visando tal avaliação, foi adotada a mesma distribuição de extensômetros no núcleo de concreto e no pilar de aço.

Externamente ao perfil, foram posicionados transdutores de deslocamentos para medir o escorregamento relativo entre o núcleo de concreto e o perfil de aço, no topo e na base do pilar misto preenchido (Figura 3.5).
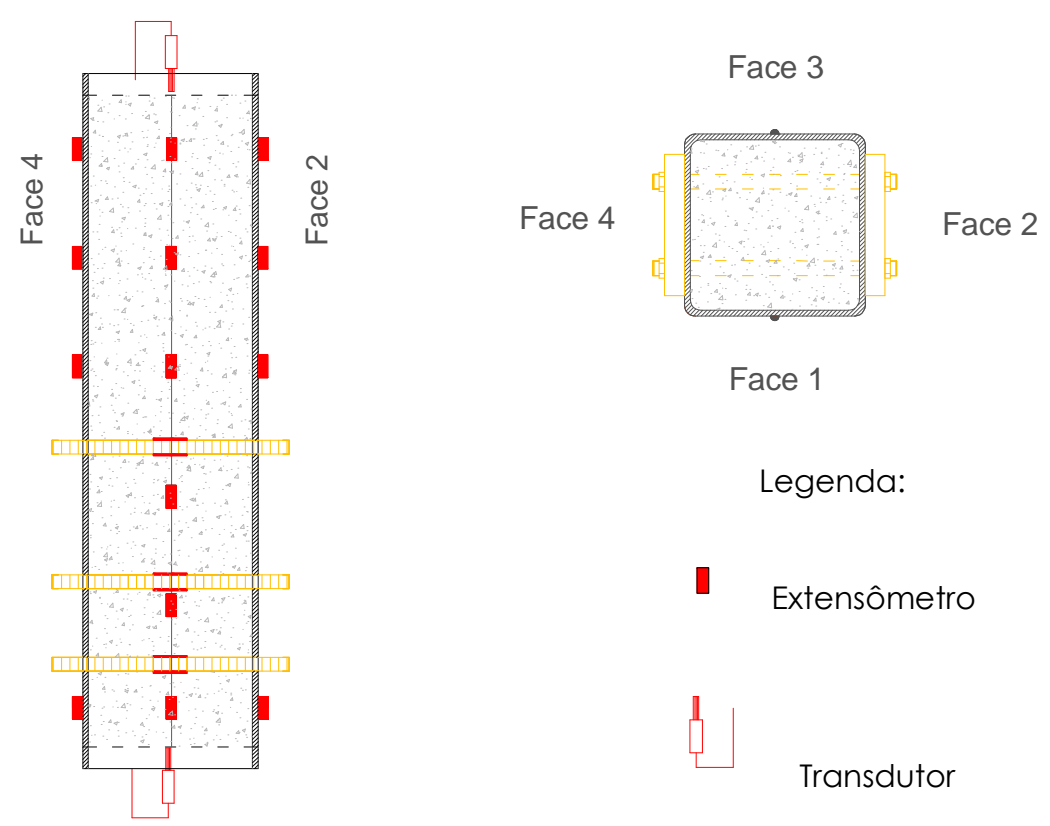

Figura 3.5. Instrumentação dos modelos 
A especificação dos extensômetros é apresentada na Tabela 3.2.

Tabela 3.2. Especificação dos extensômetros elétricos empregados.

\begin{tabular}{cc} 
Marca & KYOWA \\
Tipo & KFG-5-120-C1-11 \\
Comprimento & $10 \mathrm{~mm}$ \\
\hline
\end{tabular}

A especificação dos transdutores de deslocamento adotados é apresentada na Tabela 3.3.

Tabela 3.3. Especificação dos transdutores de deslocamentos

\begin{tabular}{ccc}
\hline & Transdutor superior & Transdutor inferior \\
\hline Marca & KYOWA & KYOWA \\
Tipo & HS 10 MG 7432 & DTH - A - 20 \\
Comprimento & $10 \mathrm{~mm}$ & $20 \mathrm{~mm}$ \\
\hline
\end{tabular}

A seguinte nomenclatura foi adotada para a identificação dos pontos de leitura dos deslocamentos e deformações:

- PERFIL DE AÇO: A letra S indica que o extensômetro está localizado no aço (Steel), seguido de um número que informa a linha de localização e, posteriormente, da indicação do lado em queo extensômetro se encontra: lado direito (Right) ou esquerdo (Left).

- CONCRETO: Para o concreto foi utilizada a letra C (Concrete), seguida de um número que informa a linha de localização.

- BARRAS ROSQUEADAS: Nas barras rosqueadas a nomenclatura inicia com a letra B (Bolt), seguidade um número que indica a posição da barra e, finalizando, as letras $U$ 
ou D, que significam Up ou Down, indicando a posição da barra rosqueada na região de ligação.

A Figura 3.6 apresenta a instrumentação adotada em cada componente.

$1 \quad$ Transd. 1 Transd. 2

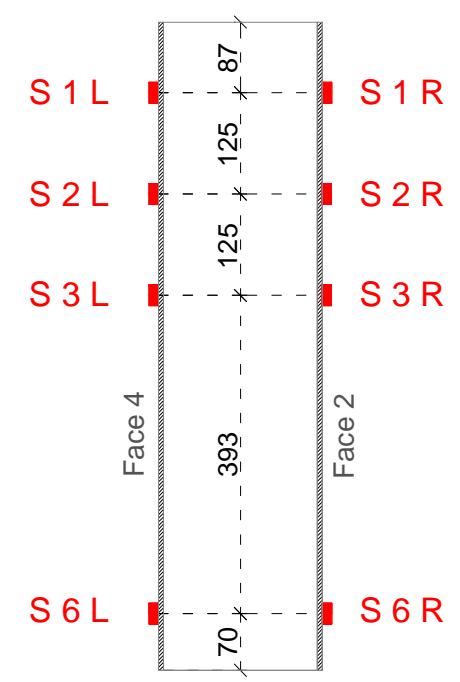

(a) Perfil metálico.

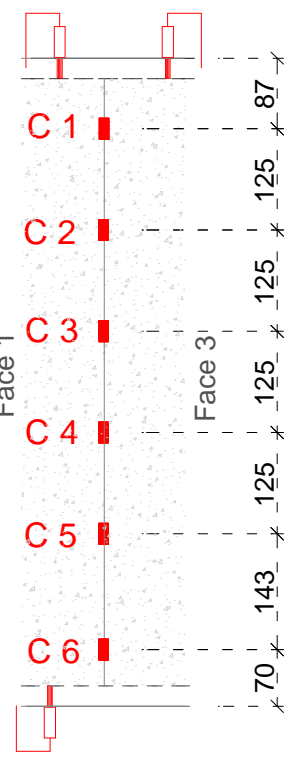

Transd. 3
B 1_U

B 1_D

B 2 U U

B 3_U B 2 - D

B 3_D

(b) Núcleo de concreto.

(c)Barras rosqueadas.

Figura 3.6. Distribuição da instrumentação e numeração dos pontos. (Medidas mm).

Ao longo da altura do perfil de aço foram posicionados 4 extensômetros em cada face, sendo dispostos entre os locais em que há presença de conectores de cisalhamento. Dessa forma, foi possível acompanhar e avaliar a transferência de forças entre concreto e aço ao longo do comprimento do pilar e também a contribuição dos conectores de cisalhamento para tal mecanismo. 


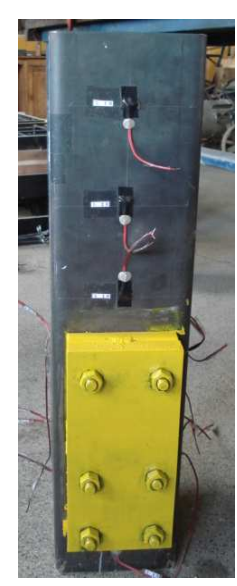

Figura 3.7. Instrumentação do perfil de aço.
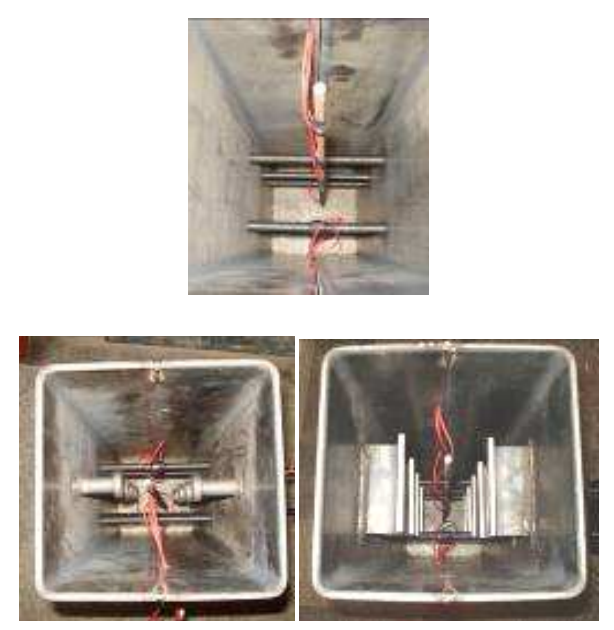

Figura 3.8. Instrumentação do núcleo de concreto.

No concreto, foram feitas medidas de deformações e de deslocamentos. Os transdutores foram posicionados nas superfícies superior e inferior do concreto, com o objetivo de medir o deslocamento relativo do núcleo de concreto em relação ao perfil de aço. Para a medida das deformações no núcleo de concreto, foi instrumentada uma barra lisa de aço de pequeno diâmetro, que foi imersa na massa de concreto durante a concretagem. Os pontos instrumentados na barra de aço correspondem aos pontos instrumentados no perfil de aço, exceto os pontos $C_{4}$ e $C_{5}$, que foram suprimidos do perfil devido à presença das chapas de ligação.
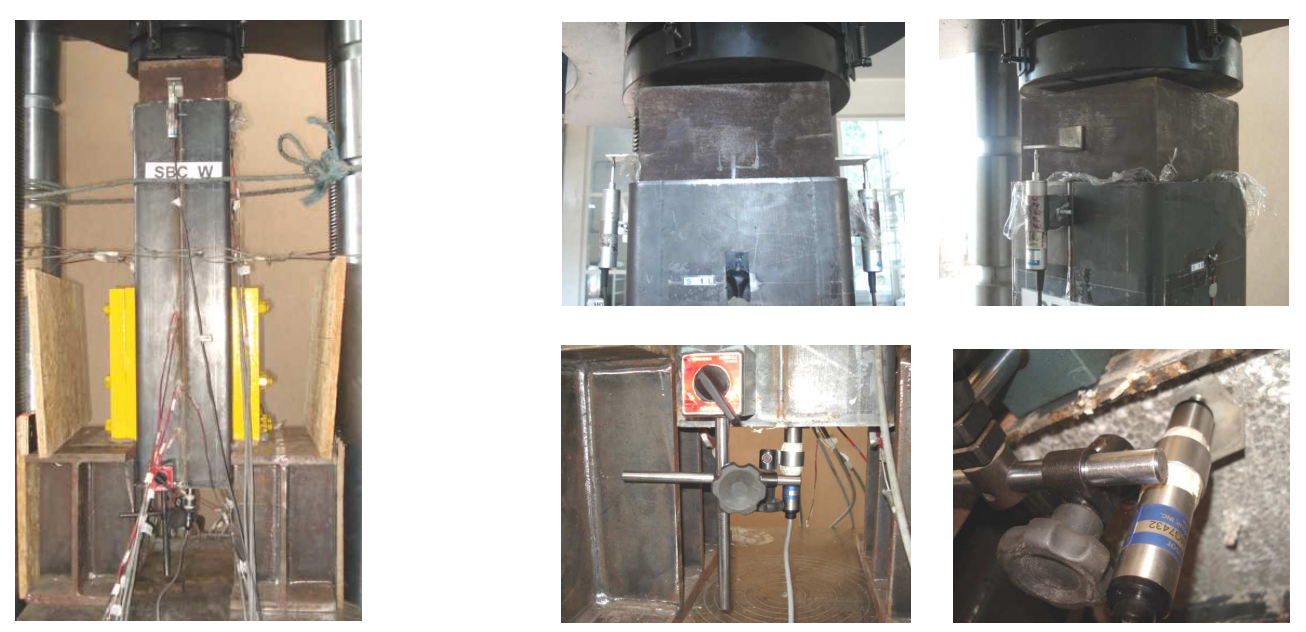

Figura 3.9. Transdutores de deslocamento nas regiões superior e inferior dos modelos. 
Os extensômetros colados nas barras rosqueadas foram isolados visando impedir danos provocados pelo concreto em estado fresco e pelo aquecimento devido à solda de composição do perfil tubular.

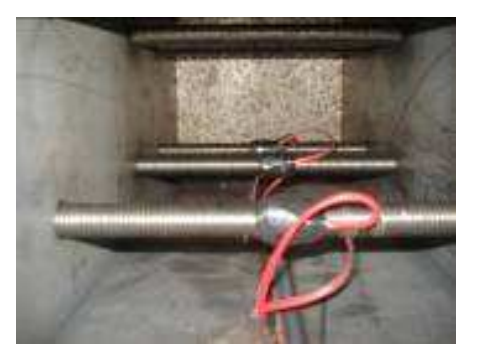

Figura 3.10. Instrumentação das barras rosqueadas.

\subsection{Materiais e Componentes}

Os materiais utilizados na confecção dos modelos, as propriedades físicas e geométricas são apresentados nos itens a seguir.

\subsubsection{Perfil de aço}

Os perfis de aço de seção quadrada com $200 \mathrm{~mm}$ de lado foram obtidos a partir da soldagem de dois perfis formados a frio, de seção "U", de dimensões 200 x 100 x 6,3 mm e comprimento de $800 \mathrm{~mm}$. O aço utilizado nos perfis foi do tipo SAE 1020. Apesar de não ser um aço estrutural (CIVIL 300 ou CIVIL 350 ou ASTM A 36) e sim um aço do tipo mecânico, segui-se os demais trabalhos desenvolvidos nessa linha de pesquisa.

As propriedades mecânicas resistência ao escoamento ( $\left.f_{y}\right)$ e resistência à ruptura ( $\left.f_{u}\right)$ foram obtidas por meio de ensaios de caracterização, em que foram extraídos 4 corpos de prova da alma do perfil tubular, inclusive da região da solda. Esses corpos de prova foram 
ensaiados à tração axial, de acordo com a ASTM E-8 no Laboratório do Departamento de Engenharia de Materiais da EESC.

A Figura 3.11 ilustra o perfil de aço utilizado para extração dos corpos de prova e a Figura 3.12 as dimensões dos corpos de prova.

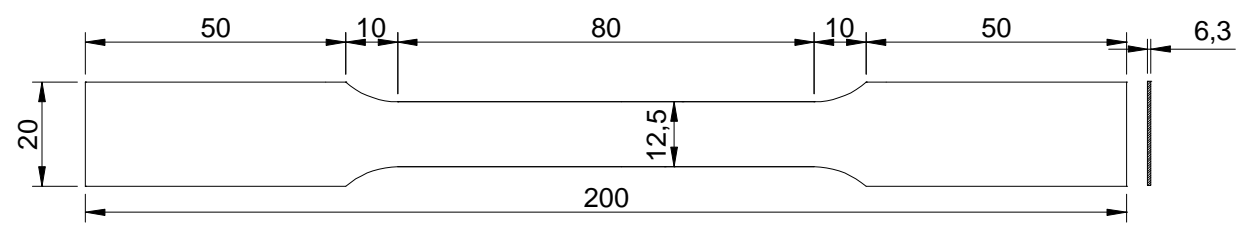

Figura 3.11. Dimensões do corpo de provã (Medidas em mm).

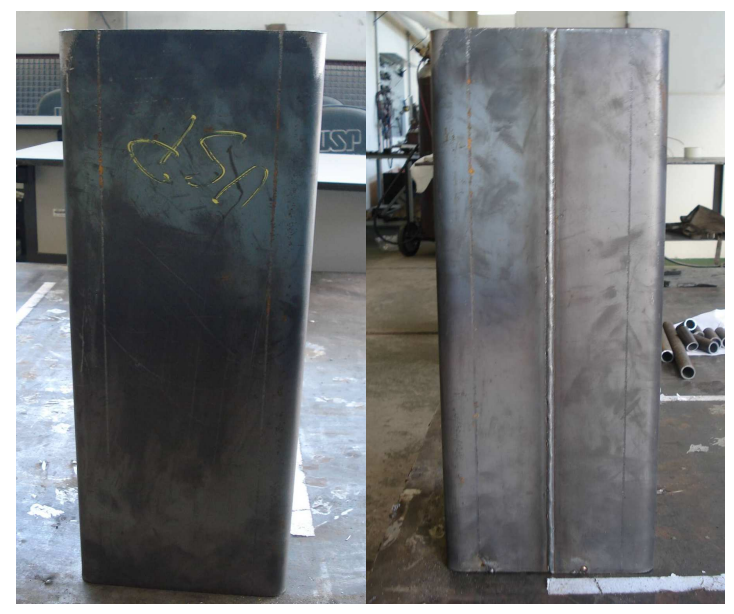

(a) Vista do pilar metálico. Região sem e com solda. (b) Seção transversal do perfil de aço para extração dos corpos de prova.

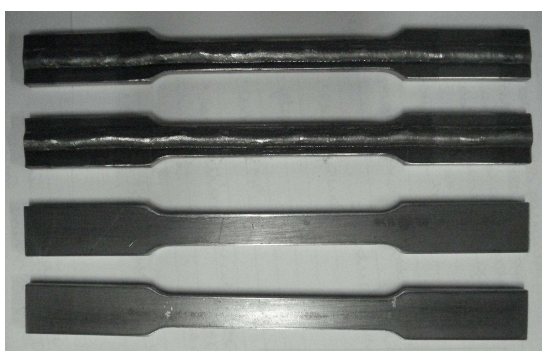

(c) Corpos de prova.

Figura 3.12. Amostras para caracterização do aço do perfil.

O ensaio de caracterização mecânica do aço foi realizado na máquina universal de ensaios EMIC DL 5000/10000 com célula de carga de 100 kN, com auxílio do software do 
sistema de aquisição de dados TESC versão 1.13. Para as leituras dos deslocamentos foi utilizado o clip gage da marca EMIC modelo EEPA 6001, com base de leitura de $50 \mathrm{~mm}$. A área da seção transversal do corpo de prova com solda foi determinada por meio de um analisador de imagens IMAGE PRO PLUS versão 4.5.0.29, de maneira a obter a área mais exata possível, devido às imperfeições ocasionadas pela solda.
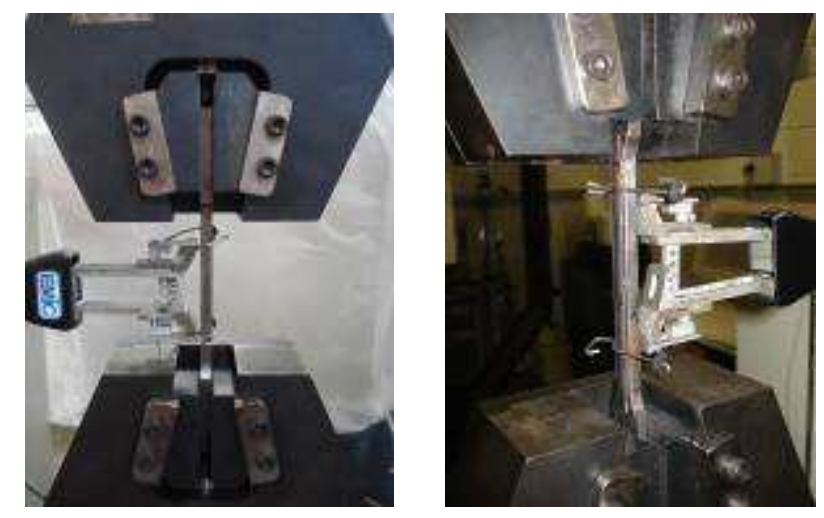

(a) Corpo de prova sendo ensaiado.

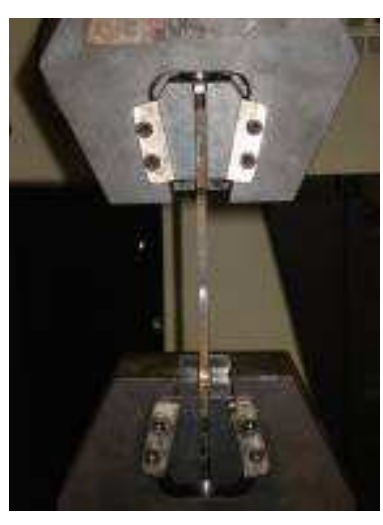

(b) Escoamento da seção transversal.
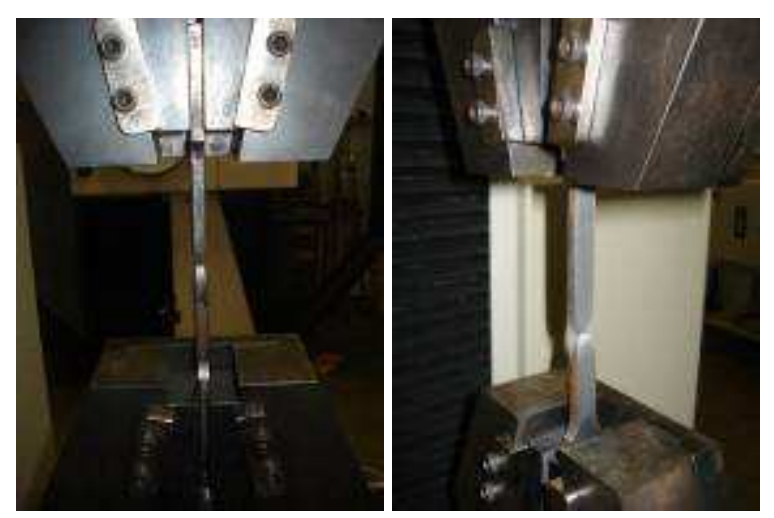

(c) Ruptura da seção transversal.

Figura 3.13. Ensaio de caracterização do perfil de aço.

As propriedades mecânicas obtidas no ensaio de caracterização do aço são apresentadas na Tabela 3.4 e as curvas tensão vs. deformação são mostradas na Figura 3.14 . 
Tabela 3.4. Propriedades mecânicas do aço do perfil.

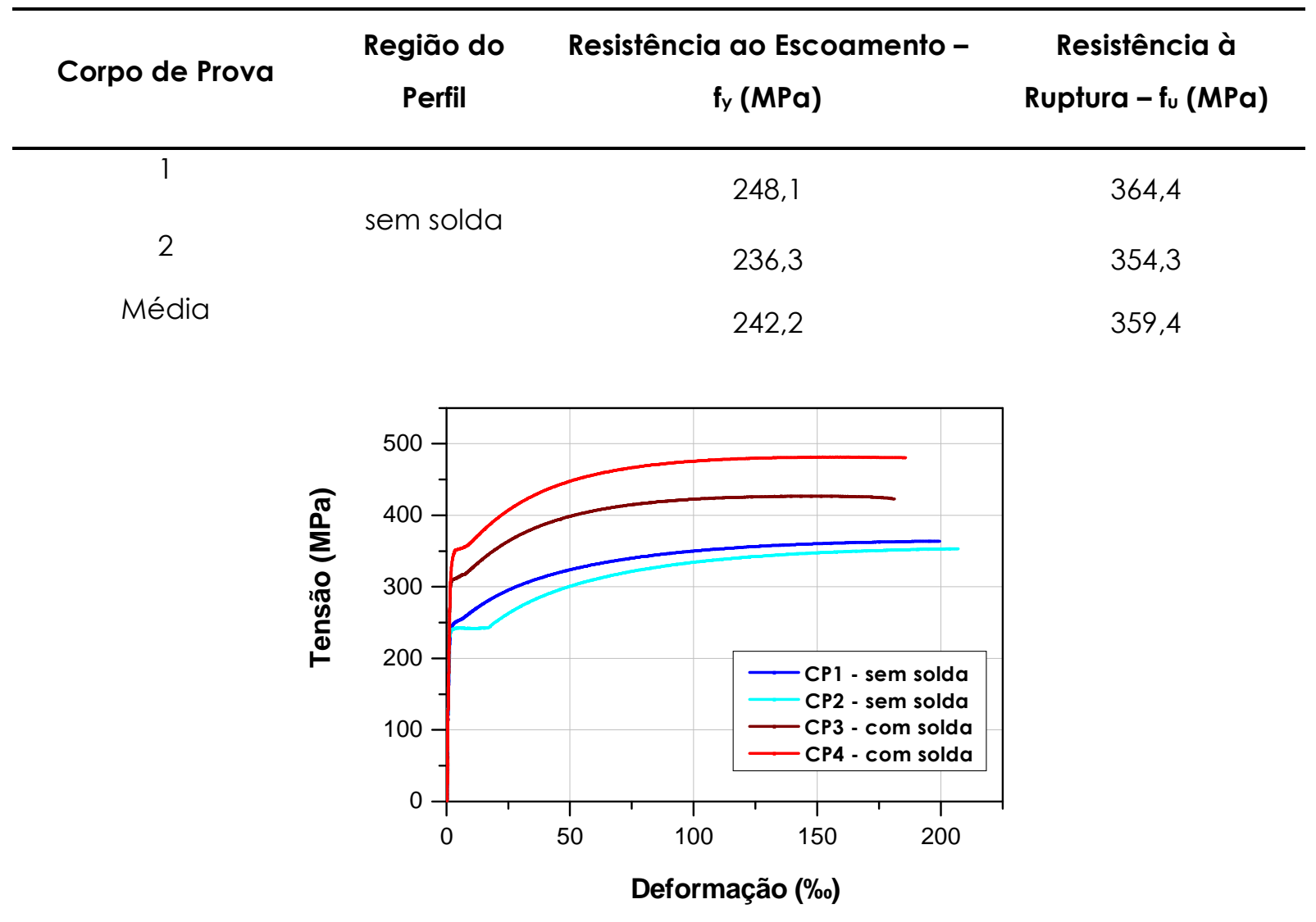

Figura 3.14. Curvas do ensaio de caracterização do aço do perfiĩ.

\subsubsection{Concreto}

O concreto para preenchimento do perfil foi dosado visando uma resistência à compressão de 50 MPa quando dos ensaios dos modelos.

A proporção em massa utilizada para tal dosagem foi 1:1,5:2,7 (cimento, areia, brita, água), com relação água/cimento de 0,55 e $5 \%$ de sílica ativa, em relação à massa de cimento. O consumo de materiais por metro cúbico é apresentado na Tabela 3.5. 
Tabela 3.5. Consumo de materiais - concreto

\begin{tabular}{cc}
\hline Materiais & Consumo $\left(\mathbf{k g} / \mathbf{m}^{\mathbf{3}}\right)$ \\
\hline Cimento & 424,4 \\
Agregado miúdo & 636,7 \\
Agregado graúdo & 1146 \\
Sílica & 21,2 \\
Água & 233,4 \\
\hline
\end{tabular}

As características dos materiais são as seguintes:

- Cimento: CP-V ARI, cimento Portland com alta resistência inicial da marca Holcim, fabricado pela Ciminas.

- Agregado miúdo: areia quartzosa.

- Agregado graúdo: agregado de origem basáltica, da pedreira Morado do Sol, Araraquara -SP.

- Sílica: Silmix fabricada pela Camargo Correia.

As propriedades mecânicas (resistência à compressão, resistência à tração, módulo de elasticidade e energia de fraturamento) e consistência do concreto foram obtidas por meio de ensaios de caracterização no Laboratório de Estruturas da EESC.

No total, foram moldados 6 corpos de prova cilíndricos de $10 \times 20 \mathrm{~cm}$, sendo 3 para a determinação da resistência à tração diametral e 3 para a determinação da resistência à compressão e módulo de elasticidade (Figura 3.15). Além destes, 5 corpos de prova retangulares foram usados na determinação da energia de fraturamento. 

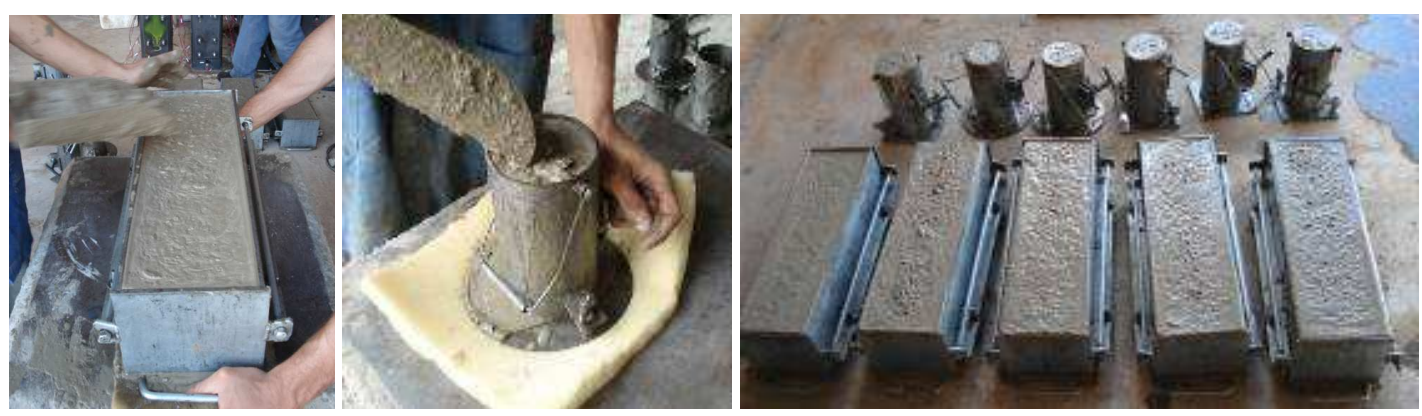

Figura 3.15. Moldagem dos corpos de prova cilíndricos e retangulares.

A consistência do concreto foi determinada por meio do ensaio de abatimento do tronco de cone conforme a ABNT NBR 7223:1992 (Figura 3.16).
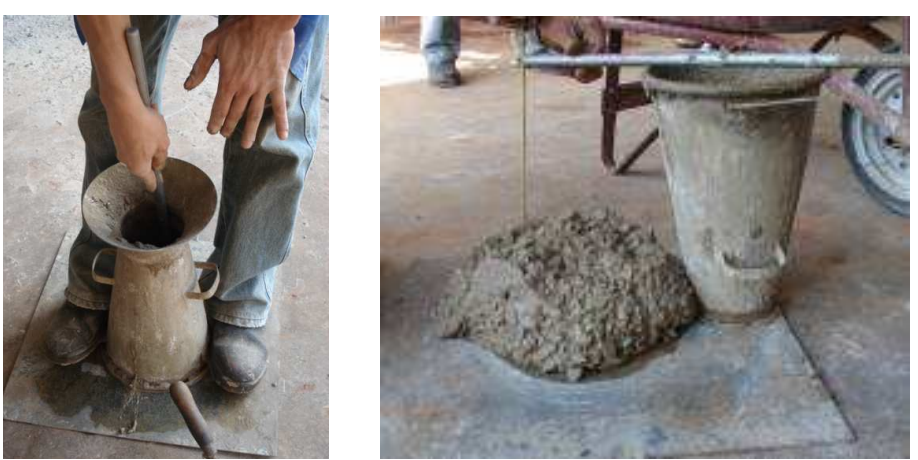

Figura 3.16. Ensaio de abatimento do tronco de cone.
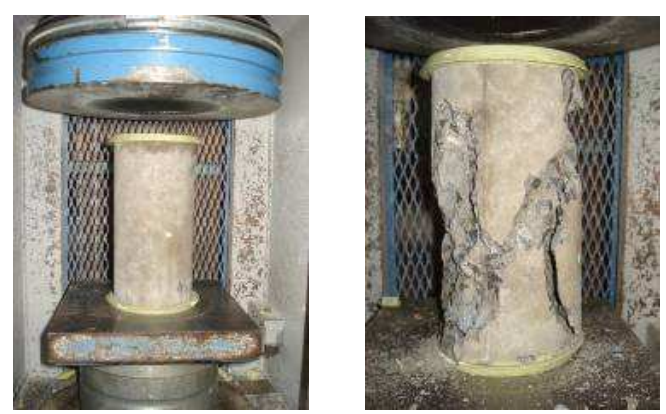

Figura 3.17. Ensaio de resistência à compressão axial.
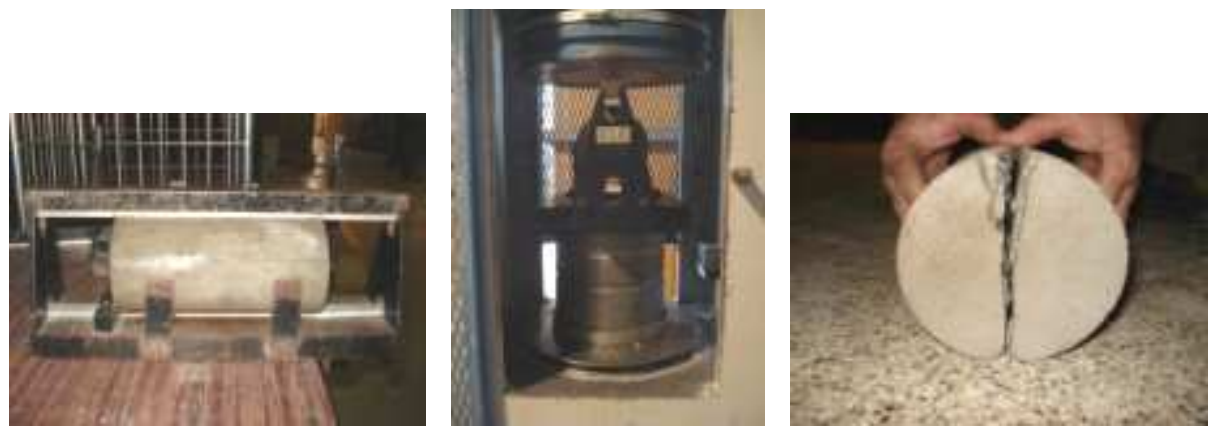

Figura 3.18. Ensaio de resistência à tração por compressão diametral. 

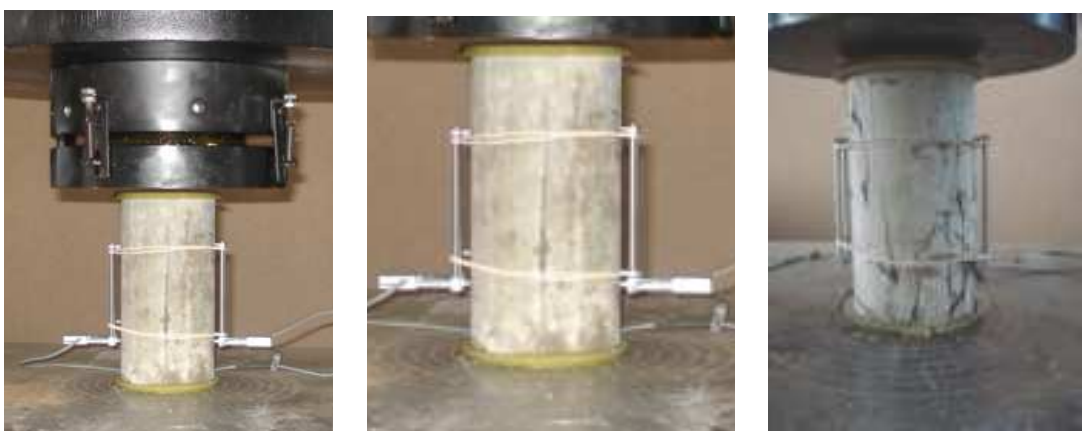

Figura 3.19. Ensaio de compressão para determinação do módulo de elasticidade.

Para a determinação da energia de fraturamento foram moldadas vigas prismáticas com as dimensões de $15 \times 15 \times 50 \mathrm{~cm}$ (Figura 3.20). A determinação experimental da energia de fraturamento $\left(G_{f}\right)$ foi realizada de acordo com os procedimentos da RILEM (Comitê técnico $n^{\circ} 50,1990$ ), ensaio este fundamentado no modelo da fissura fictícia de HILLERBORG (1976).

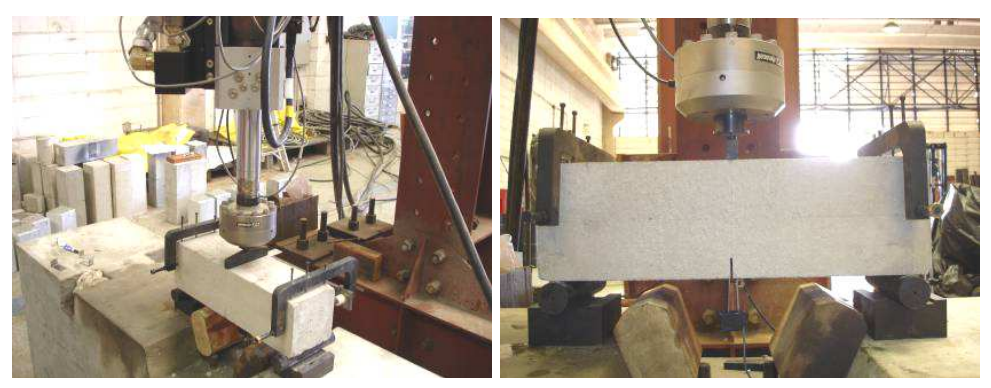

Figura 3.20. Ensaio de energia de fraturamento

A Tabela 3.6 apresenta os resultados dos ensaios de caracterização do concreto, destacando que os resultados de resistência à compressão e módulo de elasticidade correspondentes aos 21 dias. Esses valores serão utilizados na análise numérica como parâmetro de caracterização do concreto. 
Tabela 3.6: Propriedades mecânicas do concreto.

$\begin{array}{cc}\text { Consistência do concreto - slump } & 200 \mathrm{~mm} \\ \text { Resistência média à compressão } & 54,92 \mathrm{MPa} \\ \text { Resistência média à tração } & 3,68 \mathrm{MPa} \\ \text { Módulo de elasticidade } & 35,10 \mathrm{GPa} \\ \text { Energia de fraturamento } & 96,23 \mathrm{~N} / \mathrm{m}\end{array}$

\subsubsection{Conector de cisalhamento tipo pino com cabeça}

Os conectores de cisalhamento tipo pino com cabeça (stud bolt) empregados nos modelos físicos apresentam 19,1 mm de diâmetro e $56 \mathrm{~mm}$ de comprimento. A Figura 3.21 ilustra o conector utilizado e as dimensões.
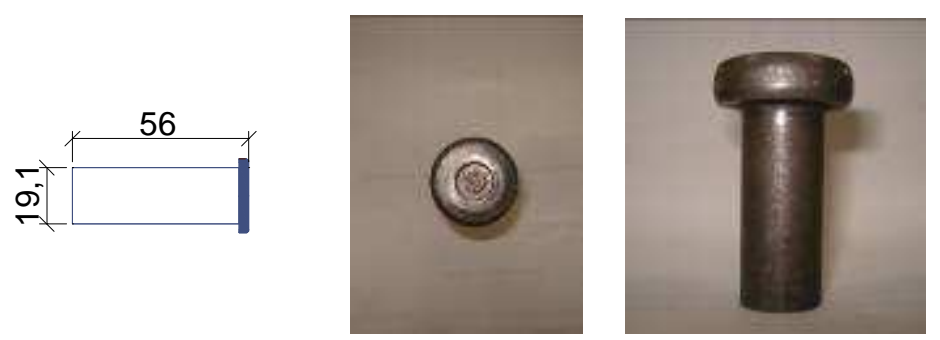

Figura 3.21. Conector de cisalhamento tipo pino com cabeça. (Medidas em mm).

\subsubsection{Conector de cisalhamento tipo cantoneira}

Para desempenhar o papel de conector de cisalhamento também foram utilizados perfis formados a frio tipo cantoneira $L 50 \times 6,35 \mathrm{~mm}$, confeccionados em aço tipo SAE 1020 e com comprimento de $100 \mathrm{~mm}$. A Figura 3.22 ilustra a geometria da cantoneira utilizada como conector de cisalhamento. 

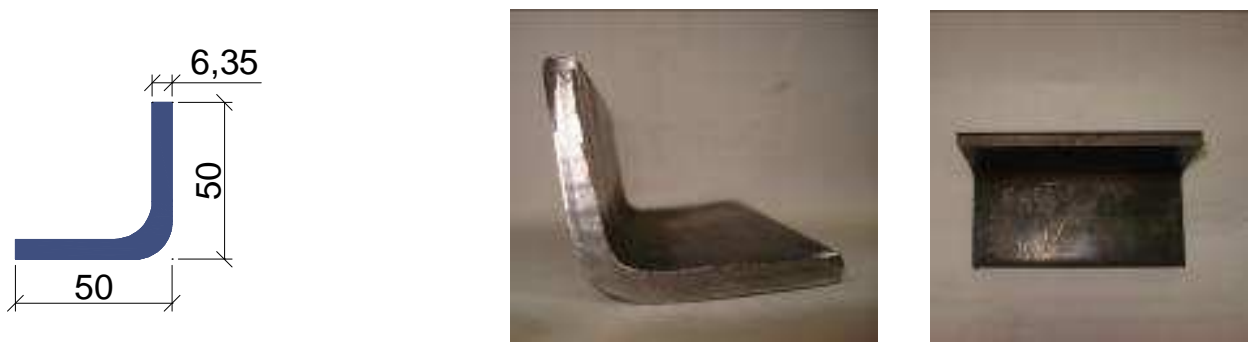

Figura 3.22. Conector de cisalhamento tipo cantoneira. (Medidas em $\mathrm{mm}$ ).

\subsubsection{Barras rosqueadas}

Nos modelos de ligação investigados, as barras rosqueadas funcionam como parafusos passantes. Apresentam diâmetro de 5/8", e foram fabricadas em aço de alta resistência A 193 B7, ASTM A 325, nos comprimentos de 350 mm e 800 mm (este último para o ensaio de caracterização das barras rosqueadas).

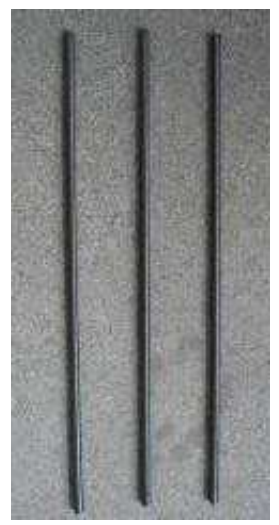

Figura 3.23. Barras rosqueadas.

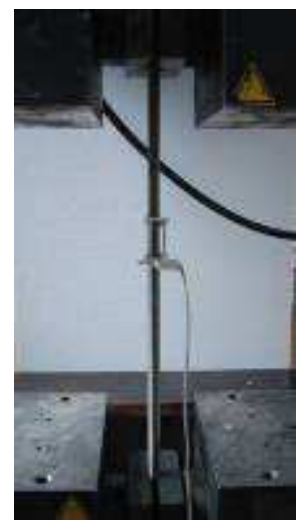

(a) Ensaio.

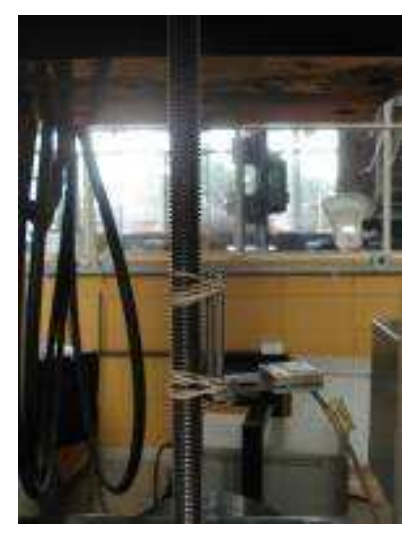

(b) Clip Gage.

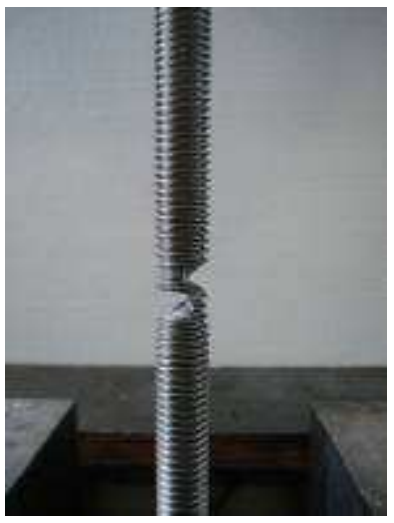

(c) Modo de ruptura.

Figura 3.24. Ensaio de caracterização das barras rosqueadas.

A caracterização do aço das barras rosqueadas foi realizada por meio de ensaio de tração na Máquina servo-controlada INSTRON 8500, utilizando o sistema de aquisição de dados SYSTEM 5000. A velocidade de ensaio foi de $0,05 \mathrm{~mm} / \mathrm{s}$ até a medida de deslocamento atingir o valor de 1,2 $\mathrm{mm}$. Uma vez atingido esse valor de deslocamento, 0 
instrumento de medida dos deslocamentos, clip gage, foi retirado para evitar danificar o equipamento. O clip-gage foi retirado e a partir disso, a velocidade foi aumentada para 0,5 $\mathrm{mm} / \mathrm{s}$. Nesse ensaio de tração foram determinados os valores de resistência ao escoamento $\left(f_{y}\right)$ e resistência à ruptura $\left(f_{u}\right)$, utilizando 3 corpos de prova de $800 \mathrm{~mm}$ de comprimento. A figura 3.24 ilustra o ensaio realizado.

Os valores experimentais de resistência ao escoamento e a resistência à ruptura das barras rosqueadas são apresentados na Tabela 3.7.

Tabela 3.7. Propriedades mecânicas do aço.

\begin{tabular}{ccc}
\hline Corpo de Prova & $\begin{array}{c}\text { Resistência ao Escoamento } \\
(\mathbf{M P a})\end{array}$ & $\begin{array}{c}\text { Resistência à Ruptura } \\
(\mathbf{M P a})\end{array}$ \\
\hline 1 & 770,57 & 787,29 \\
2 & 733,97 & 777,67 \\
3 & 727,23 & 791,33 \\
\hline Média & 743,92 & 785,43 \\
\hline
\end{tabular}

Os valores da resistência ao escoamento foram determinados por meio do método off-set, uma vez que os gráficos tensão $X$ deformação não apresentam patamar de escoamento definido. 


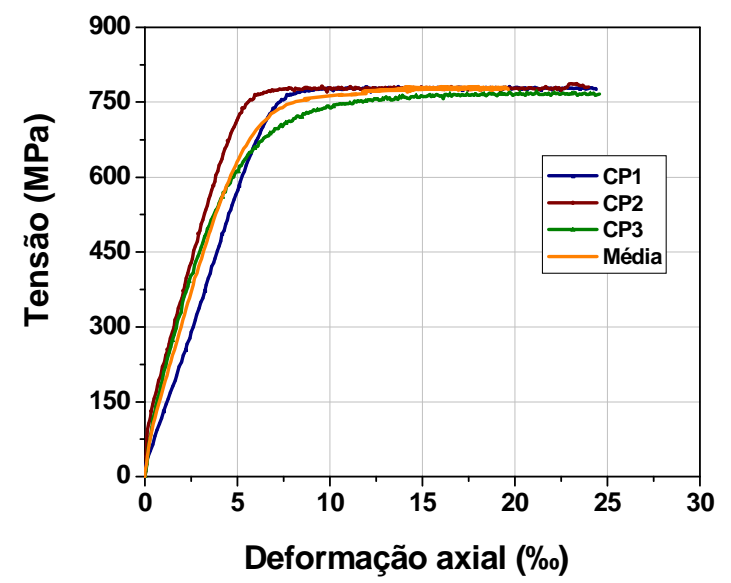

Figura 3.25. Tensão X Deformação axial - Ensaio de caracterização das barras rosqueadas.

\subsubsection{Porcas sextavadas}

As porcas sextavadas pesadas são de 5/8", fabricadas em aço SAE 1045, tratadas para serem utilizadas nas barras rosqueadas, fazendo a ligação da chapa de aço ao pilar misto preenchido.

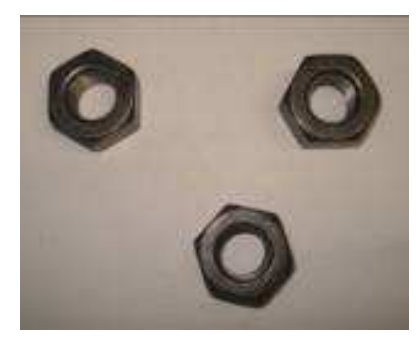

Figura 3.26. Porcas sextavadas

\subsubsection{Chapa de aço}

A chapa de aço que representa a ligação com chapa de extremidade apresenta dimensões de $325 \times 155$ mm. Embora na ligação seja empregada apenas uma chapa em cada extremidade de viga, na realização dos ensaios foram necessárias duas chapas 
sobrepostas para garantir maior estabilidade durante o ensaio. Sendo assim, foram utilizadas uma chapa de espessura de $22,1 \mathrm{~mm}$ e outra de espessura de $32,0 \mathrm{~mm}$, ambas fabricadas em aço ASTM A 36, com furos de 18 mm de diâmetro (figura 3.27).
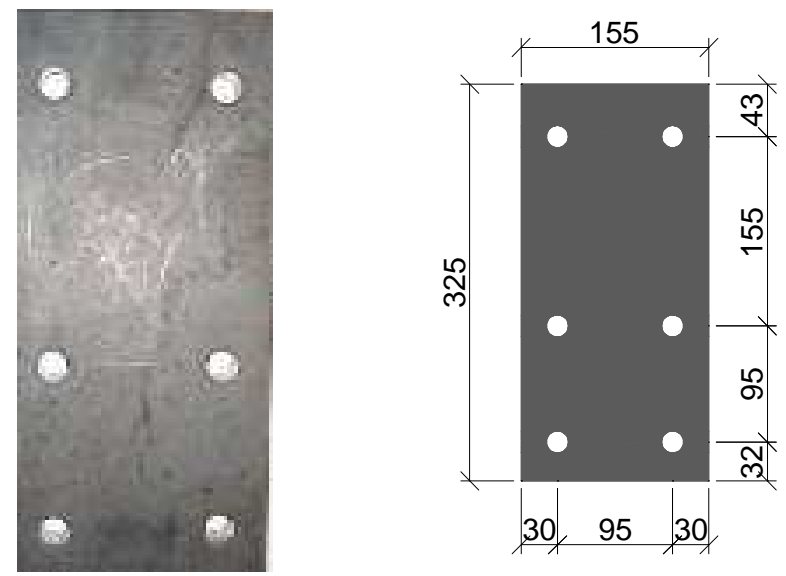

Figura 3.27. Chapa de aço. (Medidas em mm).

\subsection{Confecção dos Modelos}

Os 3 modelos estudados foram confeccionados na Escola de Engenharia de São Carlos, sendo algumas etapas realizadas na Oficina Mecânica do Departamento de Engenharia Mecânica e outras no Laboratório de Estruturas do Departamento de Estruturas.

As etapas de produção dos modelos foram:

- Confecção dos furos no perfil de aço;

- Soldagem dos conectores de cisalhamento no interior dos perfis U e soldagem dos perfis para composição da seção quadrada;

- Instrumentação das barras rosqueadas;

- Colocação das barras rosqueadas no interior do perfil de aço; 
- Confecção dos pilares de aço;

- Colocação das barras rosqueadas restantes e chapas metálicas;

- Instrumentação do perfil de aço e do núcleo de concreto;

- Produção do concreto;

- Concretagem, adensamento e cura;

A seguir é descrita cada etapa de produção dos modelos.

\subsubsection{Confecção dos furos}

Foram confeccionados 6 furos de $18 \mathrm{~mm}$ de diâmetro na alma do perfil "U" simples para a passagem barras rosqueadas. Tal furação foi executada antes da soldagem dos perfis compondo uma seção quadrada.
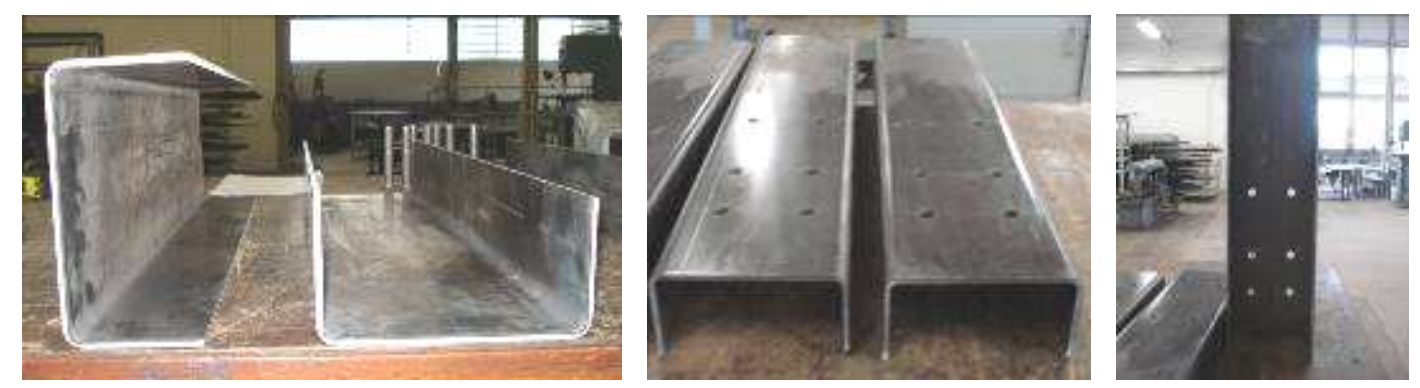

Figura 3.28. Perfis de aço "U" antes e depois da confecção dos furos.

\subsubsection{Soldagem dos conectores de cisalhamento}

Os conectores de cisalhamento tipo pino com cabeça e cantoneiras foram soldados ao longo da alma do perfil U, com solda tipo MIG de $8 \mathrm{~mm}$ de espessura de $8 \mathrm{~mm}$. 

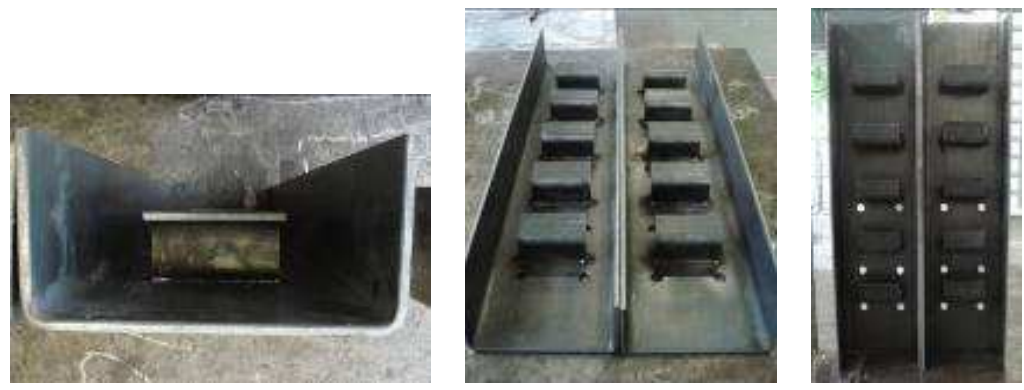

Figura 3.29. Confecção dos perfis com conector de cisalhamento tipo cantoneira.
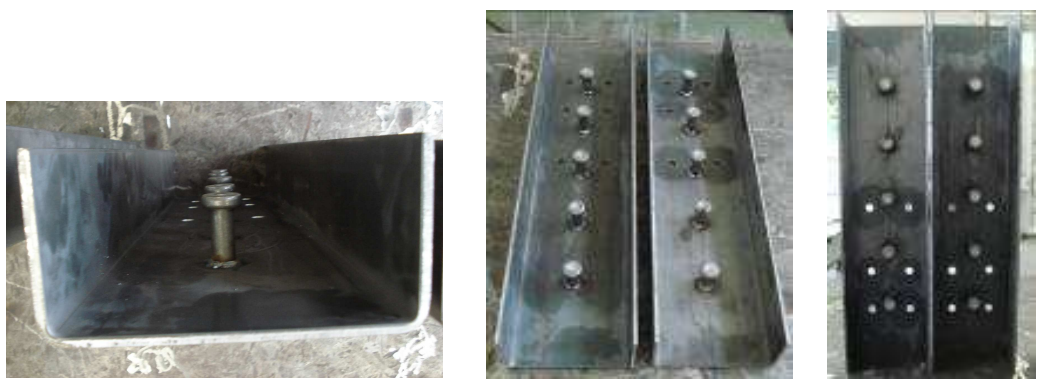

Figura 3.30. Confecção dos perfis com conector de cisalhamento tipo pino com cabeça.

\subsubsection{Instrumentação das barras rosqueadas}

Nas barras rosqueadas foram colados 2 extensômetros no meio da barra, de modo que ambos ficassem em faces diametralmente opostas (Figura 3.31).

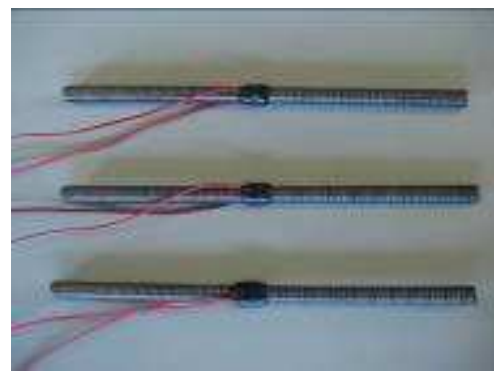

Figura 3.31. Instrumentação das barras rosqueadas. 


\subsubsection{Colocação das barras rosqueadas no pilar de aço}

Devido à instrumentação nas barras rosqueadas, foi necessária a colocação das mesmas na posição desejada antes do fechamento dos perfis, de forma a evitar a passagem das barras através dos furos já confeccionados.

\subsubsection{Confecção dos pilares metálicos}

Os pilares metálicos foram confeccionados a partir da soldagem de 2 perfis "U" simples. A solda utilizada para isto foi do tipo MIG com espessura de $8 \mathrm{~mm}$;

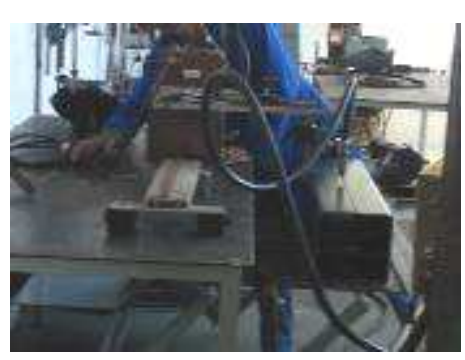

(a)

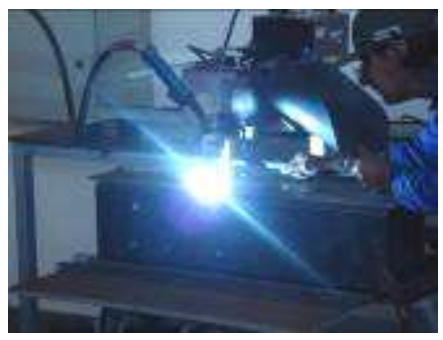

(b)

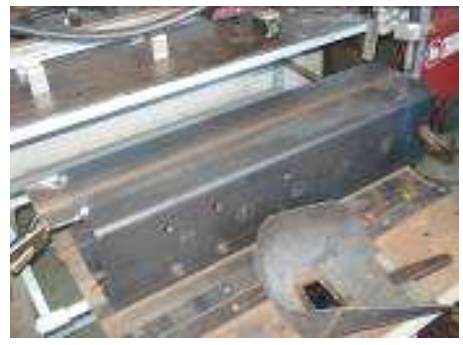

(c)

Figura 3.32. Confecção dos pilares metálicos. (a) Calibração da máquina de solda. (b) Soldagem dos perfis "U". (c) Perfis de aço soldados.

\subsubsection{Colocação das barras rosqueadas e chapas de aço}

Após a soldagem dos perfis, os modelos foram finalizados com a colocação das barras rosqueadas não instrumentadas e das chapas de aço.

\subsubsection{Instrumentação dos perfis de aço}

A Figura 2.33 apresenta todo o procedimento realizado para instrumentar o pilar aço. 


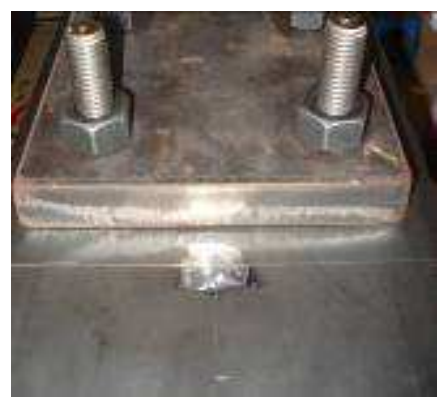

(a) Preparação da superfície.

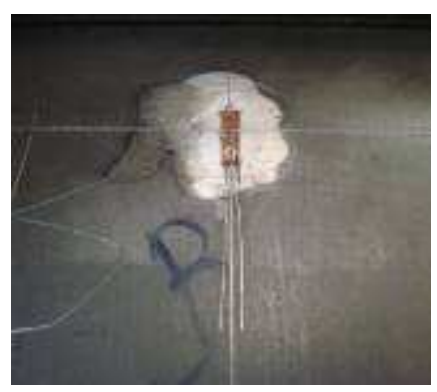

(d) Extensômetro colado.

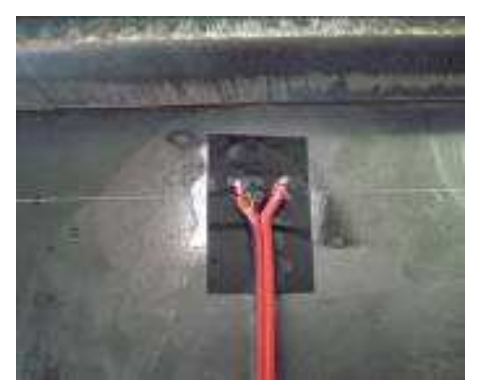

(g)

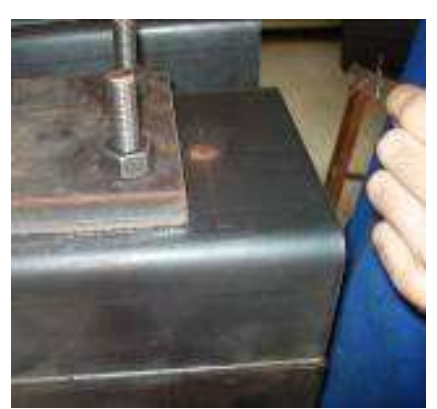

(b) Aplicação da cola.

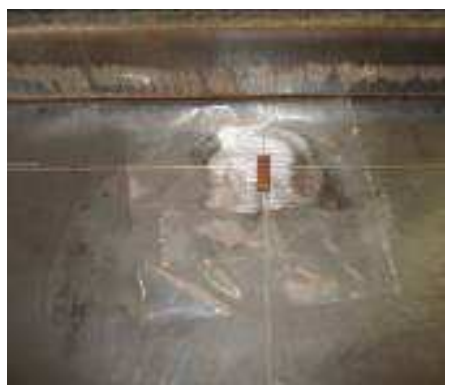

(e) Retirada do excesso de cola.

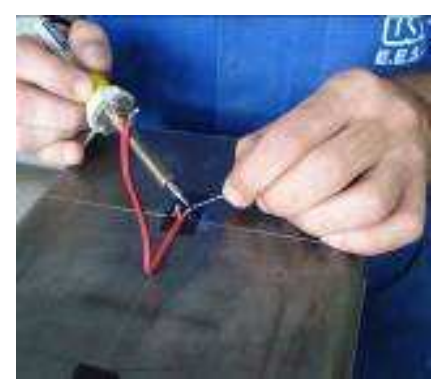

(h)

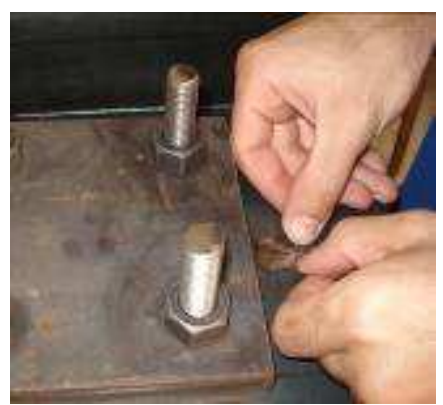

(c) Colagem do extensômetro.

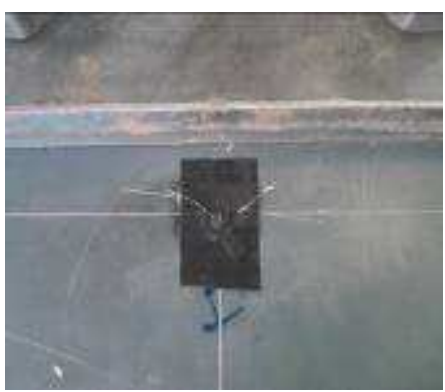

(f) Colocação de fita adesiva para proteger o extensômetro.

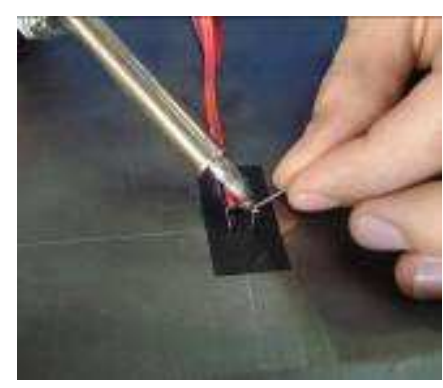

(i)

Colocação do fio para ligação nos canais do sistema de aquisição no ensaio.

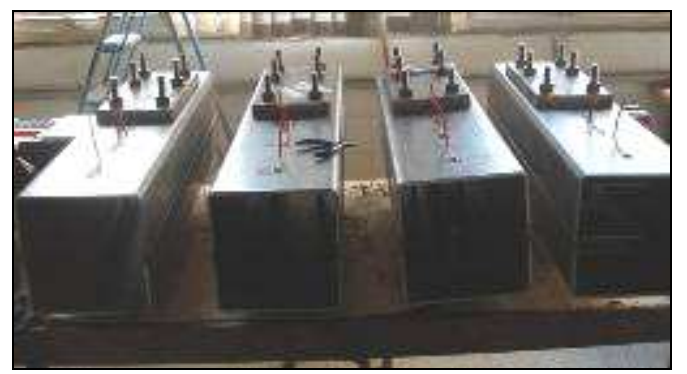

Figura 3.33. Confecção da instrumentação do perfil de aço. 
A Figura 3.34 apresenta, detalhadamente, o procedimento para instrumentação do núcleo de concreto do pilar preenchido.

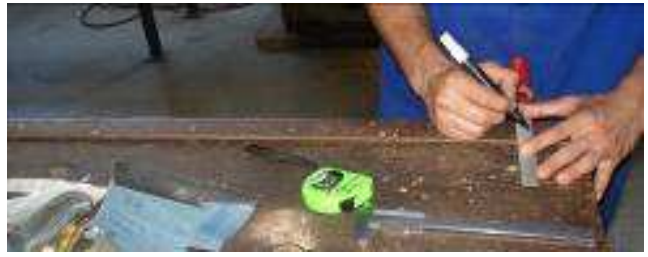

(a) Marcação dos pontos.

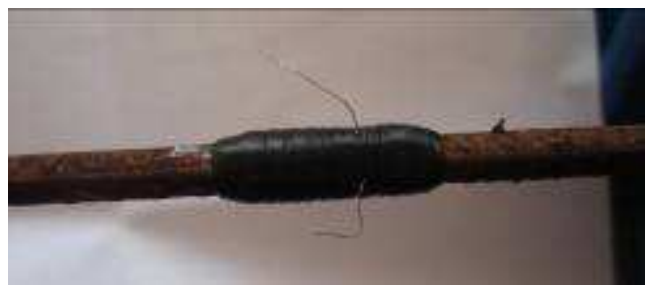

(b) Proteção do extensômetro.

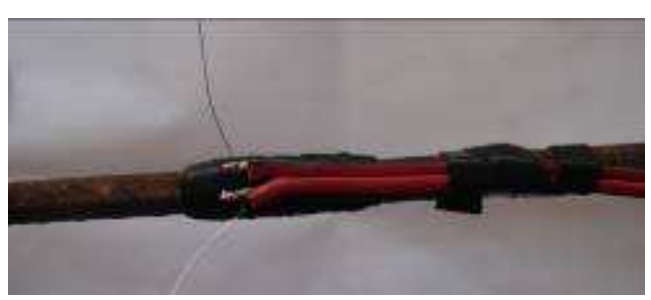

(c) Colocação do fio.

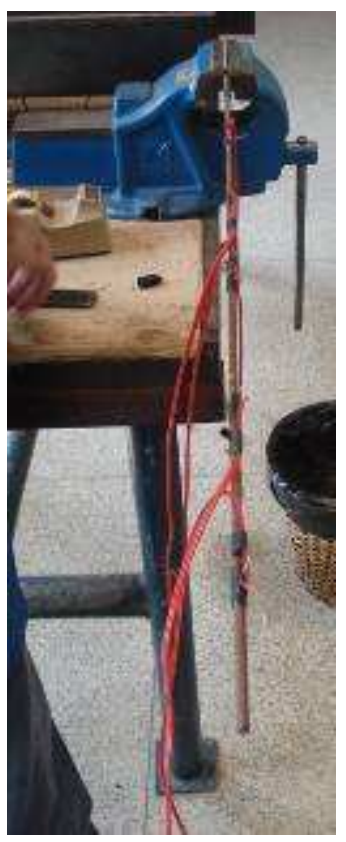

(d) Instrumentação da barra de aço concluída.

Figura 3.34. Instrumentação do núcleo de concreto.

\subsubsection{Produção do concreto}

Agregado graúdo, agregado miúdo, cimento, sílica e água foram misturados em betoneira comum a fim de se obter o concreto utilizado no preenchimento do perfil tubular de aço (figura 3.35). 

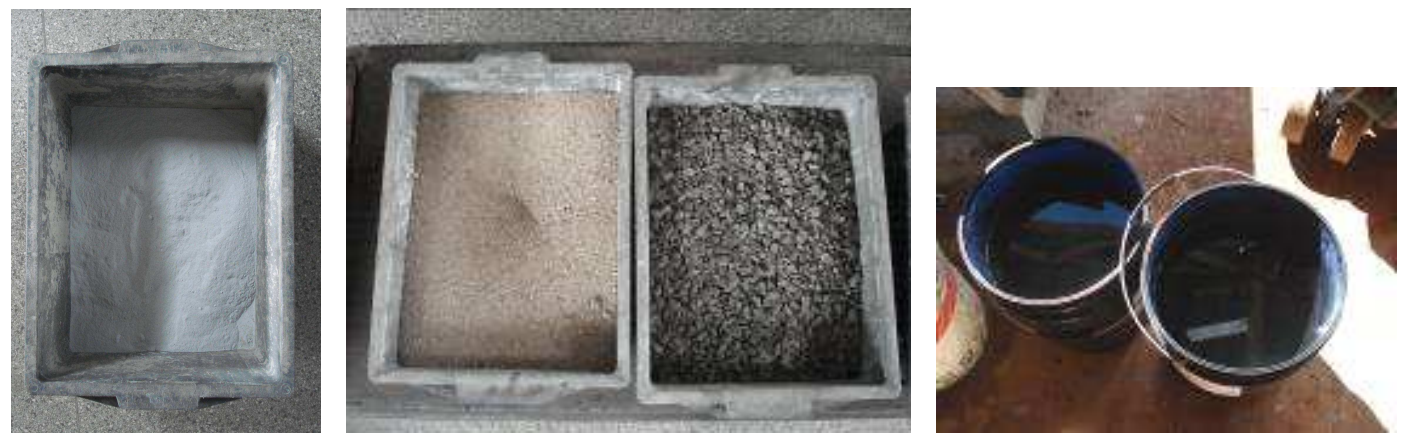

Figura 3.35. Materiais empregados na confecção do concreto.
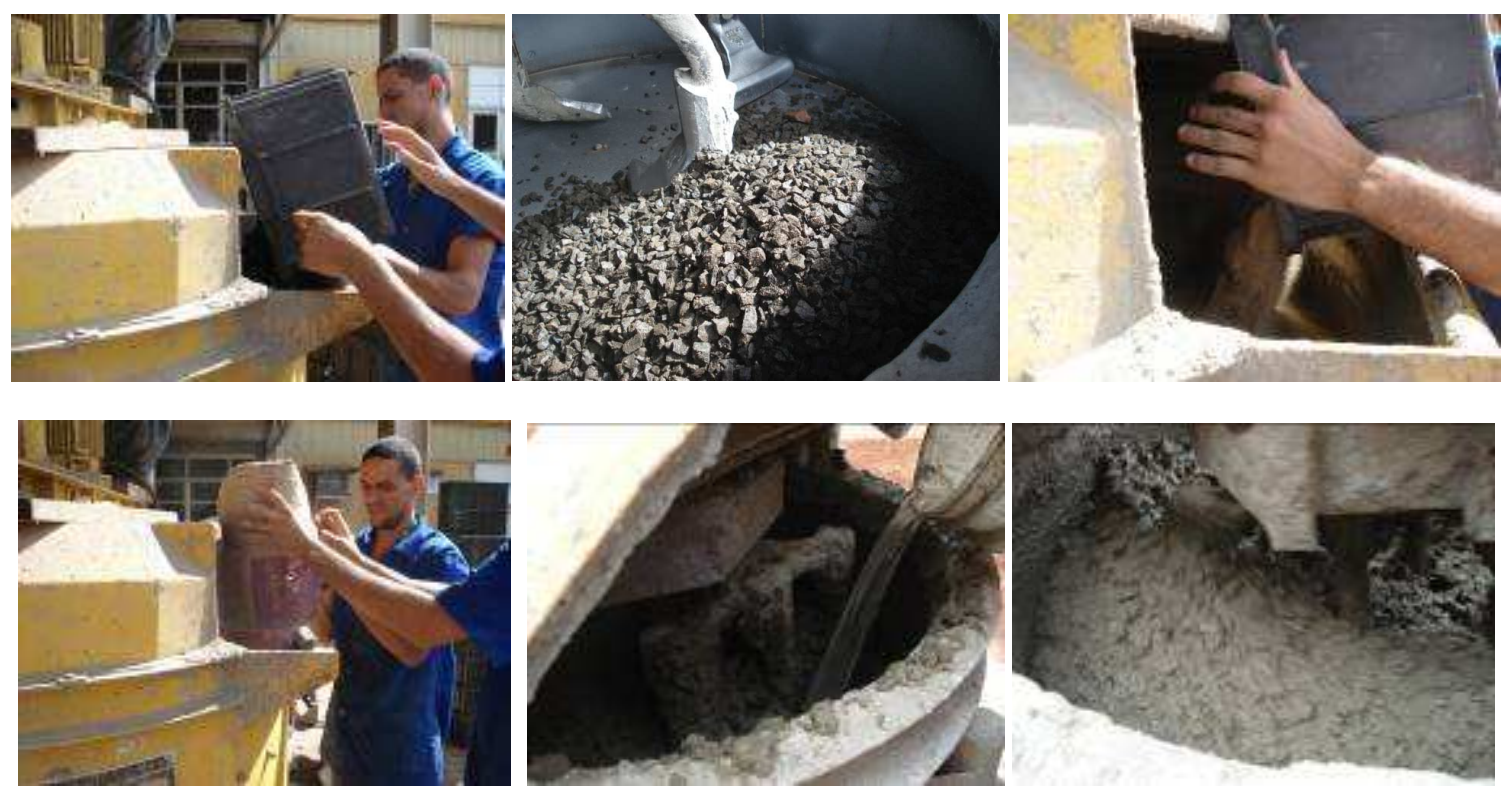

Figura 3.36. Colocação dos materiais na betoneira para a produção do concreto.

\subsubsection{Concretagem, adensamento e cura}

A Figura 3.37 ilustra as etapas de concretagem, adensamento e cura dos modelos de ligação a serem ensaiados. O adensamento foi feito com vibrador de agulha e a cura do concreto foi feita com o auxílio de uma espuma umedecida com água. 

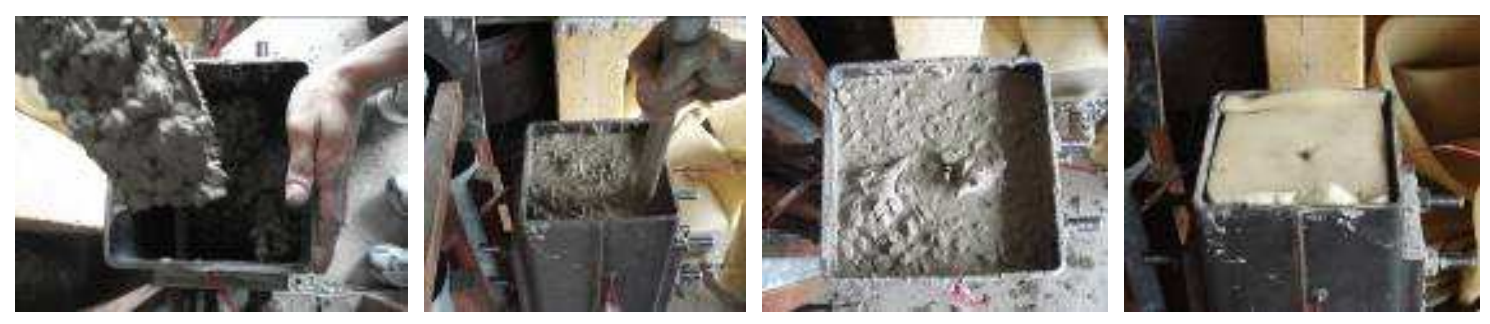

Figura 3.37. Concretagem, adensamento e cura.

Durante a concretagem, uma folga de $25 \mathrm{~mm}$ foi deixada nas regiões superior e inferior dos pilares preenchidos. A folga inferior foi conseguida colocando uma placa de EPS com $25 \mathrm{~mm}$ de espessura. E a folga superior foi facilmente obtida durante a concretagem, que não foi levada até à face do perfil tubular de aço. A folga superior tem o objetivo de permitir a aplicação do carregamento unicamente no concreto e a inferior, de permitir a colocação dos transdutores de deslocamentos.
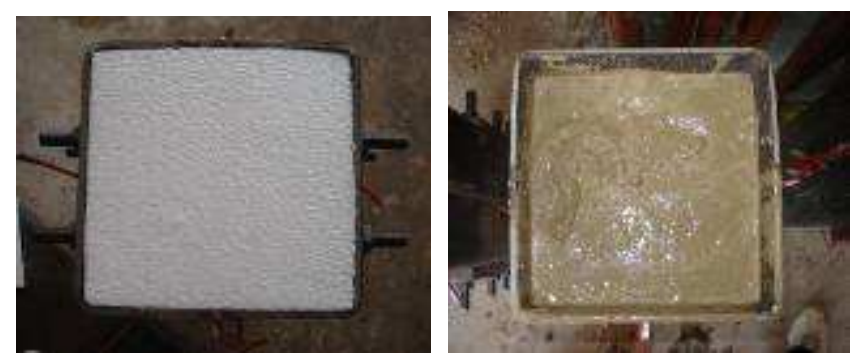

Figura 3.38. Folga nas extremidades do pilar preenchido.

O preenchimento do perfil tubular e a moldagem dos corpos de prova foram realizados simultaneamente. A cura dos corpos de prova foi feita em câmara úmida.

\subsection{Esquema de ensaio}

A investigação experimental foi realizada por meio de ensaios do tipo push-out no Laboratório de Estruturas da Escola de Engenharia de São Carlos, com aplicação do 
carregamento vertical diretamente no núcleo de concreto; nas chapas de aço que representam a ligação viga-pilar foram aplicadas as reações de apoio.

O objetivo do ensaio push-out realizado foi o de promover um deslocamento relativo entre o núcleo de concreto e o perfil de aço, de forma a provocar o cisalhamento das barras rosqueadas da ligação.

A Figura 3.39 apresenta o esquema de ensaio empregado no estudo experimental.
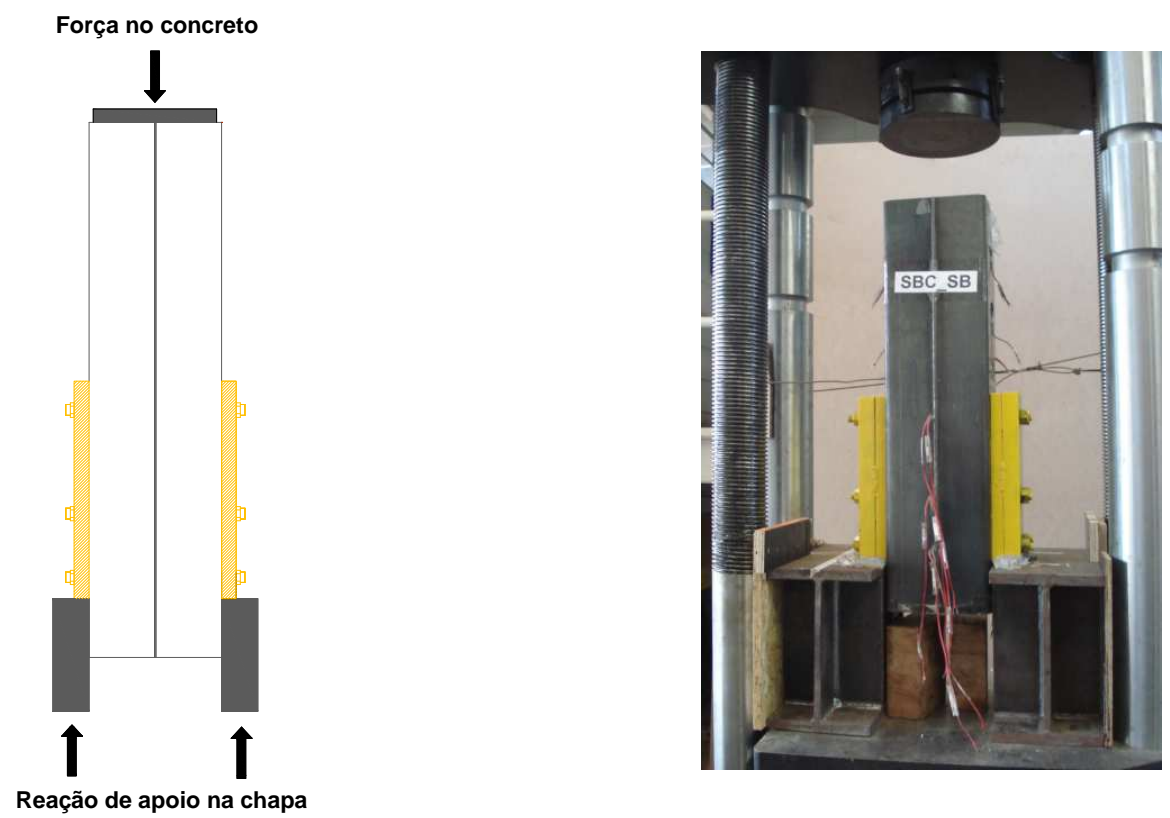

Figura 3.39. Esquema de ensaio push-out.

As chapas foram apoiadas em perfis "I" enrijecidos, que aplicavam reações de apoio nas chapas de ligação.

As superfícies de aplicação do carregamento e contato das chapas com as vigas de apoio foram regularizadas com massa adesiva plástica e, posteriormente, foi verificado o prumo dos modelos empregando nível de bolha (Figura 3.40). 

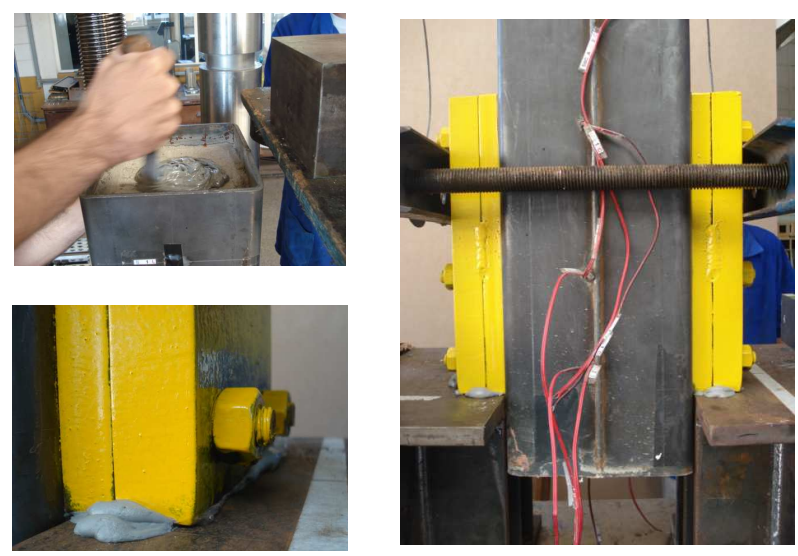

Figura 3.40. Regularização e nivelamento das superfícies.

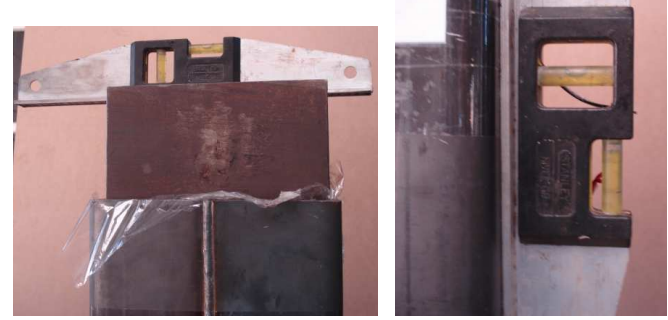

Figura 3.41. Verificação do nivelamento das superfícies.

Para aplicação do carregamento no núcleo de concreto foi empregado um bloco de aço conforme ilustrado na Figura 3.42.
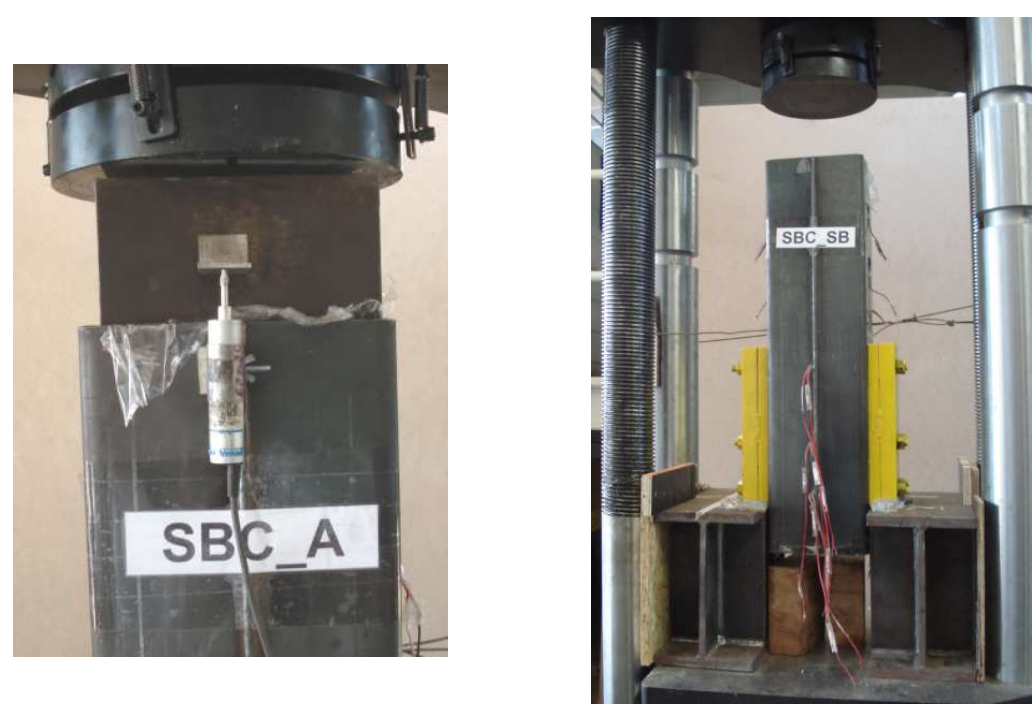

Figura 3.42. Aplicação do carregamento no núcleo de concreto.

Os ensaios foram realizados na Máquina de Ensaio Servo-Hidráulica, marca Instron, modelo 5595 - $300 \mathrm{HVL}$, com capacidade de 1500 kN e que permite a aplicação de forças com controle de deslocamento do atuador. A velocidade de ensaio foi de $0,005 \mathrm{~mm} / \mathrm{s}$. 
Antes da realização dos ensaios, todas as barras rosqueadas foram protendidas conforme orientação da ABNT NBR 8800, tendo sido aplicado um torque de 260 Nm, empregando torquímetro da marca Gedore Flexo-click nº 4556.

Para maior segurança, durante o ensaio, foram utilizadas chapas de madeira para encunhar o modelo de forma que, quando houvesse a ruptura das barras rosqueadas, não ocorresse movimentação brusca dos perfis de apoio e nem queda dos modelos sobre os dispositivos de ensaio. Esse cuidado fez-se necessário uma vez que a região de ligação, mais precisamente, as barras rosqueadas deveriam apresentar ruptura por cisalhamento, que é uma ruptura do tipo brusca.

\subsection{Análise dos Resultados Experimentais}

Para análise dos resultados experimentais dos três modelos físicos ensaiados, os dados obtidos são apresentados na forma de gráficos, como segue:

- Força aplicada versus Deslocamento do núcleo de concreto;

- Força aplicada versus Deformação do núcleo de concreto;

- Força aplicada versus Deformação do perfil tubular de aço;

- Força Aplicada versus deformação axial das barras rosqueadas.

Dessa forma, a seguir são apresentados os gráficos gerados a partir dos dados dos ensaios, juntamente com uma discussão, análise e comparação dos resultados, considerando os três modelos investigados. 


\subsubsection{Modo de Falha e Valores Máximos}

Os três modelos apresentaram ruptura por cisalhamento da barra redonda rosqueada, como se esperava. Na Figura 3.43 pode ser verificada a ruptura dos modelos ensaiados.

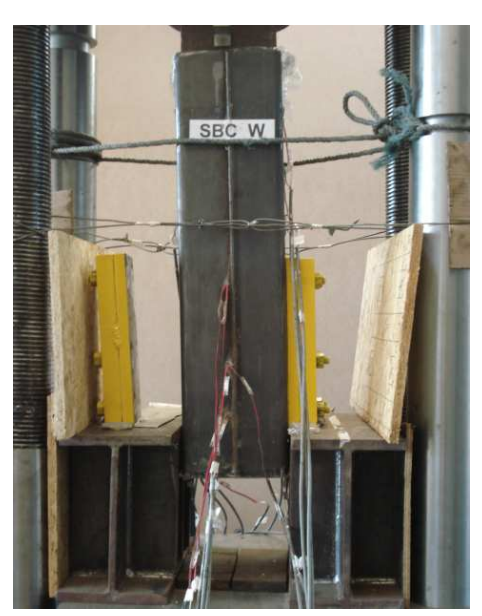

(a)
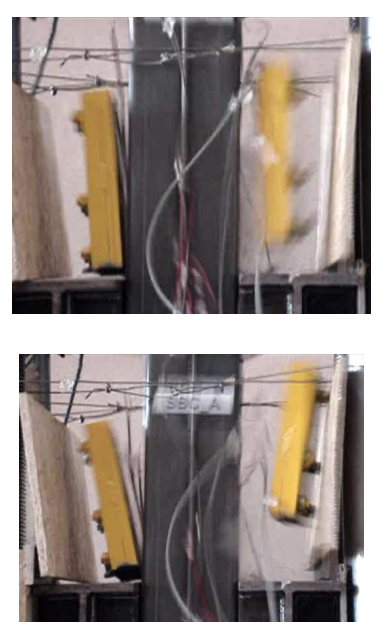

(b)

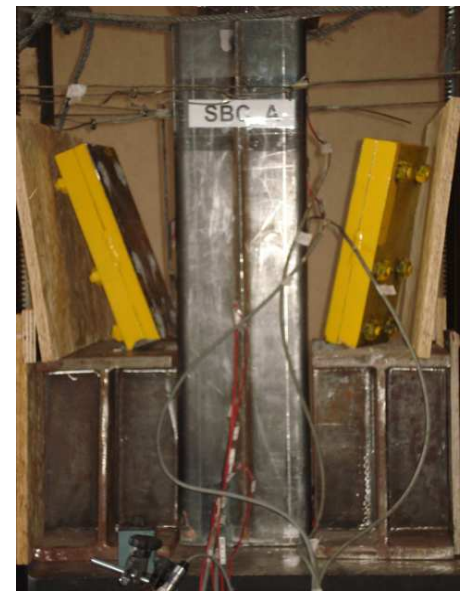

(c)

Figura 3.43. Configuração do modelo após a ruptura das barras rosqueadas por cisalhamento. (a) Modelo SBC_W. (b) e (c) Modelo SBC_A.

A força máxima de ruptura alcançada em cada ensaio foi de: 969,24 kN para o modelo SBC_W, $984,84 \mathrm{kN}$ para o modelo SBC_SB e $958,90 \mathrm{kN}$ para o SBC_A.

O comportamento dos modelos de ligação quanto ao deslocamento vertical registrado pela máquina de ensaios é apresentado na Figura 3.43, em que se observa uma equivalência nos valores máximos alcançados. 


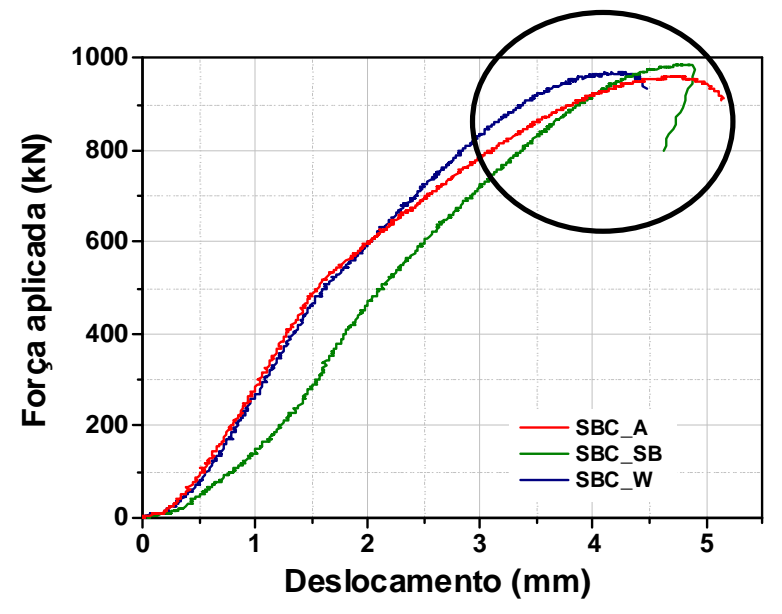

(a)

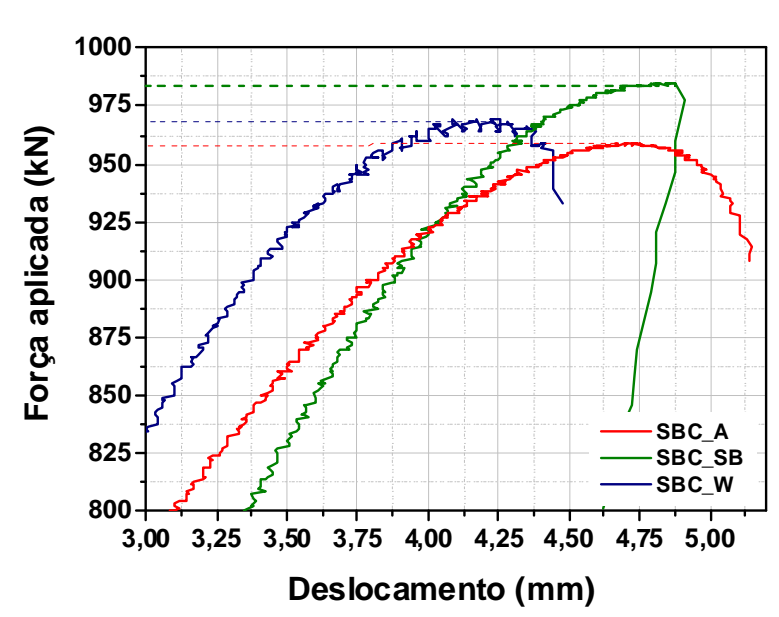

(b)

Figura 3.44. (a) Comportamento Força Aplicada versus Deslocamento do Pistão da máquina de ensaios. (b) Zoom da região circular de (a)

\subsubsection{Comportamento Força Aplicada versus Deslocamento do Núcleo de Concreto - deslizamento relativo aço-concreto}

Os deslocamentos relativos entre o perfil de aço e o núcleo de concreto foram obtidos por meio de transdutores de deslocamento localizados, nas partes superiores e inferiores do perfil de aço. Uma terceira medida de deslocamento foi obtida pelo próprio sistema de aquisição de dados e representa o deslocamento do pistão ou atuador da máquina de ensaio.

É importante ressaltar que antes de chegar ao final do ensaio, os transdutores inferiores foram retirados para evitar qualquer dano durante a ruptura das barras rosqueadas. Dessa forma, como toda a análise foi baseada nas leituras dos deslocamentos registrados pelos transdutores e como não podem ser feitas considerando os máximos deslocamentos alcançados, os valores máximos registrados não correspondem aos máximos que seriam atingidos ao fim do ensaio. Assim, as curvas geradas servem apenas para uma análise comportamental. 
As Figuras 3.45, 3.46 e 3.47 apresentam os gráficos de força aplicada versus deslocamento do núcleo de concreto para cada um dos modelos ensaiados, apresentando os deslocamentos registrados pelos transdutores superiores e inferiores e pelo pistão.

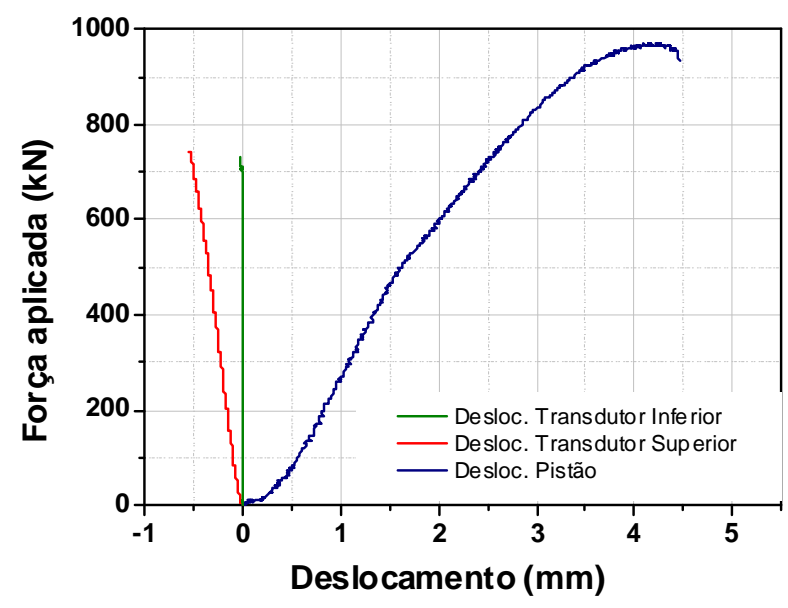

Figura 3.45. Força aplicada versus Deslocamento no núcleo de concreto modelo SBC_W.

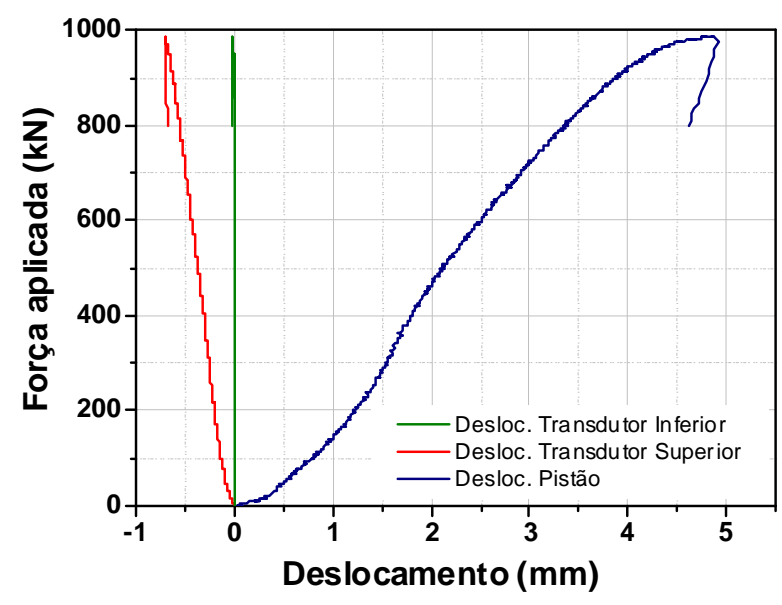

Figura 3.46. Força aplicada versus Deslocamento no núcleo de concreto modelo SBC_SB.

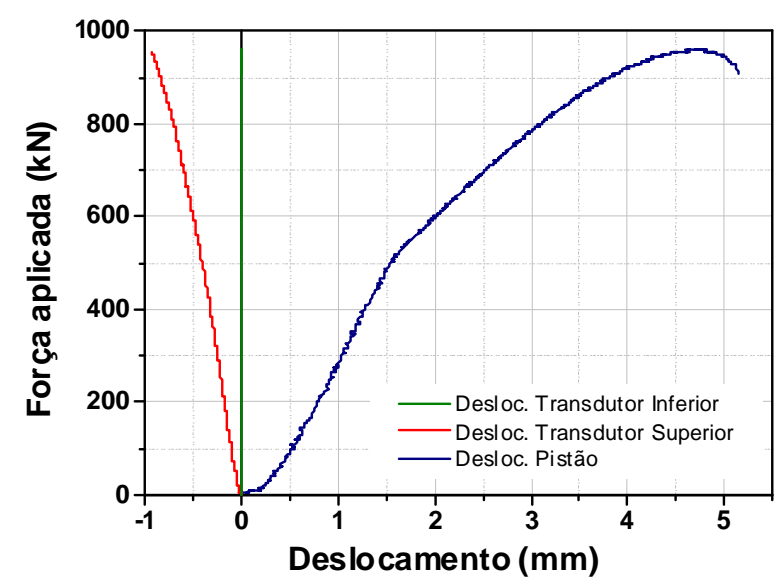

Figura 3.47. Força aplicada versus Deslocamento no núcleo de concreto modelo SBC_A. 
Observando a Figura 3.48b, que traz os deslocamentos medidos na face inferior do núcleo de concreto (doravante denotado por NC), verifica-se que, para os três modelos ensaiados, não houve deslocamento relativo significativo entre o NC e o perfil de aço, se comparado com os deslocamentos registrados pelos transdutores superiores (Figura 3.48 a), que são bem maiores.

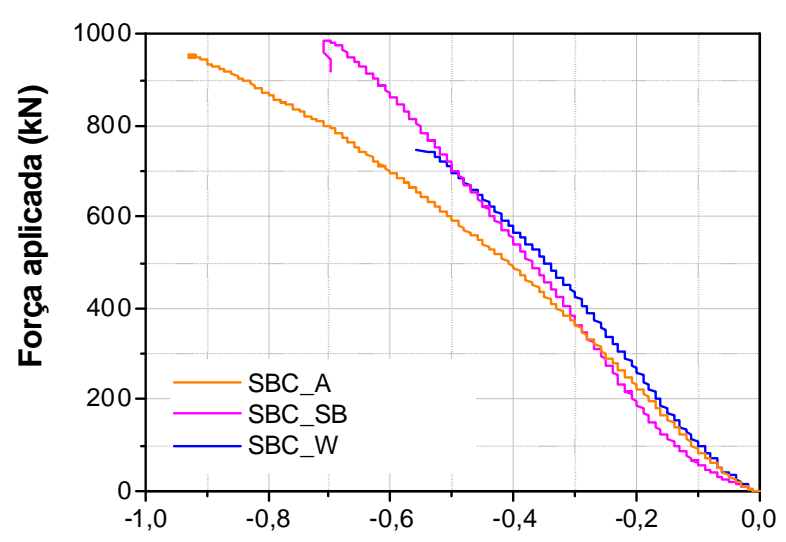

Deslocamento do NC - Transdutor Superior $(\mathrm{mm})$

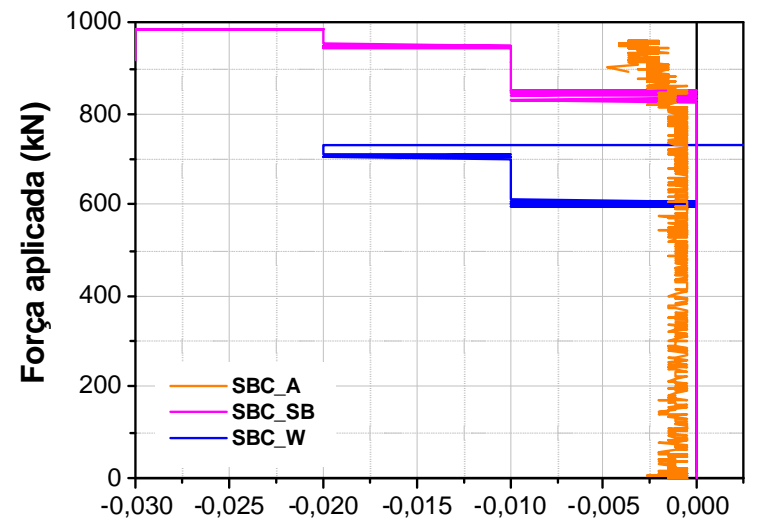

Deslocamento do NC - Transdutor Inferior (mm)

(b)

Figura 3.48. Comportamento Força versus deslocamento no núcleo de concreto registrado pelos transdutores de deslocamento.

Verifica-se também que no modelo SBC_W (sem conectores), o escorregamento do NC tem início para um carregamento da ordem de $600 \mathrm{kN}$, para o qual se verifica um deslocamento de aproximadamente $-0,01 \mathrm{~mm}$. Para o modelo SBC_SB (com conectores tipo pino com cabeça) a força necessária para produzir um deslizamento de aproximadamente $-0,01 \mathrm{~mm}$ corresponde a $825 \mathrm{kN}$. Já para o modelo SBC_A (com cantoneiras), o deslocamento registrado chega a -0,0025 mm para o carregamento de $825 \mathrm{kN}$.

A partir destes resultados, verifica-se que as barras rosqueadas impedem consideravelmente o deslocamento vertical do NC e, quando associada aos conectores de cisalhamento, essa restrição ao escorregamento torna-se ainda mais significativa. 
Quanto à associação com conectores tipo stud bolt, observa-se que o primeiro escorregamento é postergado para um nível de força maior (de 600 para 825 kN) (Figura 3.49a) que o observado no modelo sem conectores (SBC_W). Entretanto, a variação dos deslocamentos relativos ( $\Delta$ desloc) é a mesma nos modelos SBC_W e SBC_SB (Figura 3.49b).

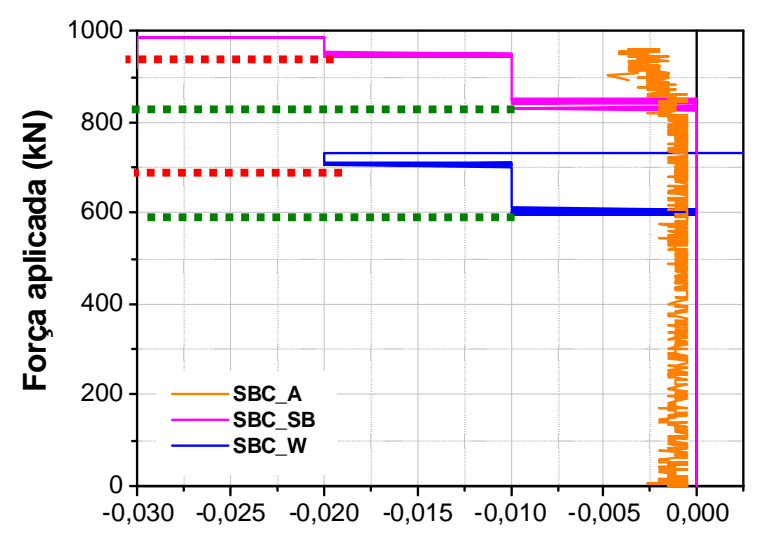

Deslocamento do NC - Transdutor Inferior (mm)

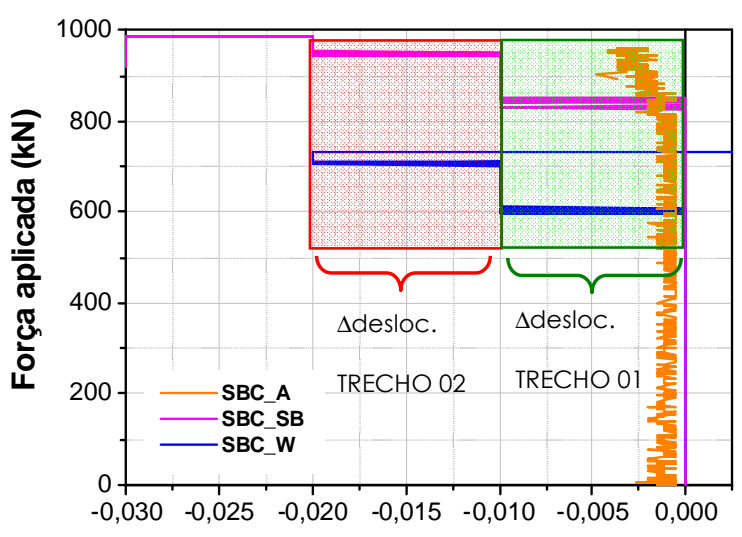

Deslocamento do NC - Transdutor Inferior (mm)

(a)

(b)

Figura 3.49. Comparação entre os deslocamentos relativos nos modelos SBC_W e SBC_SB registrados pelo transdutor inferior.

Todavia, quando se compara o comportamento dos modelos SBC_A e SBC_W, verifica-se que as cantoneiras usadas neste trabalho são elementos mais eficientes que os conectores tipo pino com cabeça na função de evitar o escorregamento do núcleo de concreto, sendo muito positiva a sua associação com as barras rosquedas.

Entretanto, como é possível que o modelo SBC_A apresente um deslocamento tão pequeno na parte inferior (transdutor inferior), quando o transdutor superior apresenta os maiores valores de deslocamento registrados entre os três modelos?

Acredita-se que ocorra esmagamento do NC na região das cantoneiras, de forma que as cantoneiras trabalhem como um mecanismo eficiente de transmissão de esforços de cisalhamento. Para tanto, é necessário analisar os gráficos de Força aplicada versus Deformação do núcleo de concreto, que é apresentado no próximo item. 


\subsubsection{Comportamento Força versus Deformação do Núcleo de Concreto}

Em função do modo de falha observado e considerando que o carregamento é aplicado apenas no núcleo de concreto (NC) do pilar preenchido, grande parte da força aplicada é absorvida pelo concreto. Isto pode ser comprovado ao observar a Figura 3.50 na qual são mostradas as deformações axiais no concreto, em vários pontos ao longo da altura do pilar (Figura 3.50 e 3.51).
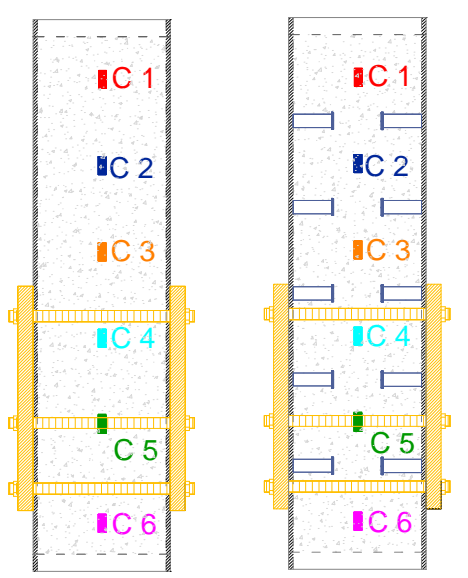

Figura 3.50. Posição dos extensômetros no núcleo de concreto.

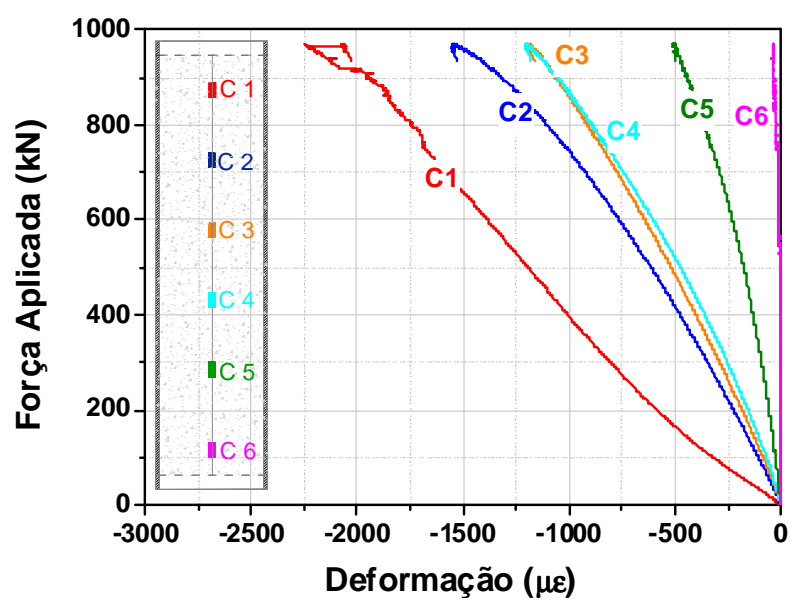

Figura 3.51. SBC_W: Comportamento Força aplicada versus Deformação do Núcleo de Concreto.

Observa-se que, mantendo o mesmo nível de carregamento, quanto mais próximo da região de ligação (avançando do extensômetro $\mathrm{Cl}$ ao C6), menores são as deformações no concreto. Isso ocorre porque, na região de ligação a força é absorvida, quase que na totalidade, pelas barras rosqueadas, por isso a deformação no concreto é pequena. 


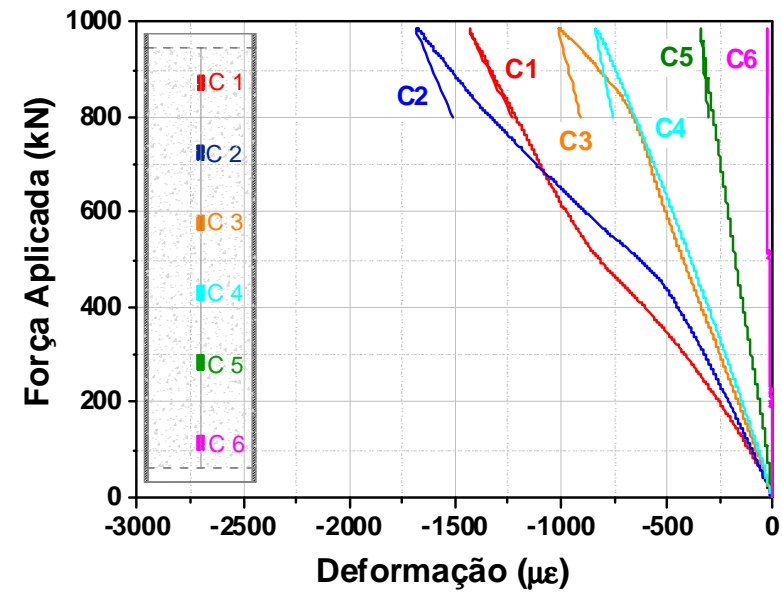

Figura 3.52 . SBC_SB: Comportamento Força aplicada vs. Deformação do Núcleo de Concreto.

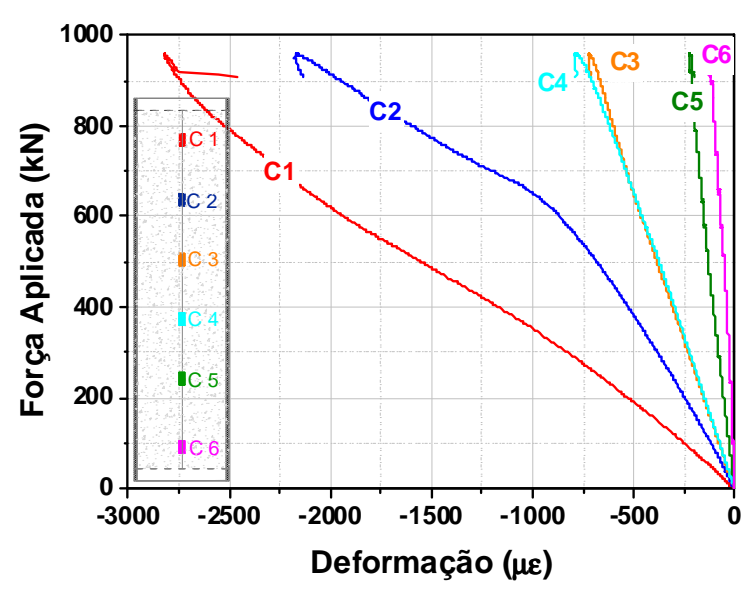

Figura 3.53. SBC_A: Comportamento Força aplicada vs. Deformação do Núcleo de Concreto.

Desse modo, verifica-se que, para um mesmo nível de carregamento, o concreto na região do extensômetro $\mathrm{Cl}$ apresenta as maiores deformações, seguido pelo extensômetro C2, em seguida as deformações nos extensômetros C3 e C4 são praticamente coincidentes (as curvas se sobrepõem) e, por fim, os extensômetros C5 e C6.

As leituras registradas pelos extensômetros C1 e C2 são elevadas, haja vista que tal ponto se localiza bem próximo da região de aplicação do carregamento. No modelo SBC_A, o concreto na região instrumentada é bastante solicitado se comparado aos demais modelos, pois quase não há movimentação do NC e, dessa forma, o concreto torna-se mais comprimido e as deformações chegam a atingir valores próximos dos correspondentes ao esmagamento do concreto.

Observa-se que nos três modelos as curvas referentes às leituras dos extensômetros C3 e C4 são equivalentes. Entretanto, entre os modelos há uma diferença na inclinação das curvas. As curvas do modelo SBC_W apresentam inclinação menor que dos modelos SBC_SB e SBC_A. Acredita-se que essa diminuição da deformação do concreto nos modelos SBC_SB e SBC_A deve-se ao fato de que os esforços que eram absorvidos pelo NC passam a ser transferidos para o perfil de aço. 
Assim como acontece um aumento na inclinação nas retas referentes aos pontos C3 e C4 nos modelos SBC_A e SBC_SB, também acontece com o comportamento registrado pelo extensômetro C5, localizado na região de ligação.

Desse modo, conclui-se que as leituras dos extensômetros da região de ligação (C3, C4 e C5) apresentam significativa mudança quanto à presença de conectores de cisalhamento, verificando que os conectores tipo cantoneira apresentam maior eficiência. Para tanto, é necessário observar o comportamento dos extensômetros no perfil de aço, para verificar se a diminuição da deformação constatada no NC está realmente relacionada à transferência de esforços para o perfil e ao aumento da solicitação nas barras rosqueadas.

O concreto na região do extensômetro C6 apresenta deformação axial muito pequena se comparada com as deformações registradas nos demais extensômetros. Dentre estes valores pequenos observados para os três modelos ensaiados, destaca-se que o modelo SBC_A apresenta as maiores deformações no extensômetro C6 (Figura 3.52).

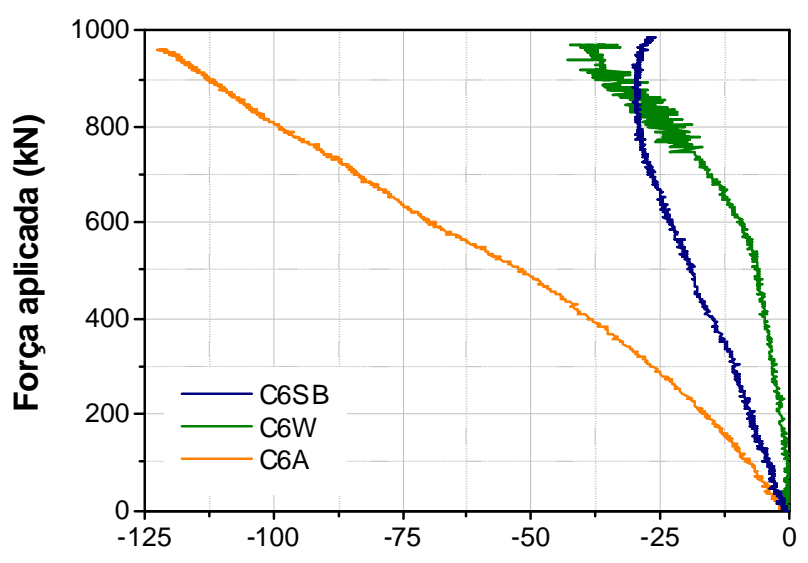

Deformação concreto extensômetro C6 ( $\mu \varepsilon)$

Figura 3.54. Deformações no extensômetro C6 posicionado no núcleo de concreto. 


\subsubsection{Comportamento Força Aplicada versus Deformação do Perfil de Aço}

A Figura 3.55 mostra a localização dos extensômetros no perfil de aço.
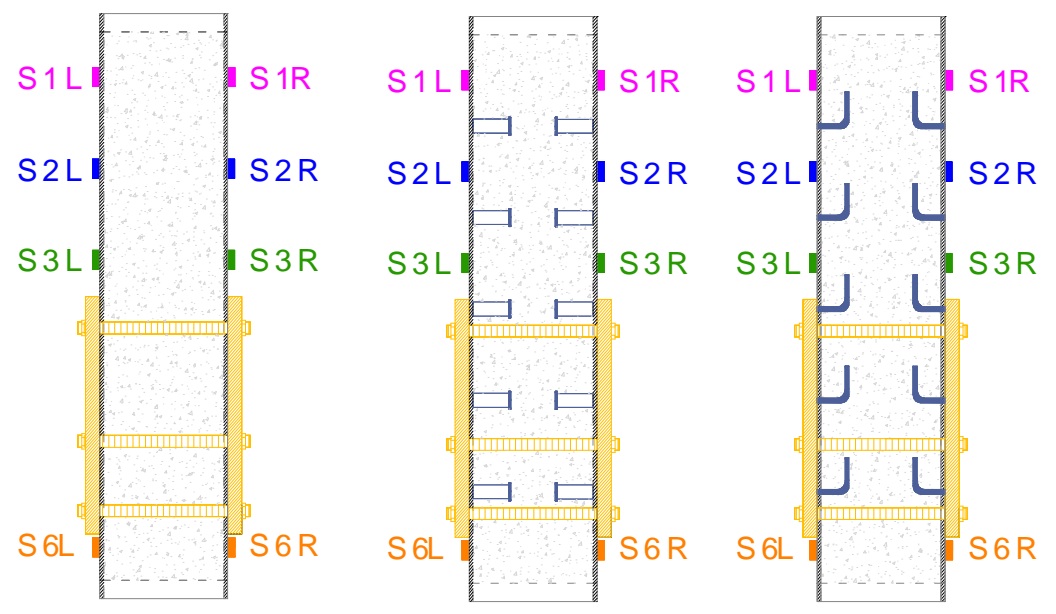

Figura 3.55. Arranjo dos extensômetros nos modelos ensaiados.

As Figuras $3.56,3.57$ e 3.58 apresentam os gráficos de força aplicada versus deformação no perfil de aço para os modelos SBC_W, SBC_SB e SBC_A, respectivamente.

Na análise dos dados referentes às leituras de deformação no perfil de aço, foram desprezados os valores obtidos pelos extensômetros S6L e S6R, haja vista que estavam posicionados próximos ao bloco de aço em que se aplicavam as reações de apoio. Devido a esta proximidade, os valores medidos foram influenciados por esse contato e apresentaram valores incompatíveis. Mesmo que não houvesse o contato com o bloco de aço, como os extensômetros estavam localizados abaixo da ligação, não registrariam deformações significativas nessa região. 

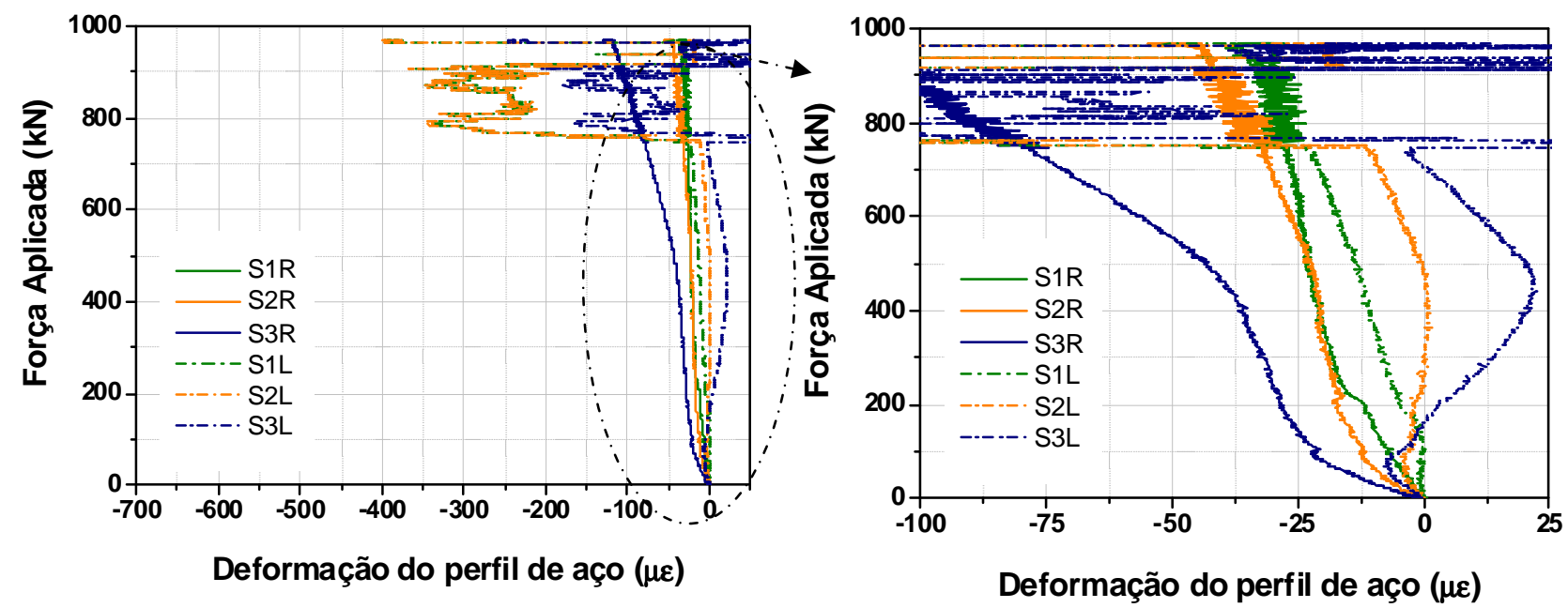

Figura 3.56. SBC_W: Comportamento Força Aplicada versus Deformação no perfil de aço.

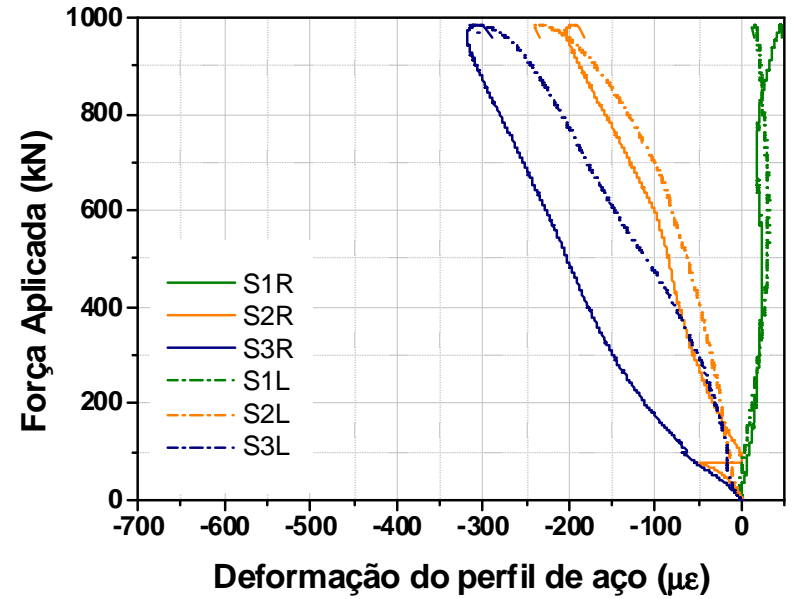

Figura 3.57. SBC_SB: Comportamento Força aplicada versus Deformação no perfil.

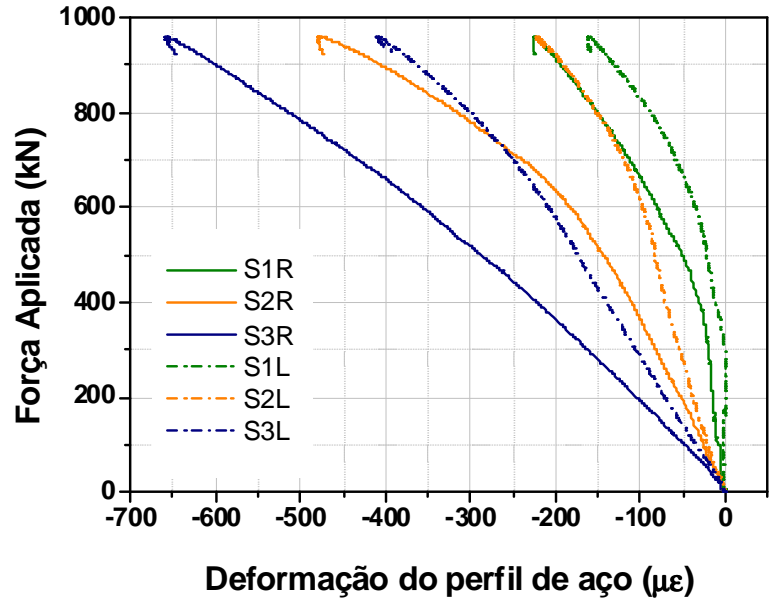

Figura 3.58. SBC_A: Comportamento Força aplicada versus Deformação no perfil.

Observa-se, que nos três modelos, os extensômetros S3R e S3L apresentam as maiores deformações. Dentre os modelos ensaiados, o modelo SBC_A é o que apresenta maiores deformações, o que leva a concluir que as cantoneiras apresentam maior eficiência na transferência dos esforços do NC para o perfil de aço, se comparada aos conectores tipo pino com cabeça.

O gráfico apresentado na Figura 3.59 corresponde a uma análise comparativa dos três modelos no que diz respeito à leitura registrada pelo extensômetro S3R. A partir desta 
comparação, verifica-se que quanto menor a inclinação da curva força vs. deformação, maior a deformação obtida no perfil de aço, isto para um mesmo nível de força, o que corresponde a dizer que: se a deformação no perfil de aço é maior, a transferência de esforços do núcleo de concreto para o perfil e o mecanismo de transferência são mais eficientes.

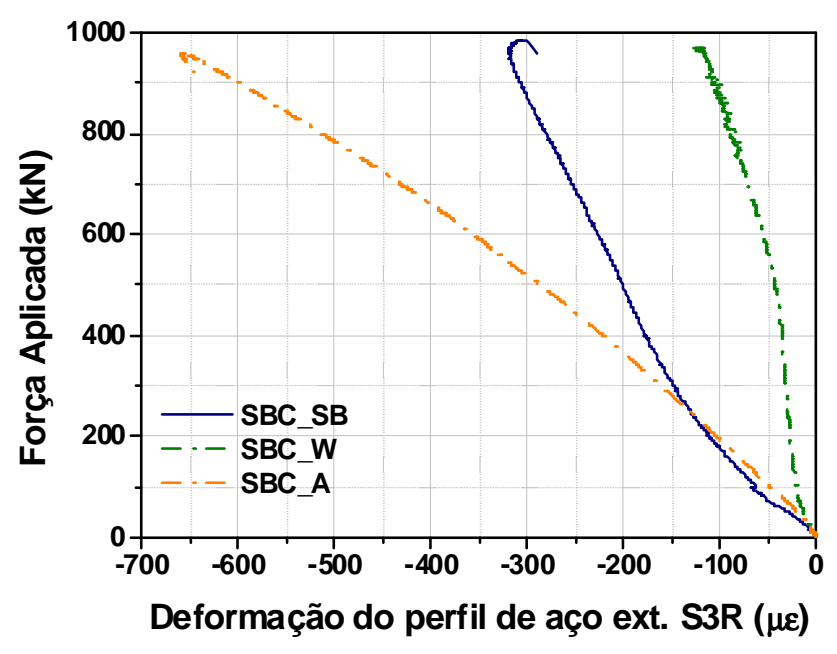

Figura 3.59. Análise da inclinação das retas referentes às leituras do extensômetro S3R.

Como esperado, os conectores de cisalhamento tipo cantoneira apresentam maior eficiência na transferência dos esforços de cisalhamento em todos os pontos ao longo do perfil de aço em que foram feitas as leituras, sendo mais expressivo na região da ligação, como se observa nas análises dos gráficos.

Além disso, observa-se nos três modelos ensaiados que, quanto mais próximo da região de ligação maior as leituras de deformação registradas pelos extensômetros.

Nos estágios finais de carregamento ocorre um aumento das deformações de forma mais acentuado no modelo SBC_A, o que não se verifica nos demais modelos.

Nos três modelos ensaiados, verifica-se também que as deformações no lado direito não são iguais àquelas registradas do lado esquerdo, mas em todos os casos, as deformações do lado direito são maiores. A explicação para tal fato pode ser: a aplicação 
do carregamento não foi centrada e/ou influência das imperfeições geométricas do perfil e dos conectores.

No modelo SBC_W, o perfil de aço não apresenta deformações tão expressivas como ocorre nos demais modelos (SBC_A e SBC_SB). No caso do modelo SBC_W, a força vertical aplicada no núcleo de concreto é transferida diretamente da viga (representada pela chapa de extremidade) para as barras rosqueadas imersos no NC. Os mecanismos naturais de aderência (adesão, mecânica e atrito) existentes não são suficientes para promover uma transferência de esforços de cisalhamento do núcleo de concreto para o perfil de aço.

As deformações no perfil de aço são muito pequenas quando comparadas às do núcleo de concreto. Acredita-se que, se forem empregados mais conectores de cisalhamento, provavelmente essas deformações tenderiam a se aproximar da ordem de grandeza daquelas registradas no NC. Outro fato importante é que o carregamento é aplicado diretamente no NC e, portanto, as deformações no concreto serão sempre maiores que no perfil de aço.

\subsubsection{Comportamento Força versus Deformação nas barras rosqueadas}

Nas barras rosqueadas da ligação, embora sejam mobilizados durante a transferência de esforços da viga para a ligação, os extensômetros não registraram valores expressivos de deformação (Figuras 3.60, 3.61 e 3.62) quando comparados às deformações registradas no núcleo de concreto e no perfil de aço. Esses registros pequenos podem ser explicados pela forma como os extensômetros foram posicionados, ou seja, medindo as deformações axiais, que não são predominantes. Vale lembrar que as barras rosqueadas são solicitadas predominantemente ao cisalhamento. As Figuras 3.60, 3.61 e 3.62 apresentam o comportamento das barras rosqueadas. 


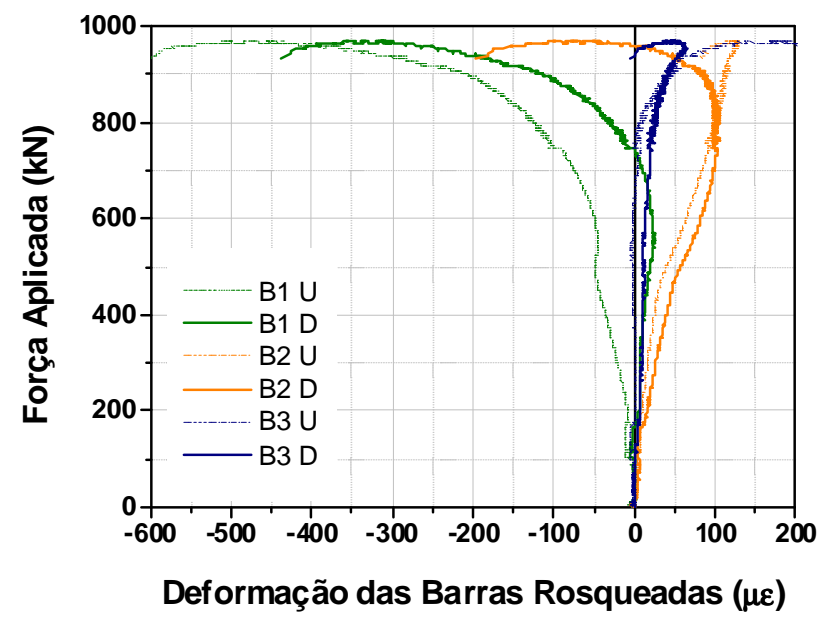

Figura 3.60. SBC_W: Comportamento Força aplicada versus Deformação axial nas barras rosqueadas.

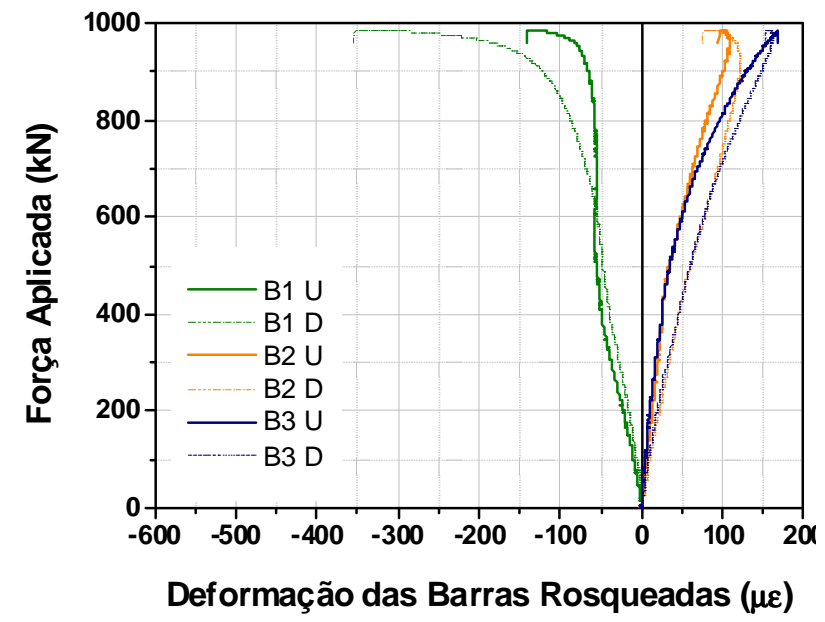

Figura 3.61. SBC_SB: Comportamento Força aplicada versus Deformação axial nas barras rosqueadas.

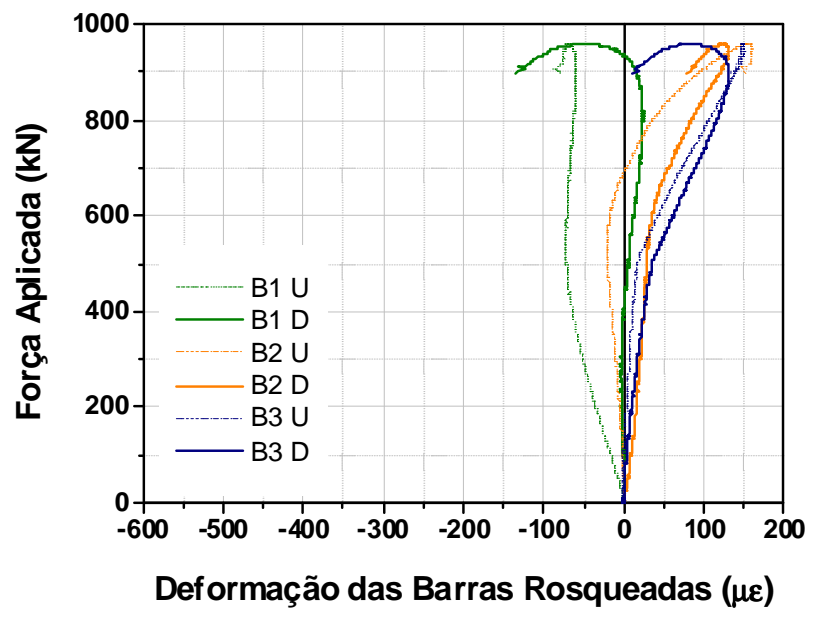

Figura 3.62. SBC_A: Comportamento Força aplicada vs. Deformação axial nas barras rosqueadas. 


\subsection{Comentários Finais}

Quando o carregamento é aplicado no NC, as forças de cisalhamento são transferidas para perfil de aço por meio dos mecanismos de aderência. Quando a aderência é rompida e não há conectores de cisalhamento, inicia-se o deslizamento do NC, e esse passa a mobilizar as barras rosqueadas, e as reações de apoio na chapa e deformações de compressão no NC se tornam expressivas. E o processo continua até que ocorra a ruptura das barras rosqueadas da ligação, por cisalhamento.

Se o carregamento fosse aplicado na seção mista, a reação na chapa seria imediata e não haveria solicitações que provocassem o deslizamento do NC, conseguindo promover o cisalhamento da ligação, mas não por mobilização do núcleo de concreto, como é o objetivo do estudo.

Quando há conectores de cisalhamento, esses dispositivos passam a ser mobilizados após a ruptura das parcelas de aderência, e o deslizamento do NC se inicia mais tarde. Quando os conectores são mobilizados e passam a trabalhar, o perfil de aço começa a ser solicitado, aparecendo deformações muito mais expressivas do que no modelo sem conectores. E, depois de um determinado tempo, o NC começa a deslizar e o processo de cisalhamento da ligação vai evoluindo até que ocorra a ruptura das barras rosqueadas.

Da análise dos resultados experimentais conclui-se que:

- Ruptura da ligação por cisalhamento;

- A ruptura não é simétrica, ou seja, ruptura das barras rosqueadas dos dois lados;

- Não houve deslocamento significativo do núcleo de concreto com relação ao perfil de aço;

- A presença de conectores de cisalhamento aumentam consideravelmente a transferência de esforços do núcleo de concreto para o perfil de aço, apesar de não ocorrer aumento da capacidade resistente à ruptura. 
- As cantoneiras comportam-se de forma mais eficiente que os conectores de cisalhamento tipo pino com cabeça (stud-bolts), não apenas na função finalidade de transferir os esforços de cisalhamento ao perfil de aço, mas também na restrição ao escorregamento do núcleo de concreto, sendo que a associação cantoneirasbarras rosqueadas mostrou-se muito positiva.

- As barras rosqueadas impedem consideravelmente o deslocamento do núcleo de concreto atuando como obstáculo físico ao deslizamento e, quando associado com conectores de cisalhamento, essa restrição ao escorregamento torna-se ainda mais significativa.

- Ocorre esmagamento do núcleo de concreto localizado antes das barras rosqueadas;

- Grande parte da força aplicada é absorvida pelo núcleo de concreto;

- Ocorre diminuição da deformação do núcleo de concreto, isto porque os esforços absorvidos pelo NC passam a ser transferidos para o perfil de aço, quando há conectores de cisalhamento;

- Os conectores de cisalhamento tipo cantoneira apresentam maior eficiência na transferência dos esforços de cisalhamento em todos os pontos ao longo do perfil, sendo mais expressivo na região da ligação.

- As deformações no lado direito do perfil de aço não são iguais àquelas do lado esquerdo, mas em todos os modelos, as deformações do lado direito são maiores que as do lado esquerdo. A explicação para tal fato pode ser: aplicação excêntrica do carregamento e/ou imperfeições geométricas do perfil e dos conectores.

- A instrumentação das barras rosqueadas não foi adequada, pois media somente as deformações axiais, que não são predominantes para a solicitação de cisalhamento a que as barras rosqueadas estão submetidas. 



\section{Análise Numérica}

A modelagem numérica tem por objetivo reproduzir, da melhor forma possível, os ensaios experimentais, cujos resultados servem para calibração dos modelos numéricos de interesse.

Com os avanços no campo computacional, a utilização de modelos numéricos em elementos finitos (MEF) torna-se uma grande ferramenta para estudar o comportamento das ligações viga-pilar misto preenchido, devido à grande complexidade do comportamento dessas ligações mistas, auxiliando no estudo dos fenômenos que influenciam este comportamento.

Para o desenvolvimento da análise numérica foi utilizado o método dos elementos finitos e o software DIANA 9.1®.

Utilizou-se de algumas variáveis na modelagem que foram:

- Presença e ausência de confinamento no núcleo de concreto;

- Local de aplicação do carregamento (seção mista - aço e concreto ou apenas no núcleo de concreto);

- Local da reação de apoio (chapa de ligação ou em um bloco de apoio para a chapa de ligação);

Neste capítulo são apresentadas informações pertinentes ao programa DIANA 9.1®, as dimensões geométricas do modelo, os tipos de elementos finitos adotados, as 
propriedades físicas dos materiais, a malha de elementos finitos, a discretização da geometria do modelo, as condições de contorno e de solicitação, resultados e conclusões.

É importante ressaltar que não foi possível colocar elemento de interface entre o núcleo de concreto e o perfil de aço. Foram feitas várias tentativas para inserir o elemento, entretanto eram encontradas algumas incompatibilidades no momento de gerar a malha de elementos finitos.

\subsection{O Pacote Computacional DIANA $9.1{ }^{\circledR}$}

O pacote computacional DIANA 9.1® é desenvolvido por um grupo de engenheiros civis da TNO Building and Construction Research Company, na Holanda desde 1972. Com base no método dos elementos finitos, método dos deslocamentos, é considerado uma ferramenta de análise numérica poderosa para análises tridimensionais e não lineares.

O programa possibilita também considerar alguns fenômenos complexos existentes em estruturas de concreto armado, como a fissuração, a plasticidade, a fluência, a cura, os efeitos de temperatura e a instabilidade. Além disso, o programa possui uma biblioteca ampla em que oferece ao usuário elementos de viga, elementos sólidos, elementos de membranas, de placas, de cascas, de contato e de interface.

O pacote computacional é composto por um pré-processador, identificado como iDIANA. Nele o usuário define a geometria do modelo, os carregamentos, as condições de contorno, as propriedades físicas e geométricas dos materiais, as divisões das linhas, os elementos finitos a serem utilizados e a geração da malha. As definições de unidades e do modo de trabalho (2D ou 3D) devem ser realizadas ao iniciar um novo arquivo. A Figura 4.1 apresenta a interface gráfica do iDIANA. 


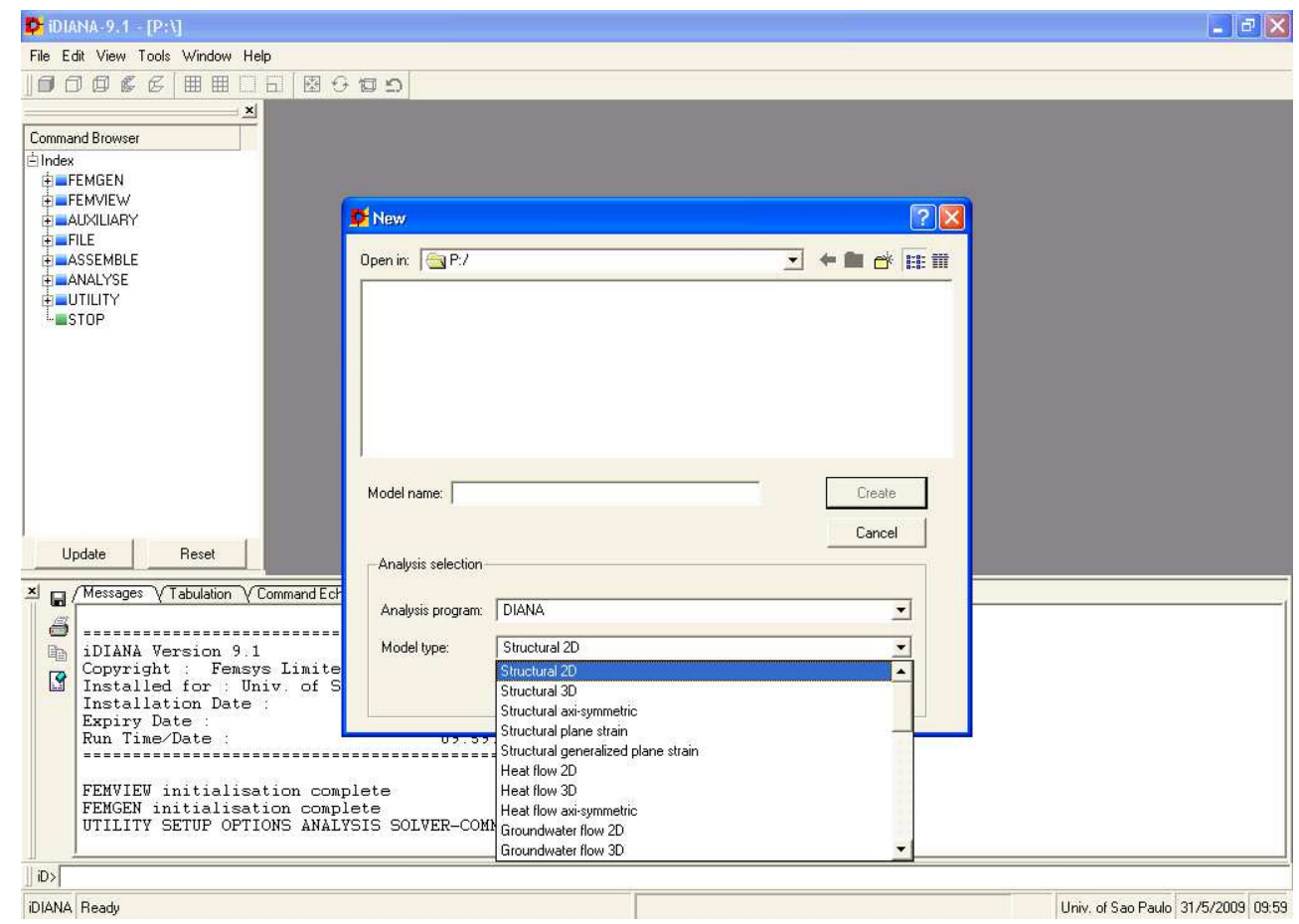

Figura 4.1. Interface gráfica do iDIANA.

O iDIANA permite o uso de scripts contendo todos os comandos necessários para a criação do modelo (APÊNDICE A - Dados de entrada). O uso de scripts é bastante comum entre usuários de programas de elementos finitos, uma vez que sua utilização acelera a criação do modelo, bem como permite alterações de modo rápido por meio de linhas de comando.

Terminada a fase de Pré-Processamento, o usuário cria um arquivo com todas as informações relativas ao modelo, para ser lido pelo processador, DIANA.

No DIANA o usuário fornece informações relativas ao tipo de análise a ser feita, que podem ser: estática, não-linear física e geométrica, análise modal, análise transiente, entre outras. A Figura 4.2 apresenta a interface do processador DIANA. 


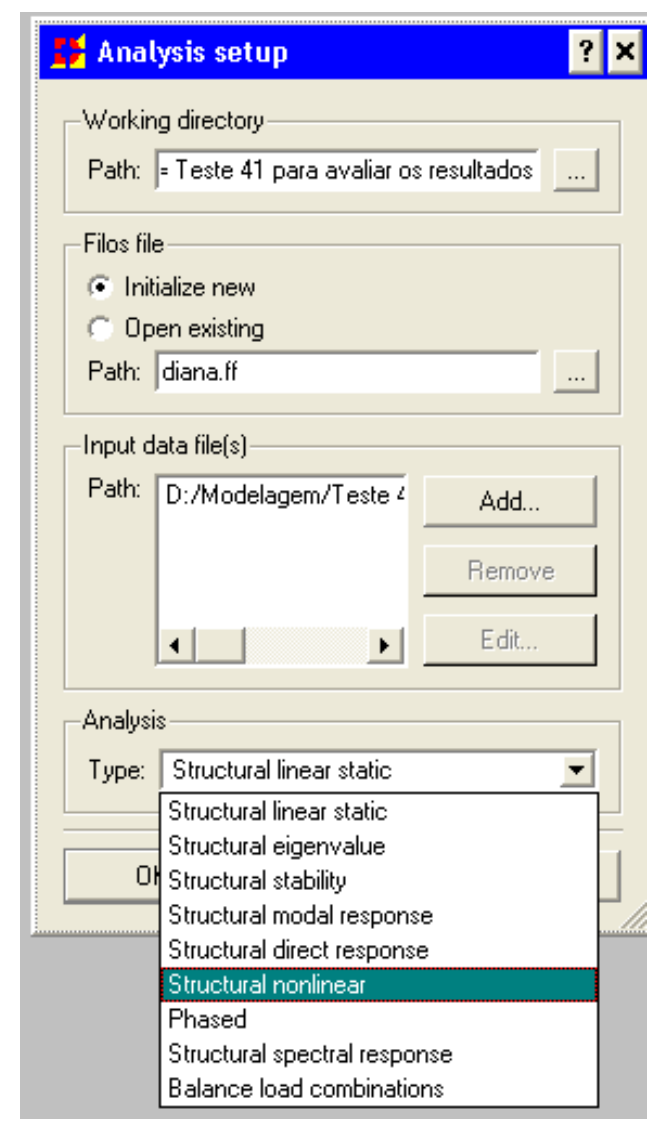

Figura 4.2. Interface gráfico do DIANA

\subsection{Critérios Gerais Adotados no Modelo Numérico Estudado}

Para simplificar o processamento, ou seja, diminuir o custo computacional e o tempo de processamento, para todos os modelos utilizou-se um plano de simetria. Dessa forma apenas uma metade do modelo foi modelada e analisada. Inicialmente foram utilizados dois planos de simetria, modelando apenas um quarto do modelo. Entretanto os resultados obtidos não foram ideais, e acreditava-se que modelar meio modelo melhoraria os resultados. Quando foi modelado metade do modelo, descobriu-se que o problema que estava dando na modelagem de um quarto não tinha nada a ver com o tamanho do modelo, mas como já estava pronta a geometria do meio modelo, continuou a análise por ele. O modelo numérico estudado é ilustrado na Figura 4.3. 


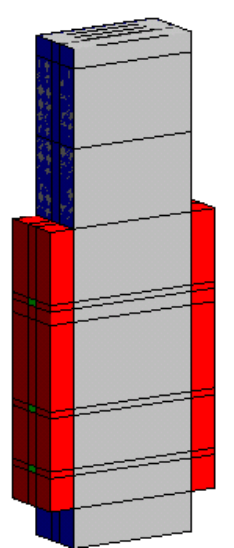

Total

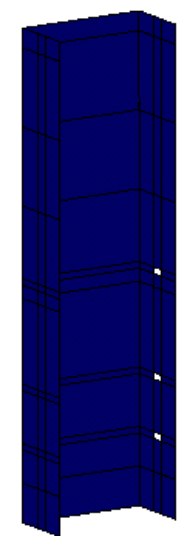

Pilar de Aço

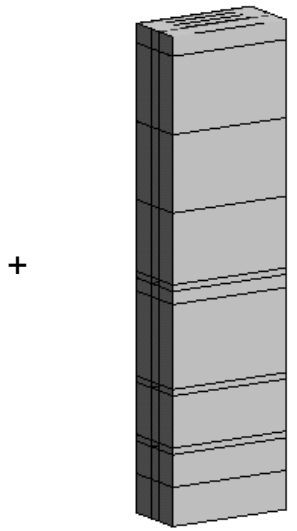

Núcleo de concreto

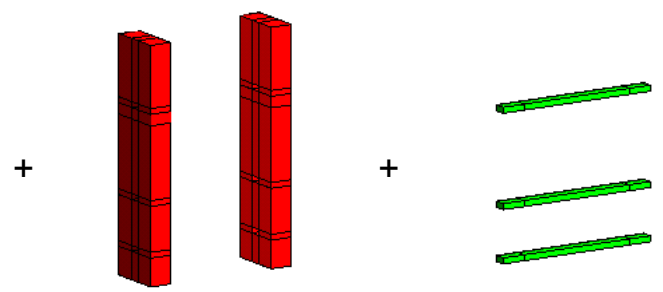

Chapa de Barras Ligação

Figura 4.3. Modelos numéricos

A elaboração do modelo numérico estudado consistiu basicamente das seguintes etapas enumeradas a seguir e que são apresentadas em forma de um fluxograma no APÊNDICE A. É importante ressaltar que cada etapa depende do sucesso da etapa anterior.

\subsubsection{Definição da geometria}

A geometria do modelo estudado foi realizada através da criação de pontos por meio de suas coordenadas. Em seguida criou-se as linhas pela combinação de pontos, de forma a se tornar possível a definição do número de divisões das mesmas para a geração da malha, pois não se queria trabalhar com a divisão "default" do DIANA 9.1®. Como os elementos utilizados são de aproximação cúbica, foi necessário usar divisões pares para as linhas. Dessa forma algumas linhas receberam divisões 2, 4, 6, 8, 10 e 12, dependendo da necessidade de refinamento da região. 
Com a criação dos pontos, criou-se também as superfícies. Com as superfícies definiu-se os body's, que foram criados por meio de superfícies paralelas.

De modo a facilitar a definição das propriedades dos materiais e a exportação de dados, criou-se os SET's, que podem ser definidos como grupos. Na modelagem foram criados SET's por tipo de objeto (concreto, aço, barra rosqueada, chapa de ligação, reação de apoio e carga) e por pontos de exportação de resultados, que representavam os pontos onde tinham sido instrumentados o concreto, o perfil de aço e o barra rosqueada na análise experimental.

\subsubsection{Definição dos elementos finitos}

Para a modelagem do núcleo de concreto, das barras rosqueadas, da chapa de ligação, do elemento de reação e do elemento de aplicação do carregamento foram utilizados elementos sólidos. Já para o perfil de aço utilizou-se um elemento de casca.

Os elementos sólidos na maioria das vezes apresentam um custo computacional alto devido ao tamanho da matriz de rigidez e por necessitar de um bom refinamento da malha de forma a obter soluções mais próximas do adequado, devendo ser utilizados apenas onde não é possível utilizar elementos menos robustos.

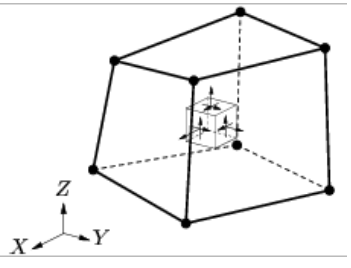

Figura 4.4. Elemento sólido. (DIANA 9.1)

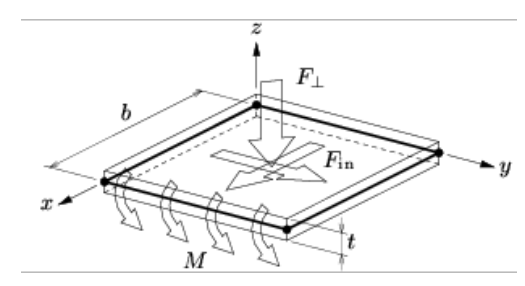

Figura 4.5. Elemento de casca - Flat Shell. (DIANA 9.1)

Inicialmente, optou-se por utilizar elementos finitos com aproximação linear para os deslocamentos. Entretanto, verificou-se nos manuais do DIANA $9.1 \AA^{\circledR}$ que em análises não 
linear, não se recomenda a utilização de elementos com função aproximadora linear. Por esse motivo, optou-se por utilizar elementos com aproximação cúbica. A Tabela 4.1 apresenta os elementos finitos usados.

Tabela 4.1. Elementos finitos adotados na modelagem

\begin{tabular}{lll}
\hline Tipo de Elemento & Tipo Elemento & Elemento Finito \\
& (DIANA 9.1®)
\end{tabular}

\begin{tabular}{cccc}
\hline Núcleo de Concreto & Sólido & HE20 & CHX60 \\
Perfil de Aço & Casca- Flat Shell & QU8 & CQ40F \\
Barras rosqueadas & Sólido & HE20 & CHX60 \\
Chapa de Aço & Sólido & HE20 & CHX60 \\
Reação de Apoio & Sólido & HE20 & CHX60 \\
Elemento de aplicação do & Sólido & HE20 & CHX60 \\
carregamento & & & \\
\hline
\end{tabular}

O elemento finito $\mathrm{CHX60}$ é um elemento isoparamétrico com 20 nós, e função aproximadora quadrática para os deslocamentos. A Figura 4.5 apresenta o elemento $\mathrm{CHX60.}$

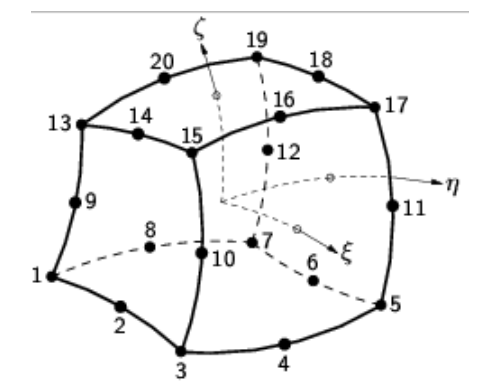

Figura 4.6. Elemento $\mathrm{CHX60.}$

O elemento finito CQ40F é um elemento isoparamétrico, quadrilateral com 8 nós, e função aproximadora para os deslocamentos e é apresentado na Figura 4.7 


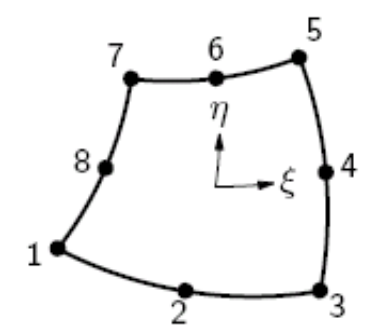

Figura 4.7. Elemento CQ40F.

\subsubsection{Definição das propriedades dos materiais}

O pacote computacional DIANA $9.1{ }^{\circledR}$ dá a possibilidade de se adotar propriedades geométricas e físicas, lineares e não-lineares aos materiais.

\section{A. Concreto}

Em estruturas de concreto sabe-se que atingida certa intensidade de solicitação, ocorre uma redução da capacidade resistente com acréscimo significativo de deformação. Esse comportamento global existe em virtude de um efeito que ocorre no material, conhecido como "strain softening", também conhecido como amolecimento, e ocorre tanto no comportamneto à tração como na compressão.

Devido a esse efeito de amolecimento, as deformações tendem a se apresentar de maneira mais acentuada em certas regiões da estrutura, de modo que a discretização da malha de elementos finitos nessas regiões passa a ser importante na qualidade dos resultados. Uma discretização mais refinada nessa regiões aumenta, na maioria das vezes, o custo computacional da análise em questão. No DIANA $9.1 \AA^{\circledR}$, um meio de superar essa dificuldade é fazer uso de critérios da Mecânica da Fratura e da Mecânica do Dano. 
O DIANA $9.1{ }^{\circledR}$ apresenta dois modelos de fissuração, que simulam o efeito de fraturamento nas estruturas de concreto: modelo de fissuração discreta ("discrete crack model") e o modelo de fissuração distribuída ("smeared crack model").

Na modelagem realizada, optou-se pelo modelo de fissuração distribuída, em que os parâmetros da mecânica da fratura necessários para sua representação são: energia de fraturamento na tração e na compressão ( $G f$ e $G c)$, resistência à tração e à compressão, coeficiente de retenção ao cisalhamento $\beta$, e comprimento de banda de fissuras ("crack band"). Feenstra \& Borst (1993) apud Barros (2009), indicam que em ensaios experimentais, a energia de fraturamento na compressão, Gc, apresenta valores entre 50 e 100 vezes superiores à energia de fraturamento na tração, Gf.

A energia de fraturamento, tanto na tração como na compressão, pode ser entendida como a energia necessária para causar um dano irreverssível no material. Para se obter o valor do parâmetro Gf é necessário realizar um ensaio de deformação controlada e medir a área do diagrama tensão versus abertura de fissuras, como mostra a figura 4.8.

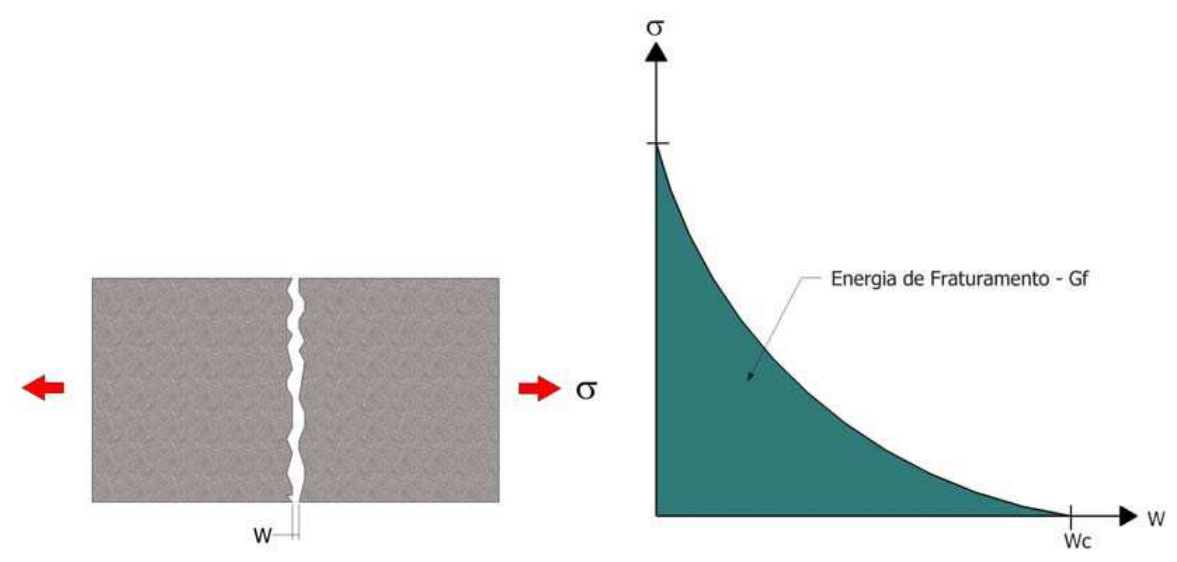

Figura 4.8. Energia de fraturamento na tração, Farias (2008)

A energia de fraturamento pode ser ainda definida como um parâmetro que depende da resistência à compressão e do tamanho máximo do agregado (Dmáx). O CEBFIP Model Code (1990) permite calcular o valor de Gf por meio das expressões 4.1 e 4.2: 


$$
\begin{gathered}
G_{f}=G_{F 0}\left(f_{c m} / f_{c m o}\right)^{0,7} \\
f_{c m}=f_{c k}+8
\end{gathered}
$$

Em que:

- G é a energia de fraturamento na tração, dada em N.mm/mm²;

- $f_{c m o}$ vale $10 \mathrm{~N} / \mathrm{mm}^{2}$;

- $f_{c k}$ é a resistência característica à compressão do concreto, em N/mm²;

- Gło é um parâmetro que depende do tamanho máximo do agregado, conforme apresentado na tabela 4.3.

Tabela 4.2. Valores de Głoem função de Dmáx

\begin{tabular}{cc}
\hline $\mathbf{G}_{\text {fo }}\left(\mathrm{N} \mathbf{m m} / \mathrm{mm}^{2}\right)$ & $\mathbf{D}_{\text {máx }}(\mathbf{m m})$ \\
\hline 0,025 & 8 \\
0,030 & 16 \\
0,058 & 32 \\
\hline
\end{tabular}

O coeficiente de retenção ao cisalhamento, $\beta$ é um parâmetro que permite reduzir o valor do módulo de elasticidade transversal do material, após iniciada a fissuração, sendo que essa redução pode se dar de maneira completa, constante ou variável. De acordo com Farias (2008) apud Barros (2009), a influência desse parâmetro é maior em problemas cuja ruptura ocorra por cisalhamento

Por fim, o comprimento de banda de fissuras é utilizado para suprir a dependência de malha do modelo. Esse parâmetro pode ser fornecido pelo usuário, bem como calculado pelo programa, em função do tipo de elemento finito utilizado. As expressões 4.3, 4.4 e 4.5 mostram como o comprimento de banda de fissura é calculado no DIANA 9.1® 
para elementos bidimensionais de ordem linear, bidimensionais de ordem quadrática e elementos tridimensionais, respectivamente.

$$
\begin{gathered}
h=\sqrt{A_{e}} \\
h=\sqrt{2 \cdot A_{e}} \\
h=\sqrt[3]{V_{e}}
\end{gathered}
$$

Em que:

- Ae é a área do elemento finito adotado;

- $V_{e} \quad$ é o volume do elemento finito adotado;

- h comprimento de banda de fissuras.

Com base nos valores de $G_{f}$ e de $h$, calcula-se gf, que é o trabalho inelástico do material. Esse parâmetro representa a quantidade de energia necessária a ser dissipada em um elemento da malha de elementos finitos, para que ocorra um dano irreversível no material.

O pacote computacional DIANA 9.1 ${ }^{\circledR}$ trata a abertura e a orientação das fissuras por meio de dois modelos disponíveis no programa: Modelos Incrementais ou Plásticos e Modelos Total Strain.

Os modelos Total Strain descrevem o comportamento do material na tração e na compressão baseados apenas numa relação tensão-deformação. De acordo com DIANA $9.1 \circledast(2005)$, esses modelos representam de maneira satisfatória os estado limites último e de serviço de estruturas de concreto armado.

Os modelos total strain podem ser ainda do tipo: Rotating Crack Model e Fixed Crack Model. O Rotating Crack Model permite que a abertura da fissura mude de direção 
enquanto a mesma se propaga no material, e o Fixed Crack Model mantêm o mesmo ângulo da abertura da primeira fissura, permitindo que a mesma mude de direção apenas nos casos em que a variação do ângulo da fissura seja igual a $90^{\circ} \mathrm{em}$ relação ao inicial.

Nos Modelos Total Strain a entrada de dados compreendem duas partes: na primeira são definidos parâmetros básicos como o módulo de elasticidade longitudinal do material, coeficiente de Poisson e resistência à tração e à compressão. Já na segunda etapa, são definidos o comportamento do material na tração, na compressão e no cisalhamento, através de leis constitutivas. As leis constitutivas disponíveis no pacote computacional DIANA $9.1 \AA^{\circledR}$ para o comportamento dos materiais tanto à tração como à compressão são baseadas na energia de fraturamento, anteriormente detalhada, e podem ser vistas nas figuras 4.5 e 4.6 .

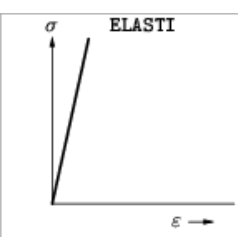

(a) elastic

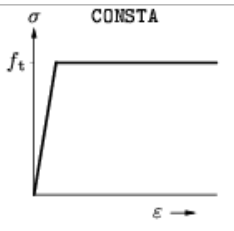

(b) ideal

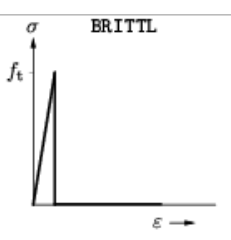

(c) brittle

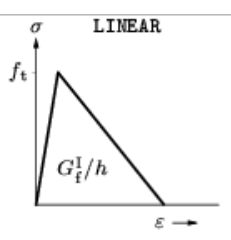

(d) linear

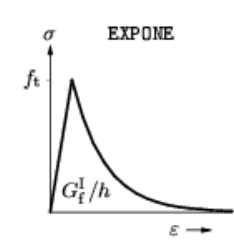

(e) exponential

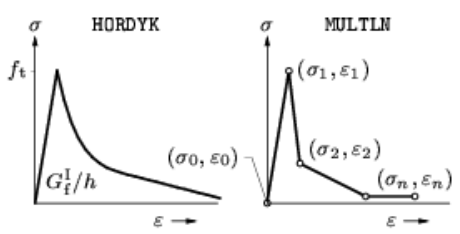

(f) Hordijk (g) multi-linear

Figura 4.9. Modelos Constitutivos à tração pré-definidos, disponíveis em DIANA 9.1® (2005b) 


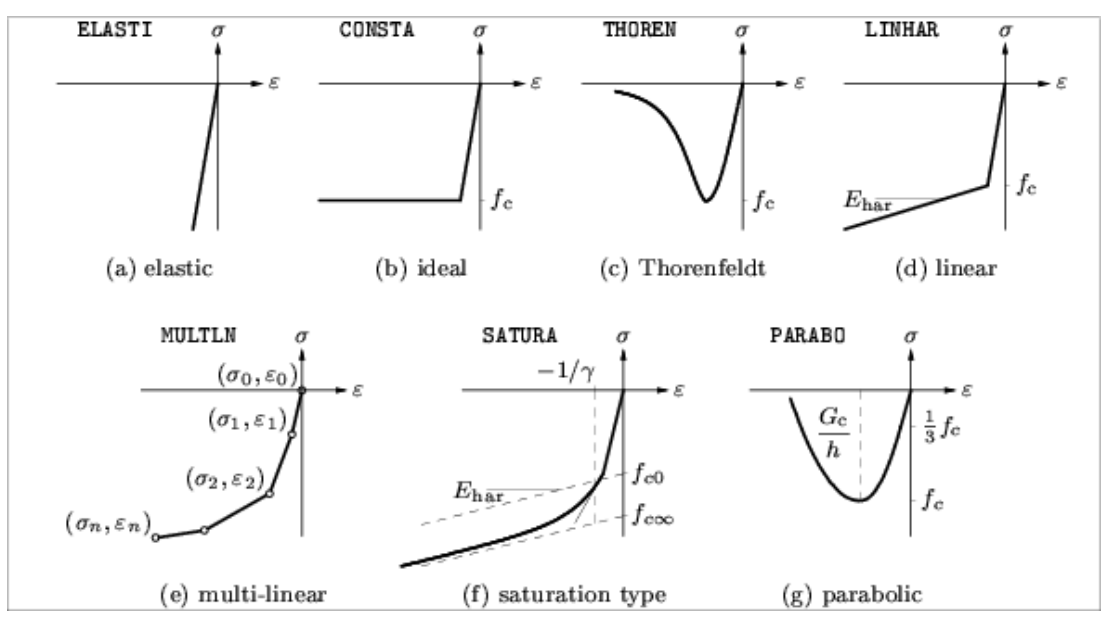

Figura 4.10. Modelos Constitutivos à compressão pré-definidos, disponíveis em DIANA 9.1® (2005b)

Devido ao efeito da fissuração pode ocorrer uma redução do módulo de elasticidade transversal do material. Essa redução é considerada por meio do coeficiente de retenção ao cisalhamento, $\beta$, que no pacote computacional DIANA 9.1® é representado por três modos: retenção completa, retenção constante e retenção variável.

Na situação de retenção completa, o módulo de elasticidade transversal não sofre redução alguma. No modo de retenção constante, o usuário define um valor para o parâmetro $\beta$, que deve estar no intervalo entre 0 e 1. Em problemas onde o cisalhamento é importante no modo de ruptura da estrutura, o valor de $\beta$ deve ser tomado próximo à zero, quando não, próximo à unidade. Por fim, no modo de retenção variável o parâmetro $\beta$ é calculado como uma função da deformação das fissuras.

Ainda podem ser considerados nos Modelos Total Strain o efeito lateral por conta da fissuração e do confinamento do material. Entretanto, não podem ser combinados quando do uso do diagrama multi-linear para o comportamento do material à compressão.

Para utilizar esses efeitos de fissuração lateral e confinamento do material, o pacote computacional DIANA 9.1® disponibiliza duas funções, REDCRV e CNFCRV, que devem ser ativadas via arquivo do tipo .DAT antes do processamento, não podendo ser ativado de forma visual via pré-processador. Para tanto, para ativar a função REDCRV é preciso utilizar 
o comando VC1993 na guia referente às propriedades dos materiais, assim como para ativar a função CNFCRV, deve-se utilizar o comando VECCHI.

A função REDCRV permite que no concreto fissurado, grandes deformações ocasionadas por tração perpendicular às direções principais de compressão, reduzam a resistência à compressão do material. O modelo adotado no DIANA 9.1® é o proposto por Vecchio e Collins em 1993. A figura 4.7 mostra como o DIANA 9.1® considera essa redução. Já o aumento da resistência à compressão do material é considerado em virtude do confinamento lateral, por meio da função CNFCRV.

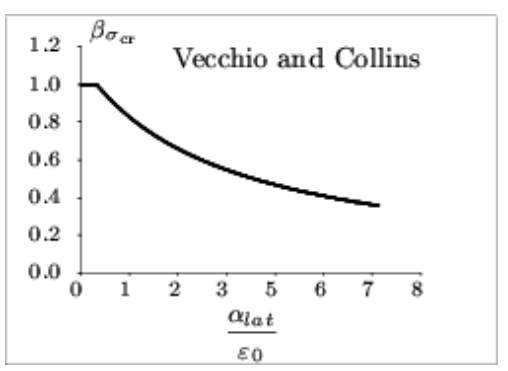

Figura 4.11. Fator de redução devido a fissuração lateral (Vecchio \& Collins, 1993).

Na modelagem realizada consideraram-se apenas os efeitos de confinamento do material.

Para o concreto foram adotadas propriedades geométricas lineares e não- lineares:

- LINEAR: elástico, isotrópico, módulo de elasticidade (E) de 35.100 MPa e coeficiente de Poisson $v=0,2$.

- NÃO-LINEAR: concrete and brittle materials, total strain rotating crack, direct input, exponente softening in tension e parabolic diagram. A Figura 4.8 apresenta a interface de propriedades do iDiana, com os valores adotados para cada parâmetro de tensão, energia de fratura. 


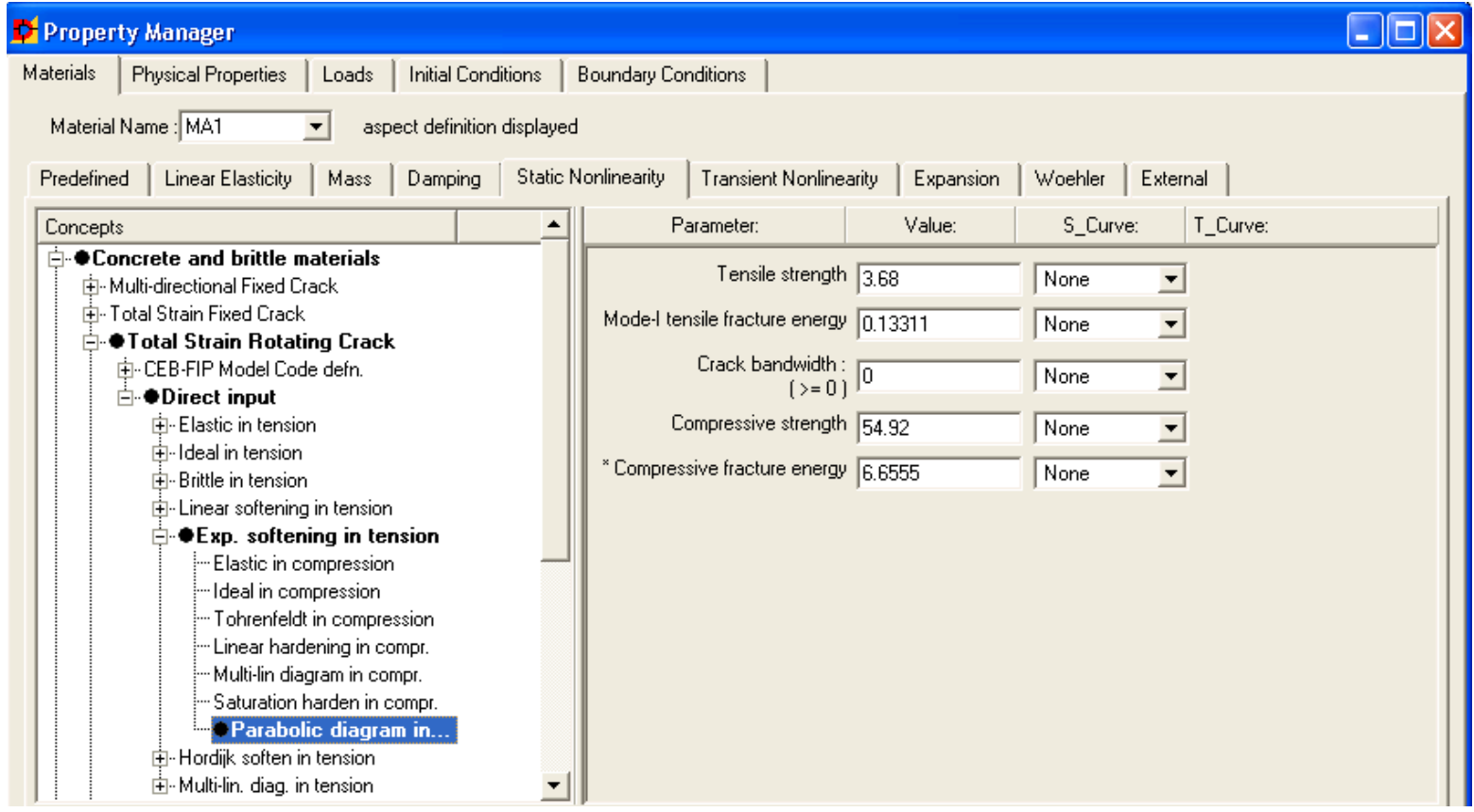

Figura 4.12. Propriedades não-lineares do concreto.

\section{B. Perfil de aço}

Para o perfil de aço, além das propriedades geométricas lineares e não lineares, utilizou-se também propriedade física.

As propriedades geométricas adotadas foram:

- LINEAR: elástico, isotrópico, módulo de elasticidade de 205000 MPa e coeficiente de Poisson $v=0,3$.

- NÃO-LINEAR: metals, Von Misses, tensão de escoamento (fy) igual a 242,2 N.

A propriedade física adota foi a de casca do tipo Flat Shell de espessura 6,3 mm.

A Figura 4.13 apresenta a interface do iDiana com as propriedades geométricas lineares do perfil de aço e a Figura 4.14 as propriedades geométricas não-lineares e a Figura 4.15 a propriedade física. 


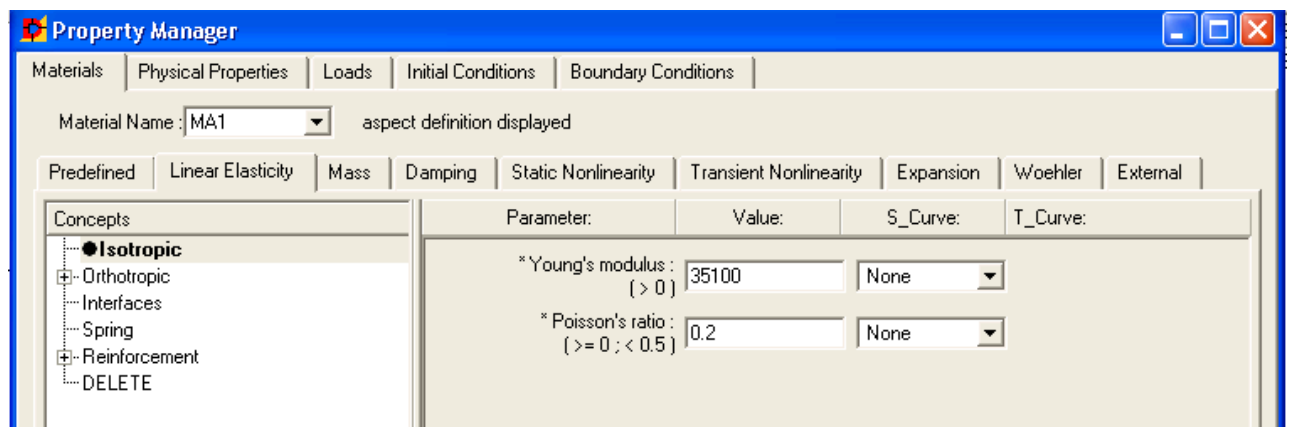

Figura 4.13. Interface iDiana, propriedades geométricas lineares.

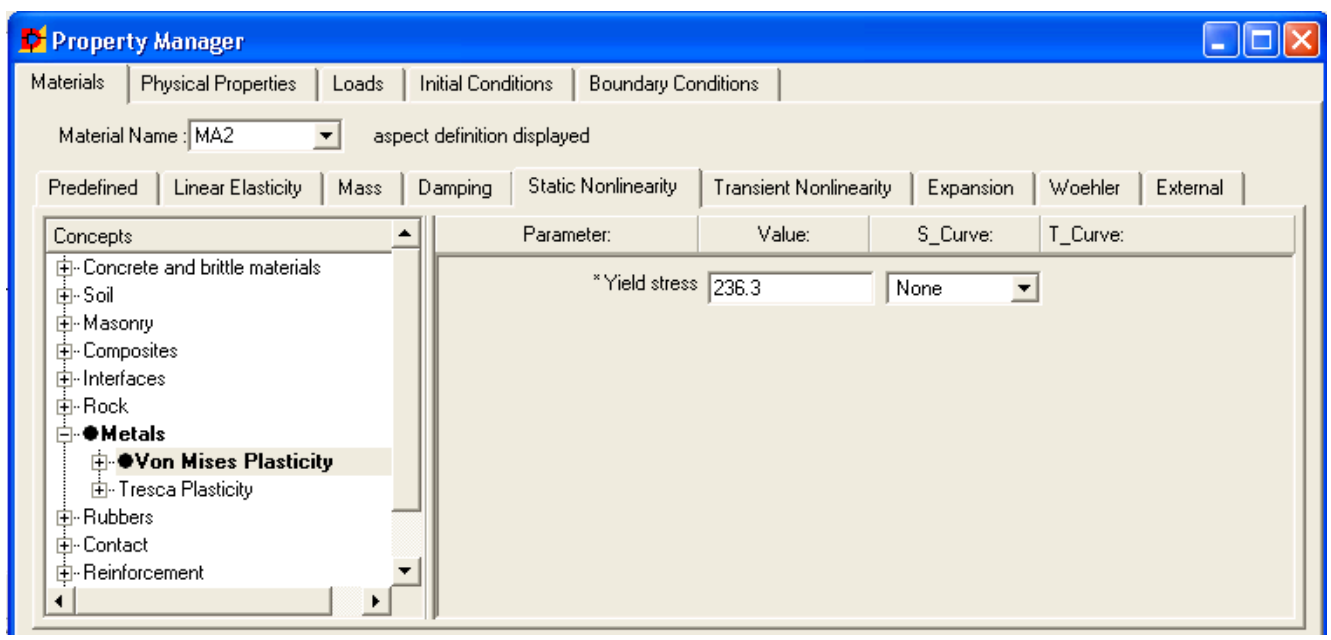

Figura 4.14. Interface iDiana, propriedades geométricas não - lineares.

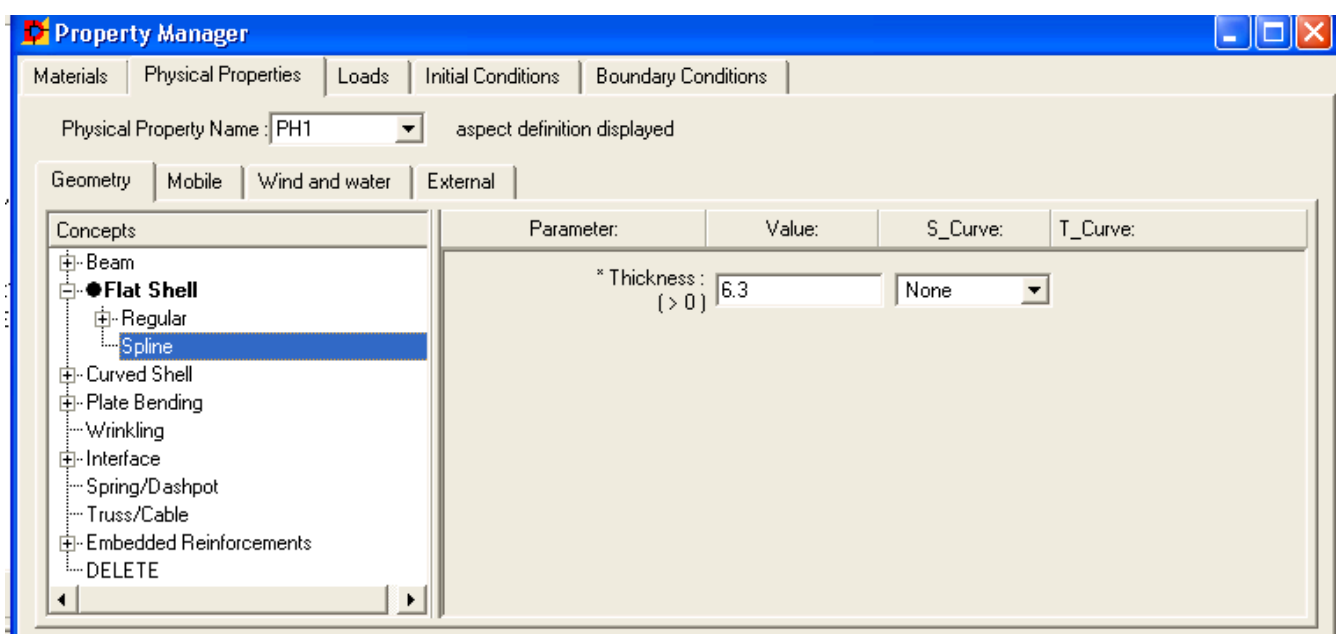

Figura 4.15. Interface iDiana, propriedade física. 


\section{Barras Rosqueadas}

Para as barras rosqueadas foram adotadas propriedades geométricas lineares e não lineares.

- LINEAR: elástico, isotrópico, módulo de elasticidade de 205000 MPa e coeficiente de Poisson $v=0,3$.

- NÃO-LINEAR: metals, Von misses, tensão de escoamento (fy) igual a 743,92 N.

Para a chapa de ligação e para o corpo em que foi aplicado o carregamento foi adotada propriedade geométrica linear elástico e isotrópico com módulo de elasticidade bem elevado, de forma que eles não sofressem qualquer deformação. Desse modo usou o valor máximo permitido pelo iDiana de 1.000.000.000 MPa e coeficiente de Poisson igual a 0,01

\subsubsection{Definição das condições de contorno e de carregamento}

Foram adotadas dois tipo de condições de contorno na modelagem. A primeira diz respeito às restrições de translação e rotação e a segunda às condições de simetria.

Foram restringidos movimentos de translação em $X, Y$ e rotação em $X, Y$ e $Z$ no elemento em que se aplicou o carregamento. E no elemento que servia de reação de apoio foi restringido o movimento de translação em z.

Como foi modelado apenas metade do real, usou-se condição de simetria com relação ao eixo y, de forma a representar o modelo como um todo.

O carregamento foi aplicado apenas no núcleo de concreto, desse modo criou-se pontos para o núcleo de concreto de forma que não coincidisse com o perfil de aço para que ficasse claro e tivesse a certeza de que o carregamento não seria aplicado de forma alguma ao perfil de aço. Entretanto, foi realizado um teste em que se aplicou o 
carregamento na seção mista, desse modo provocou no momento da criação do modelo a coincidência dos pontos que são comuns ao aço e ao concreto.

\subsubsection{Escolha dos parâmetros para efetuar o processamento}

Os parâmetros a serem escolhidos no DIANA para realização do processamento são:

- Método de resolução do sistema de equações não-lineares;

- Número de passos de carga (incrementos);

- Número máximo de iterações;

- Critério de convergência;

- Tamanho máximo do passo de carga;

- Critério de convergência

O DIANA 9.1® dispõe de diversos métodos que podem ser aplicados como estratégia na resolução dos sistemas de equações não-lineares: método de Newton-Raphson Regular, Newton-Raphson Modificado, Método Secante e Método da Rigidez Linear.

A estratégia de Newton-Raphson é incremental-iterativa, na qual supõe que o resíduo gerado entre duas iterações consecutivas possa ser considerado contínuo na vizinhança da solução. Assim, supõe-se que numa dada iteração $r$ o resíduo em relação à iteração r-1 seja nulo e, portanto, possa ser escrito em termos de série de Taylor. Tomando-se a hipótese de que a "função resíduo" tenha uma variação suave, é possível admiti-la até o termo de primeira ordem da série de Taylor. Nota-se que essa condição considera que a força aplicada na estrutura não varia com os deslocamentos, o que é condizente com a condição de forças conservativas. Além do uso de iterações, é comum em uma análise não-linear dividir o carregamento em vários passos de carga, de modo que para cada um são realizadas várias iterações até que haja convergência do problema, caracterizando, portanto, uma estratégia incremental-iterativa. 
A estratégia incremental-iterativa de Newton-Raphson busca calcular um incremento nos deslocamentos em cada passo de carga. Para tanto, a cada iteração é preciso atualizar a matriz de rigidez, sendo nesse caso denominada matriz de rigidez tangente. A utilização da matriz tangente em cada iteração é o que caracteriza o método de NewtonRaphson Regular. Esse método consome grande esforço computacional, porém apresenta convergência com poucas iterações.

Já na estratégia incremental-iterativa de Newton-Raphson Modificado, a matriz de rigidez tangente é calculada apenas na primeira iteração de cada incremento de carga, e mantida constante nas iterações seguintes. Assim, nos demais passos a matriz de rigidez utilizada passa a ser uma matriz secante. Esse processo demanda um número maior de iterações, e por isso, costuma convergir mais lentamente que o método de Newton-Raphson regular.

O método secante, por sua vez, não necessita da atualização da matriz de rigidez em cada iteração, utilizando também uma matriz de rigidez tangente. Entretanto, baseia-se na solução prévia dos vetores de forças não balanceados, para obter uma melhor aproximação durante a aplicação dos incrementos de carga. A utilização do método secante é recomendada quando as estratégias de Newton-Raphson não apresentarem boas soluções. Por fim, o método da rigidez linear é recomendado apenas quando nenhum dos métodos anteriores apresentarem boas soluções.

É comum a ocorrência de problemas que podem dificultar a convergência de durante a resolução de sistemas de equações não-lineares. Para isso o DIANA 9.1® dispõe de alguns recursos, como o critério de procura de linhas ("line search") e o critério de comprimento de arco ("arc length control"), que ajudam a contornar o problema de convergência.

O critério de line search busca um multiplicador ótimo para os incrementos de deslocamentos, de modo a acelerar a convergência das soluções. 
Já o critério de comprimento de arco é muito útil na busca do comportamento póspico das estruturas.

Quanto à aplicação do carregamento, optou-se por aplicar deslocamentos a um "body" com alta rigidez, de forma que esse transferisse o carregamento ao núcleo de concreto de maneira uniforme e sem se deformar. Foram aplicados passos de carga prédefinidos de 0,04 mm, com um tamanho de passo de 100. Limitou-se também o número de iterações a 100, uma vez que foram obtidos bons resultados.

O DIANA dispõe de quatro critérios de convergência baseados em normas de força, deslocamento, energia e resíduos. Todos esses comparados com um valor máximo de erro fornecido pelo usuário. O pacote computacional permite a combinação de dois critérios.

Na modelagem deste trabalho optou-se por usar o critério de convergência baseado em norma de energia. Esse critério é baseado no trabalho das forças internas presentes na estrutura, conforme a equação 4.6., e não forças externas. De acordo com DIANA $9.1 \circledR(2005, b)$, o uso de forças externas poderia conduzir a resultados incoerentes, quando do uso do critério de line search.

$$
E=\left|\frac{\delta u_{i}^{\top} \cdot\left(f_{i n t, i+1}+f_{i n t, i}\right)}{\Delta u_{0}^{\top} \cdot\left(f_{i n t, l}+f_{i n t, 0}\right)}\right|
$$

Segundo Souza (2006), o critério de convergência baseado em energia é mais interessante, pois considera simultaneamente o efeito das forças e dos deslocamentos. $\bigcirc$ autor conseguiu bons resultados em suas análises adotando tolerância de 10-2 em termos energéticos.

A Figura 4.16 mostra a interface gráfica do DIANA em que são determinados os parâmetros discutidos neste item. 


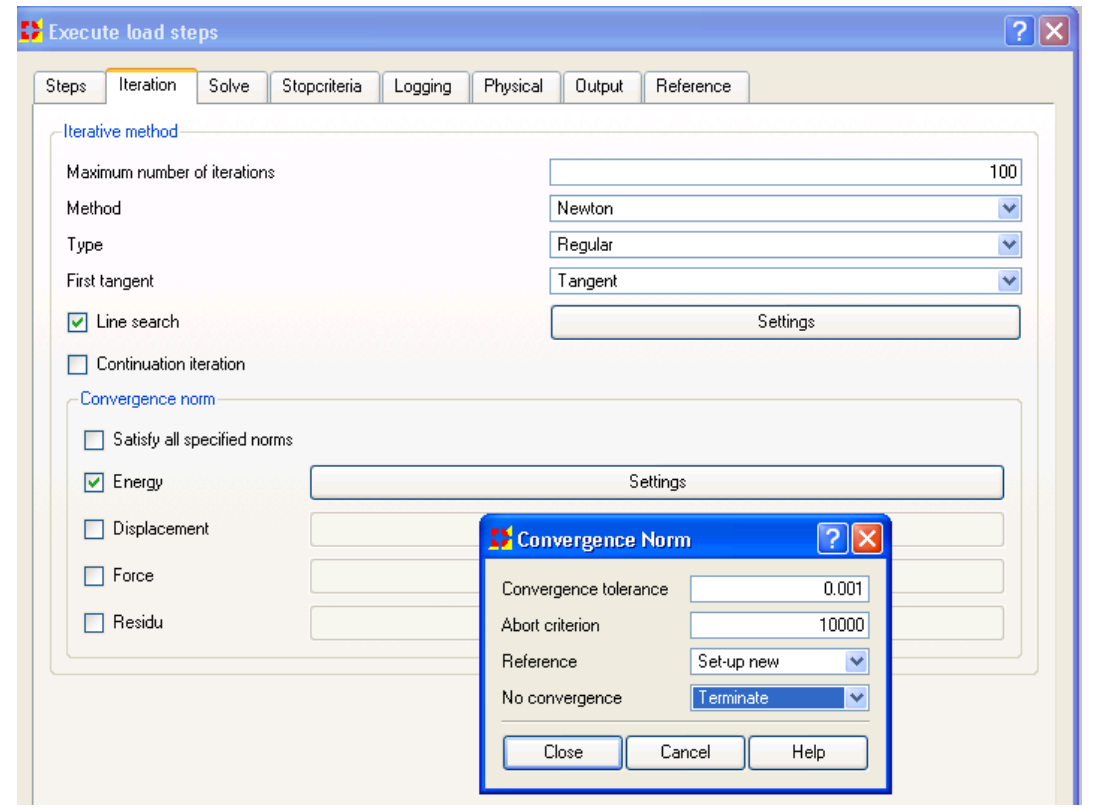

Figura 4.16. Interface gráfica - escolha método convergência, passos e iterações.

\subsubsection{Saída de resultados}

A saída de dados do programa pode ser feita por meio de arquivos tabulados, ou arquivos do tipo femview.

Os arquivos tabulados são de grande utilidade, uma vez que com eles pode-se solicitar apenas dados específicos, como por exemplo, o deslocamento ou a tensão em determinados pontos da estrutura. Para tanto, é preciso que o usuário defina um SET, que nada mais é do que um agrupamento de entidades geométricas, podendo ser composta de pontos, linhas ou bodys. Os resultados de modo tabulado só podem ser fornecidos em relação a determinados SETs. Já os resultados em modo femview, por sua vez, podem ser visualizados no iDIANA. É nesse tipo de arquivo que pode-se obter imagens dos panoramas de fissuração, distribuição de tensões e deformações, campos de deslocamentos, entre outros.

Na modelagem realizada foram extraídos os seguintes resultados:

- Núcleo de concreto: deslocamento, deformação; 
- Perfil de aço: deformação;

- Barras rosqueadas: deslocamento, deformação;

- Força aplicada.

- Deslocamento do núcleo de concreto;

- Deformação do núcleo de concreto;

\subsection{Testes realizados}

São apresentados neste trabalho cinco testes, em que os parâmetros de variação foram: local de aplicação do carregamento, local da reação de apoio e presença e ausência de confinamento, identificados no fluxograma da figura 4.17.

Local de aplicação do carregamento

\section{Local de aplicação}

reação

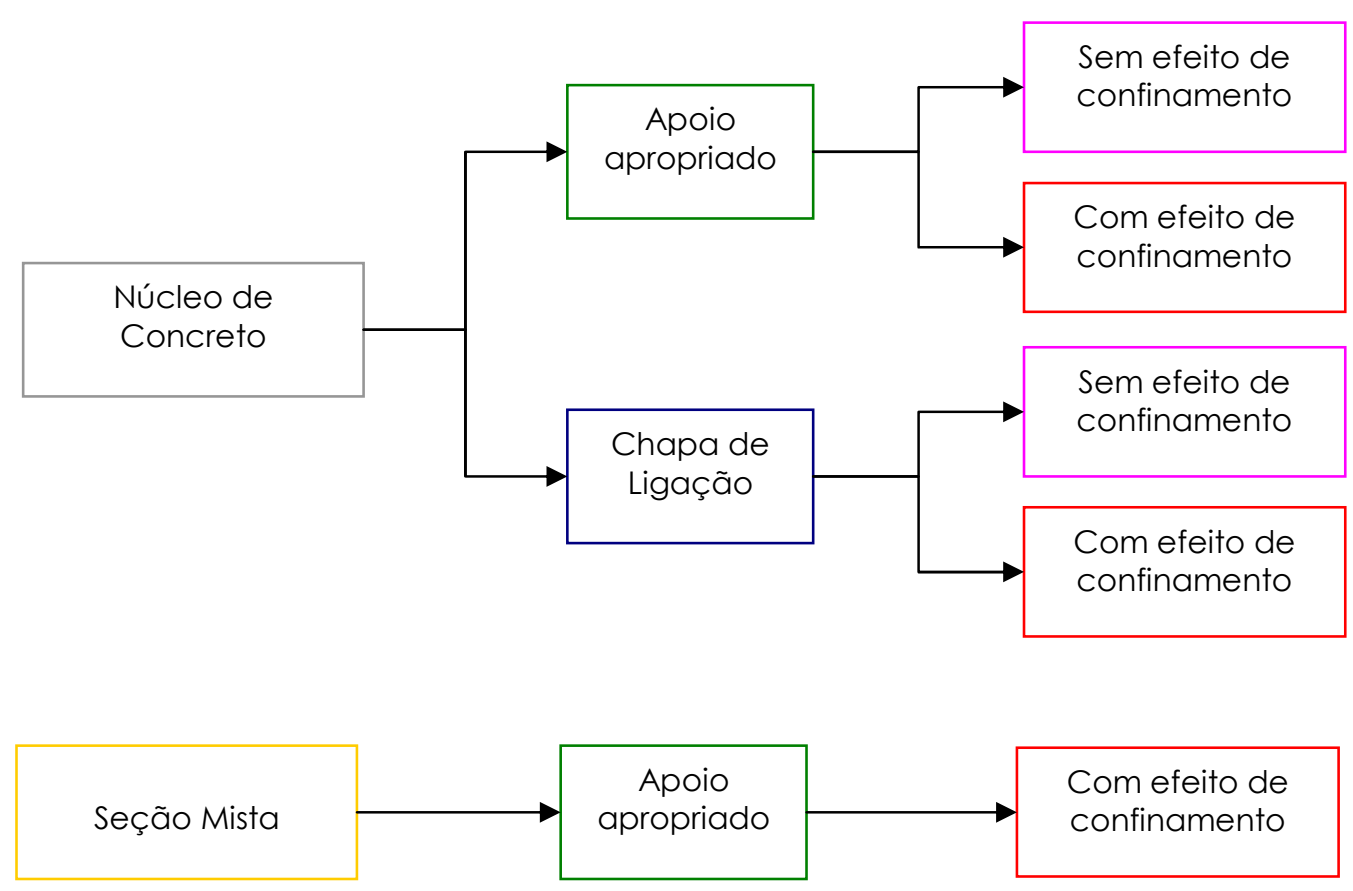

TESTE a

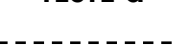

TESTE b

TESTE C

TESTE d

TESTE e

Figura 4.17. Fluxograma de testes realizados 


\subsection{Resultados}

A análise dos resultados será feita de forma comparativa entre os testes realizados. Desse modo foram feitos 3 estudos comparativos dos resultados numéricos, procurando analisar por meio de gráficos do tipo:

- Força aplicada versus Deformação do núcleo de concreto;

- Força aplicada versus Deslocamento do núcleo de concreto.

As comparações realizadas foram entre os seguintes testes:

- Comparação 01: Teste a X Teste b - observar a questão do efeito de confinamento; (Fluxograma representado pela Figura 4.18)

- Comparação 02: Teste b X Teste d - observar a questão da forma como é definido o apoio: a chapa de ligação como apoio e um apoio próprio em que a chapa de ligação é apoiada (Fluxograma representado pela Figura 4.19);

- Comparação 03: Teste b X Teste e - observar a mudança na forma de aplicação do carregamento: na seção mista e apenas no núcleo de concreto (Fluxograma representado pela Figura 4.20).

As demais comparações que poderiam ser feitas entre os testes realizados não serão feitas, haja vista que os resultados são semelhantes. 
Comparação 01

TESTE $a \times$ TESTE $b$

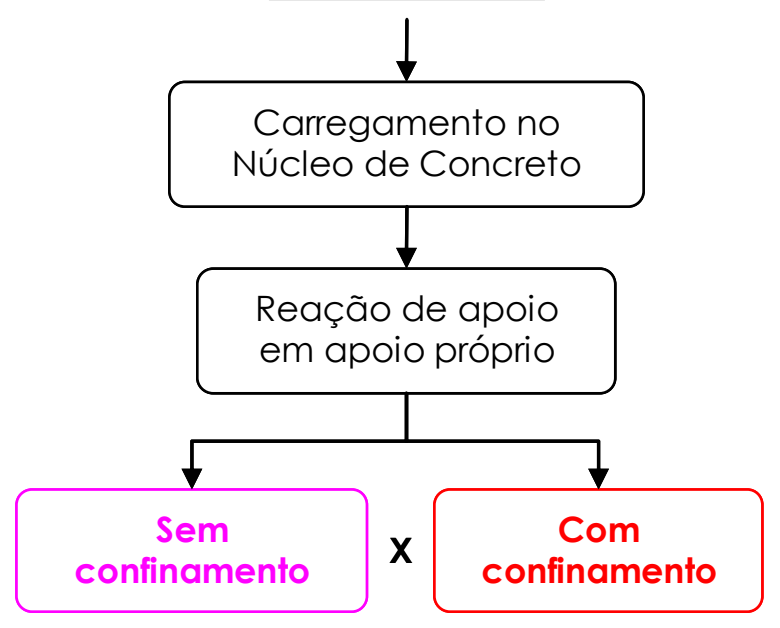

Figura 4.18. Fluxograma representativo da comparação 01.

\section{Comparação 02}

TESTE $b$ X TESTE $d$

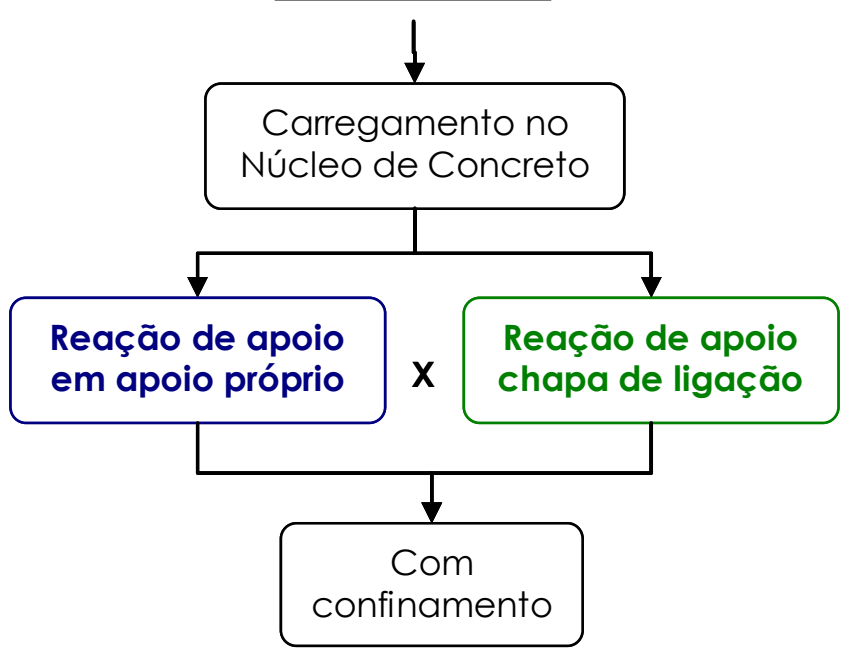

Figura 4.19. Fluxograma representativo da comparação 02.

\section{Comparação 03}

TESTE b X TESTE e

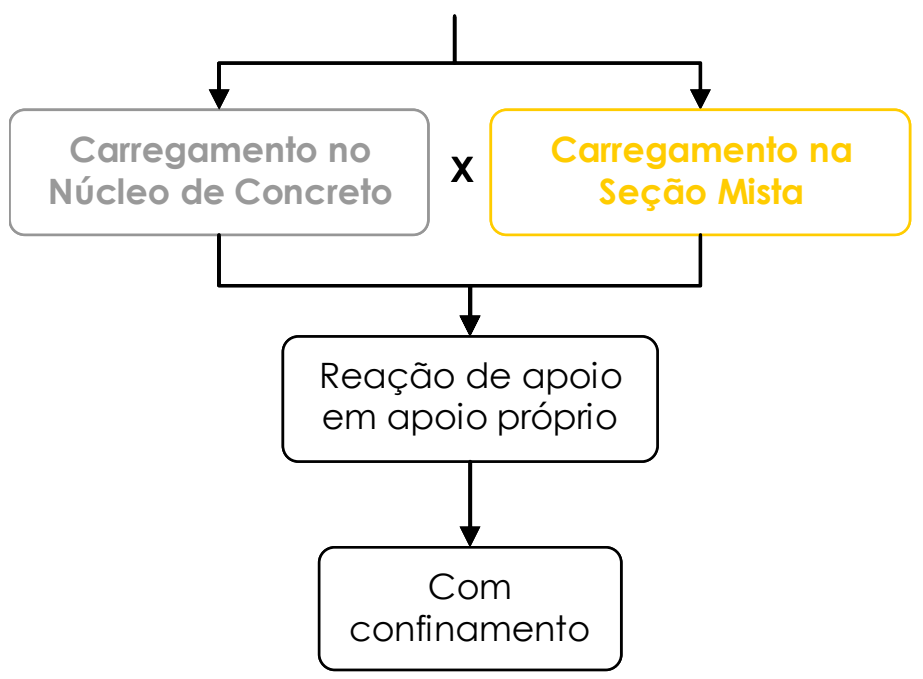

Figura 4.20. Fluxograma representativo da comparação 03. 


\subsubsection{Análise dos resultados da comparação 01: Teste a X Teste b}

Como representado na Figura 4.18, nos testes a e $\underline{b}$, o carregamento foi aplicado apenas no núcleo de concreto, a reação de apoio foi feita em um apoio próprio representado por um elemento de aço (um tarugo metálico), a diferença entre os dois testes esteve na consideração ou não do efeito de confinamento.

Observando o gráfico na figura 4.21, observa-se que as deformações com e sem o efeito de confinamento se sobrepõe no gráfico, apresentando uma diferença só nos últimos níveis de carregamento do ponto $\mathrm{Cl}$, que é o ponto mais próximo do carregamento.

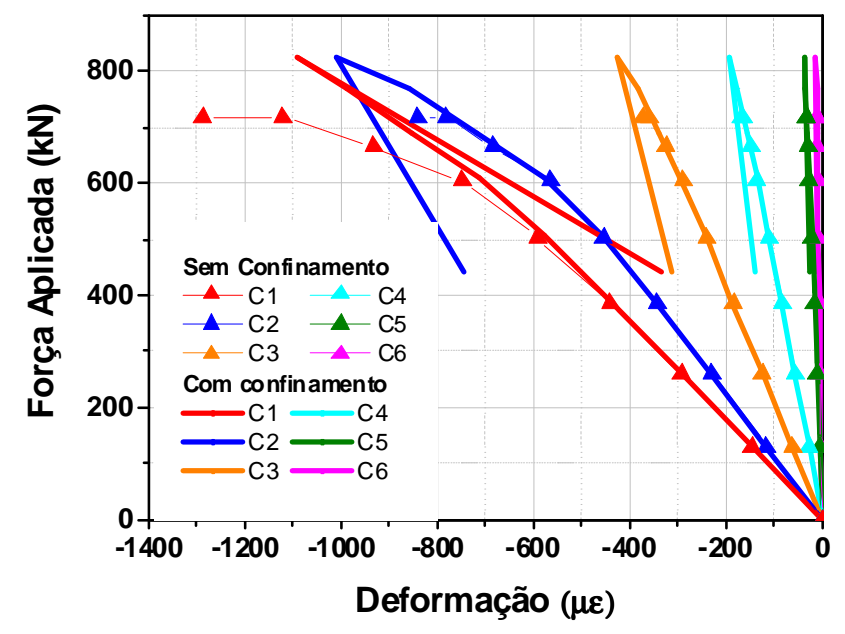

Figura 4.21. Comportamento Força aplicada versus Deformação no núcleo de concreto, com e sem consideração do efeito de confinamento.

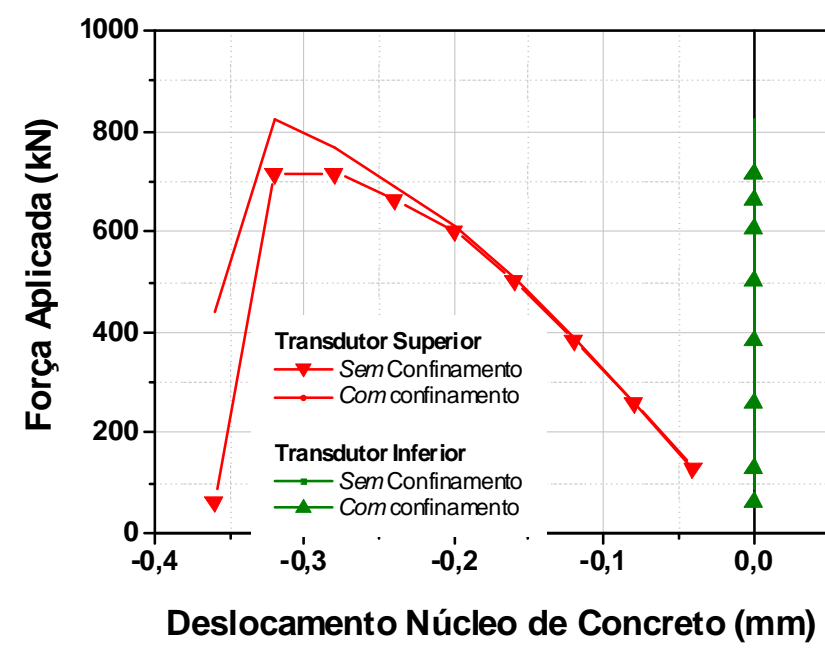

Figura 4.22 . Comportamento Força aplicada versus Deslocamento do núcleo de concreto, com e sem consideração do efeito de confinamento.

Quanto ao carregamento último, o valor encontrado para o teste com confinamento foi de $825,04 \mathrm{kN}$, enquanto que para o sem confinamento foi de $715,86 \mathrm{kN}$, uma diferença de aproximadamente $14 \%$.

Na Figura 4.22 pode-se observar a carga última no modelo com confinamento é maior do que a no modelo sem confinamento. Verifica-se também que para um valor de 
até $600 \mathrm{kN}$ na força aplicada, o deslocamento do transdutor superior para os dois testes foram praticamente idênticos, apresentando diferença para um valor de força aplicada acima de $600 \mathrm{kN}$.

Com relação ao deslocamento do transdutor inferior podem ser considerados iguais para os dois testes a e b.

\subsubsection{Análise dos resultados da comparação 02: Teste b X Teste d}

Nos testes b e $\underline{d}$, o carregamento foi aplicado no núcleo de concreto e considerouse o efeito de confinamento, entretanto a reação de apoio foi aplicada de forma diferente. No teste $b$ a reação é representada por um apoio próprio e no teste $d$ a reação de apoio foi considerada a próxima chapa de ligação restringindo o deslocamento na direção z da chapa.

Analisando o gráfico apresentado na Figura 4.22, observa-se que as deformações do concreto nos testes b e d não apresentam diferenças, as curvas dos dois teste são em sua totalidade sobrepostas.

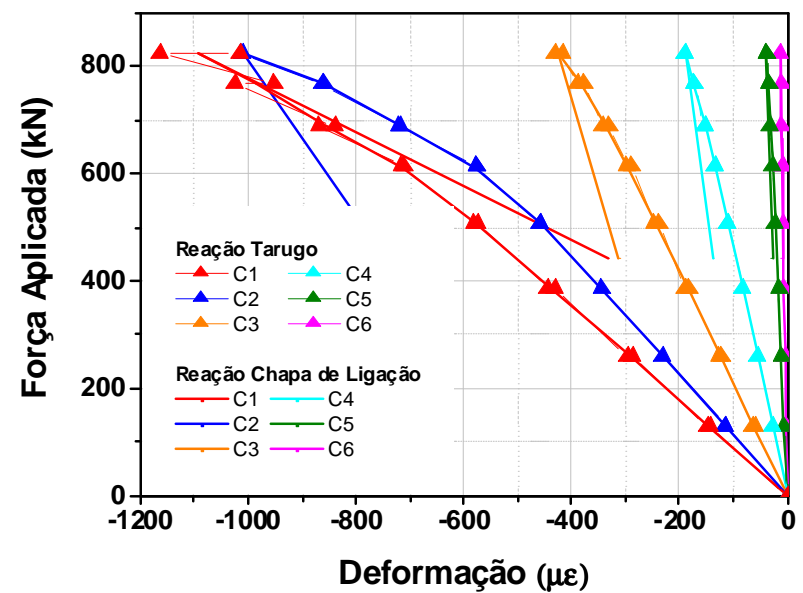

Figura 4.23. Comportamento Força aplicada versus Deformação no núcleo de concreto, de acordo com a forma de aplicação da reação de apoio.

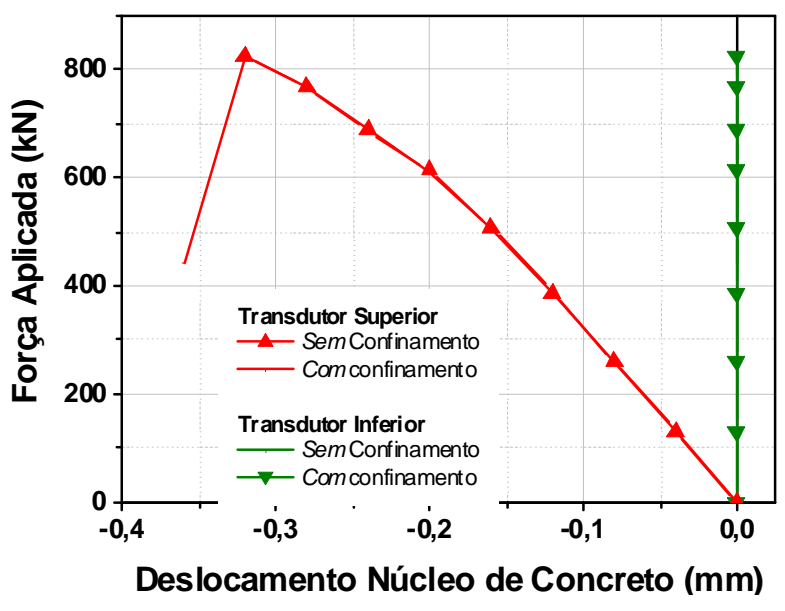

Figura 4.24. Comportamento Força aplicada versus Deslocamento do núcleo de concreto, de acordo com a forma de aplicação da reação de apoio. 


\subsubsection{Análise dos resultados da comparação 03: Teste a X Teste e}

Para os testes a e e a diferença encontra-se na forma de aplicação do carregamento: diretamente no núcleo de concreto (teste a) e na seção mista açoconcreto (teste e). Nos dois testes foram considerados o efeito de confinamento e a mesma forma de aplicação da reação de apoio, em um tarugo representando um apoio apropriado.

As Figuras 4.25 e 4.26 mostram os resultados comparativos relativos aos dois testes.

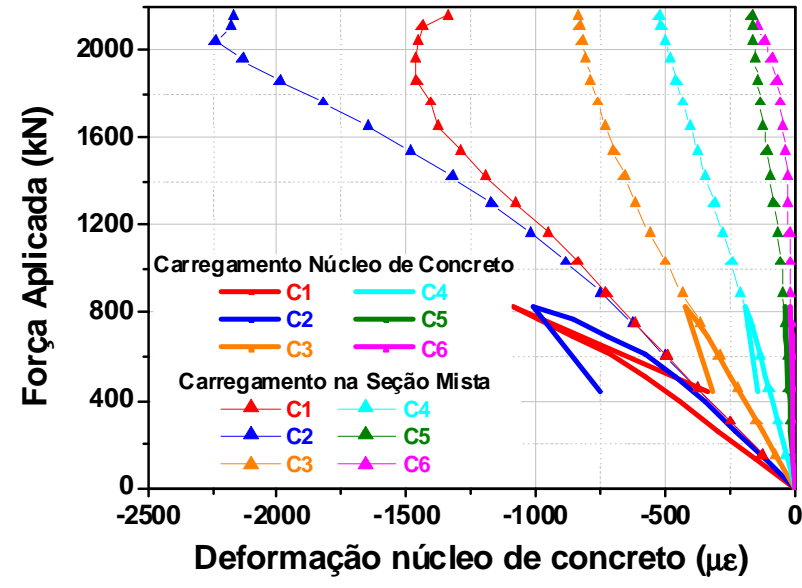

Figura 4.25. Comportamento Força aplicada versus Deformação no núcleo de concreto, de acordo com a forma de aplicação do carregamento.

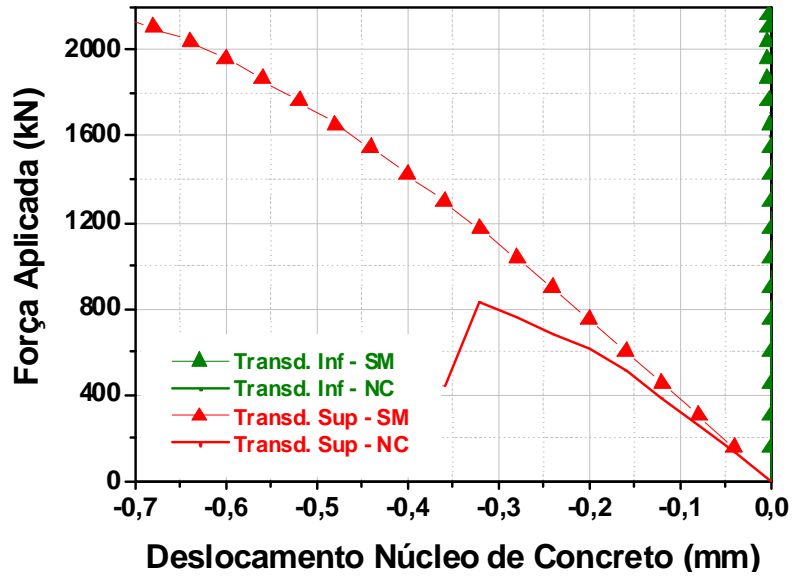

Figura 4.26. Comportamento Força aplicada versus Deslocamento do núcleo de concreto, de acordo com a forma de aplicação do carregamento.

Observa-se que o nível final de carregamento alcançado quando a carga é aplicada na seção mista chega a aproximadamente 2200 kN, enquanto no núcleo de concreto é de $825 \mathrm{kN}$.

Com relação às deformações, verifica-se que as curvas dos extensômetros C3, C4, C5 e C6 para os dois testes se sobrepõem. Para o extensômetro C2 as deformações até o nível de carregamento de $500 \mathrm{kN}$, as curvas dos dois testes se sobrepõem, entretanto para 
níveis de carregamento maior do que isso apresentam uma diferença um pouco significativa.

Para o extensômetro $\mathrm{Cl}$ as diferenças são observadas desde o início do carregamento entre os dois testes.

É importante observar que no teste em que se aplica o carregamento na seção mista as curvas C1 e C2 estão sobrepostas até $500 \mathrm{kN}$ e depois disso apresentam comportamentos diferentes entre si e diferente dos demais testes (curva $\mathrm{Cl}$ mostra deformações maiores do que as do extensômetro C2).

Em relação ao deslocamento do núcleo de concreto, verifica-se pela Figura 4.25 que o deslocamento superior, quando o carregamento é aplicado apenas no núcleo de concreto, é realmente maior do que quando o carregamento é aplicado na seção mista. Fato que já se esperava, uma vez que o núcleo de concreto desliza dentro do perfil de aço e sua aderência a ele é muito pequena para se evitar deslocamentos.

As deformadas do modelo para os dois testes são apresentadas nas Figuras 4.26 e 4.27.

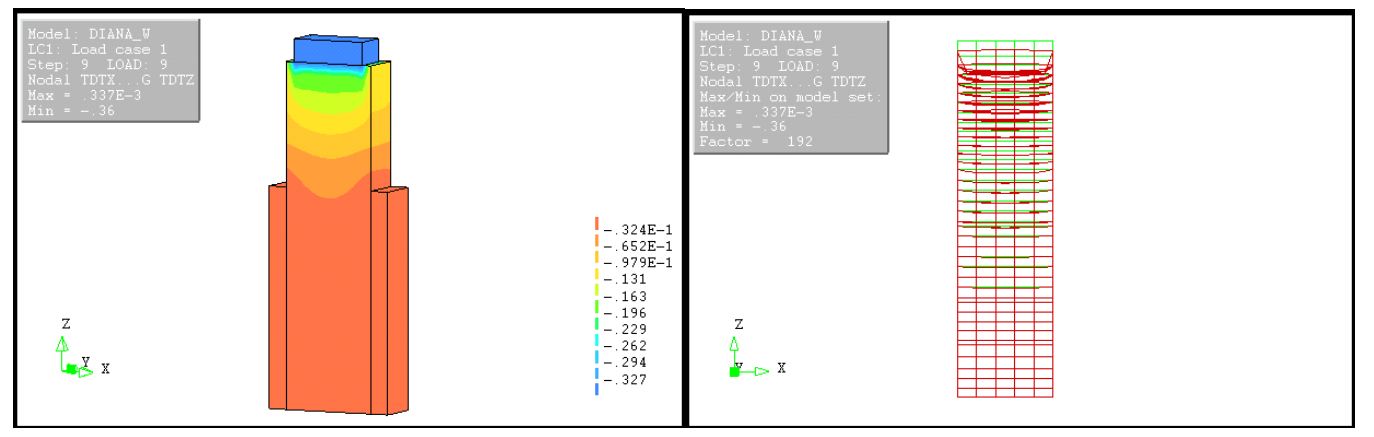

Figura 4.27. Deformada em z, do modelo para o carregamento apenas no núcleo de concreto. 


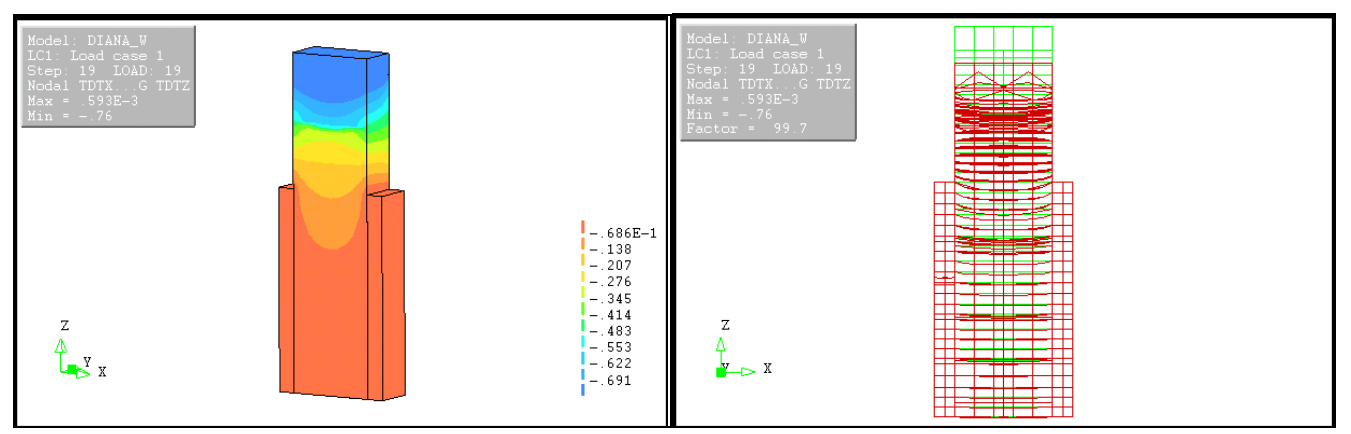

Figura 4.28. Deformada em z do modelo para carregamento na seção mista.

Verifica-se nitidamente que o modelo com carregamento na seção mista apresenta deformada nos nós acima da chapa de ligação bem diferente da deformada do modelo com carregamento no núcleo de concreto. Existe uma região em que ocorre uma concentração dos nós deformados.

O comportamento ao deslocamento do modelo com carregamento apenas no núcleo de concreto apresenta uma deformada mais uniforme.

Por conseqüência do deslocamento do núcleo de concreto ou da seção mista, as barras rosqueadas também sofreram deslocamentos, ocorrendo o chamado efeito de pino nelas.

As Figuras 4.29 e 4.30 ilustram a deformada das barras rosqueadas para os dois testes. Observa-se que a barra rosqueada do teste e apresenta deslocamentos maiores do que as barras do teste a. O efeito de pino é mais acentuado no teste e devido ao fato de que, quando é aplicado o carregamento, a seção mista possui rigidez muito maior (por causa do perfil de aço) do que a seção puramente de concreto. Desse modo a medida que vai sendo aplicado o carregamento no núcleo de concreto, esse vai se deformando (comprimindo). Se não houvesse a presença das barras rosqueadas, o núcleo de concreto sofreria pouca deformação comparada quando se tem as barras e o núcleo de concreto deslizaria assim que as aderências com o perfil de aço fossem quebradas. Mas quando se tem a presença das barras, essas impedem que o núcleo de concreto deslize inicialmente, 
desse modo o concreto vai sendo comprimido, até o momento em que não se consegue mais comprimi-lo e as barras rosqueadas começam a ser solicitadas ao cisalhamento, devido ao deslizamento do núcleo.
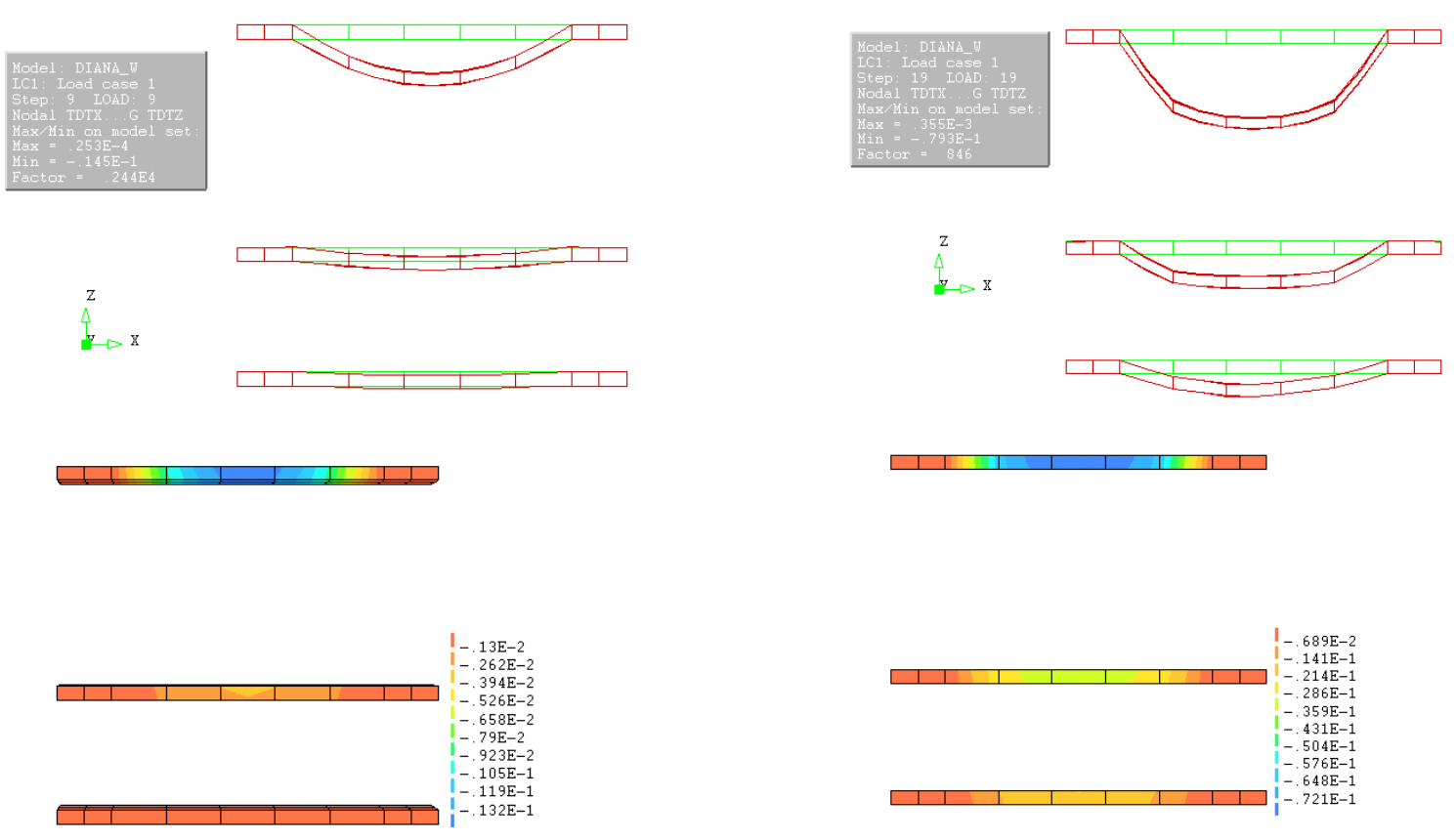

Figura 4.29. Deformada em z, da barra rosqueada

Figura 4.30. Deformada em z da barra rosqueada para o carregamento apenas no núcleo de concreto. para carregamento na seção mista.

Quando o carregamento é aplicado diretamente na seção mista, o escorregamento da seção é imediato após o acomodamento da estrutura. Dessa forma, as barras rosqueadas são mais solicitadas ao cisalhamento, sendo o efeito de pino mais expressivo nesse modelo. 


\subsection{Conclusão}

Analisando os três estudos comparativos realizados afirma-se que;

- A inclusão do efeito de confinamento aumenta, de forma não muito significativa, o valor da força última, da deformação do concreto e o valor do deslocamento do núcleo de concreto em um ensaio de cisalhamento.

- Não há diferença entre os valores de deformação e de deslocamento do concreto quando se aplica a reação de apoio em um tarugo (elemento apropriado) ou quando a própria chapa de ligação simula a reação de apoio através da restrição do seu movimento em z (vertical).

- A força última atingida em um modelo com carregamento na seção mista é aproximadamente o triplo da força para um modelo com carregamento aplicado no núcleo de concreto.

- As deformações do concreto entre os modelos com diferença de local para aplicação do carregamento são diferentes apenas para os extensômetros C1 e C2. Para os demais extensômetros, as curvas força aplicada versus deformação, se sobrepõem.

- As barras rosqueadas no modelo com carregamento na seção mista apresenta deslocamento em z maiores do que as do modelo com carregamento no núcleo de concreto.

\subsection{Comentários Finais}

A análise numérica correspondeu às expectativas. Apesar de seu desenvolvimento ter sido trabalhoso, foi de grande valia para o crescimento do conhecimento e da 
maturidade com relação a trabalhos envolvendo simulação numérica. Esperava-se apenas que os resultados com a presença do efeito de confinamento fossem mais representativos do que os resultados sem considerar o efeito de confinamento. Para as demais comparações relacionadas com a forma de aplicação da reação de apoio, esperava-se que realmente não houvessem diferenças significativas entre os resultados, que foi o que ocorreu.

Lamenta-se não ter sido possível inserir a questão do elemento de interface entre o perfil de aço e o núcleo de concreto, pois se acredita que os resultados de deformação do núcleo de concreto apresentariam diferenças significativas do que foi encontrado. Mas deixa-se aqui como sugestão para trabalhos futuros. 


\section{Comparação de Resultados}

No capítulo 02 foi apresentada a formulação que a ABNT NBR 8800:2008 traz a respeito do dimensionamento das ligações viga-pilar com barras rosqueadas. Neste capítulo será feito um estudo comparativo entre os resultados encontrados por meio da formulação proposta pela ABNT NBR 8800:2008, pela análise experimental e pela análise numérica e outros trabalhos na área. Deste modo será comparada a força de ruptura da ligação viga pilar determinada pelo ABNT NBR 8800:2008 com os resultados encontrados na análise experimental e numérica. As demais comparações, como: deslocamento e deformação do núcleo de concreto, deformação na barra rosqueada e deformação no pilar de aço, serão feitas entre os resultados experimentais e numéricos.

\subsection{Comparação entre os valores da Força de Ruptura ao Cisalhamento na Ligação Viga-Pilar - ABNT NBR 8800, Análise Experimental e Numérica}

De acordo com a ABNT NBR 8800:2008, a força de cisalhamento resistente nominal de uma barra rosqueada é expressa por plano de corte. Como o plano de corte na análise experimental passou pela rosca usou-se a equação 5.1, conforme especificado em norma. 


$$
F_{v, R d}=0,4 A_{b} f_{u b}
$$

(Equação 5.1)

Em que:

$A_{b}$ é a área bruta baseada no diâmetro do parafuso;

$f_{u b}$ é a resistência à ruptura do material do parafuso ou barra redonda rosqueada à tração;

De acordo com o ensaio de caracterização da barra rosqueada, o valor de resistência à ruptura determinada no ensaio de tração, $\mathrm{f}_{\mathrm{ub}}=785,43 \mathrm{kN}$.

O diâmetro da barra rosqueada utilizada foi de 5/8", que corresponde a 15,86 mm, $\log 0$ a $A_{b}=0,25 \pi d_{b}^{2}=197,56 \mathrm{~mm}^{2}$

Desse modo substituindo os valores de, $A_{b}, f_{u b}$ e $\gamma_{a 2}$, tem-se que:

$$
F_{v, R d}=0,4 A_{b} f_{u b}=(0,4)\left(197,55\left[\mathrm{~mm}^{2}\right]\right)\left(785,43\left[\frac{\mathrm{N}}{\mathrm{mm}^{2}}\right]\right)=61985,69 \mathrm{~N}=61,99 \mathrm{kN}
$$

O valor encontrado acima corresponde a resistência por plano de corte, de uma barra rosqueada ao cisalhamento. Como a resistência da ligação ao cisalhamento é dada pela resistência do conjunto de barras rosqueadas, e que uma barra utilizada no modelo estudado tem dois planos de corte, dessa forma, para conjunto de seis barras dos modelos tem-se um total de doze planos de corte, assim a equação 5.1 deve ser multiplicada por doze para se ter o valor da força resistente ao cisalhamento da ligação, que vale 743,88 kN.

Comparando o resultado acima com os resultados da análise numérica e a média dos resultados da análise experimental, observa-se que a NBR apresenta o valor mais conservador, seguido da análise numérica e por fim a análise experimental. A Tabela 5.1 apresenta os resultados da força de ruptura ao cisalhamento na ligação viga-pilar estudada para a ABNT NBR 8800:2008, para a análise experimental realizada e para a análise numérica. 
Tabela 5.1. Resultados de Força de Ruptura por Cisalhamento da Ligação

\begin{tabular}{c|c}
\hline Resultados & Força de Ruptura \\
ABNT NBR 8800:2008 & $743,21 \mathrm{kN}$ \\
Análise Experimental & $971,00 \mathrm{kN}$ \\
Análise Numérica & $825,04 \mathrm{kN}$ \\
\hline
\end{tabular}

\subsection{Comparação Análise experimental versus Análise numérica}

Neste subitem serão comparados os resultados experimentais que dizem respeito ao modelo sem conector de cisalhamento, com os resultados encontrados na análise numérica. Serão utilizados como resultado da análise numérica para fazer o comparativo com os resultados experimentais, os do teste $b$ em que se considera o efeito de confinamento, a aplicação do carregamento apenas na seção de concreto e reação de apoio feita em um apoio apropriado.

Desse modo será apresentado o estudo comparativo por meio de representações gráficas, da seguinte forma:

- Força aplicada versus deslocamento do núcleo de concreto;

- Força aplicada versus deformação do núcleo de concreto;

As Figuras 6.1 e 6.2 apresentam respectivamente as representações gráficas que serão usadas para comparar o teste experimental e numérico. 


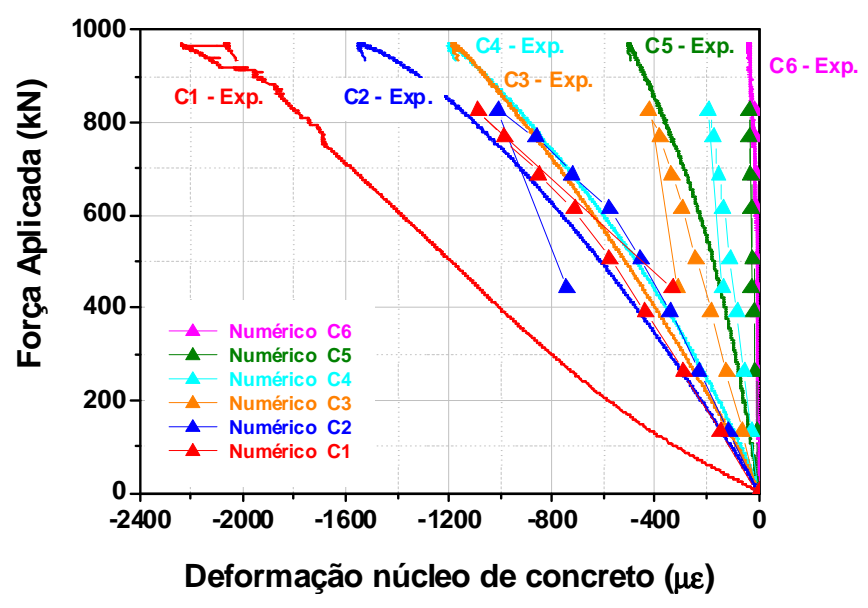

Figura 5.1. Comportamento Força aplicada versus Deformação no núcleo de concreto.

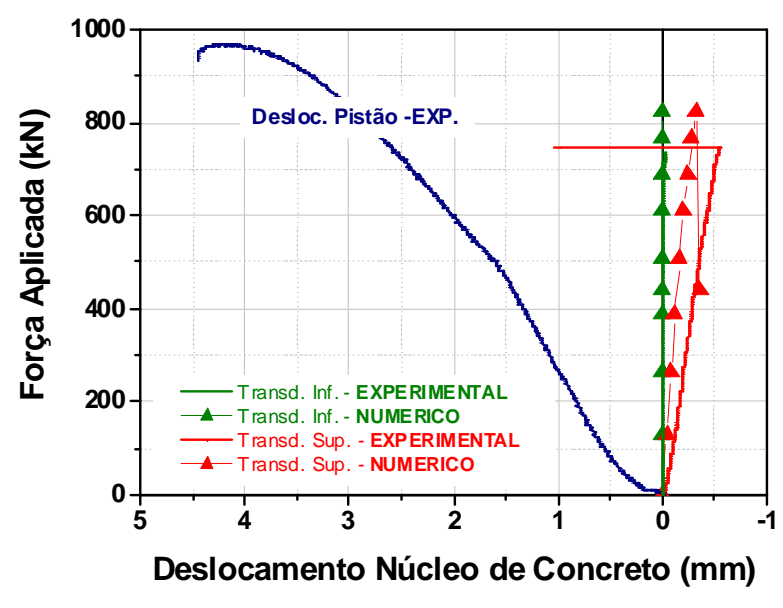

Figura 5.2. Comportamento Força aplicada versus Deslocamento do núcleo de concreto.

Como se esperava, o teste numérico é mais conservador do que o experimental. Os valores das deformações para um nível de carregamento é inferior no teste numérico. Entretanto observa-se que o lógica seqüencial de curvas é a mesma nos dois testes. A curva C1 apresenta deformações maiores, seguida da curva C2, assim por diante até a curva C6.

Quanto ao deslocamento do núcleo de concreto, o teste numérico também é mais conservador. O transdutor superior registrou deslocamentos para o núcleo de concreto, maiores do que no modelo experimental para o modelo numérico.

\subsection{Comparação com o trabalho de Silva (2006)}

Em função dos valores de deslocamento encontrados na análise experimental podese afirmar que barras rosqueadas funcionam como obstáculos ao deslizamento do núcleo de concreto, reduzindo significativamente esse deslizamento. Isso pode ser confirmado pelo comportamento mostrado na Figura 6.3, em que são comparados os deslizamentos obtidos por Silva (2006) com aqueles obtidos neste estudo. 
No caso do modelo físico ensaiado por Silva (2006), não haviam barras rosqueadas, apenas o pilar misto preenchido de mesma geometria. A força última registrada no modelo ensaiado por Silva foi de 209 kN. Dessa forma, o aumento de resistência chega a ser de aproximadamente $460 \%$, quando as barras rosqueadas são consideradas.

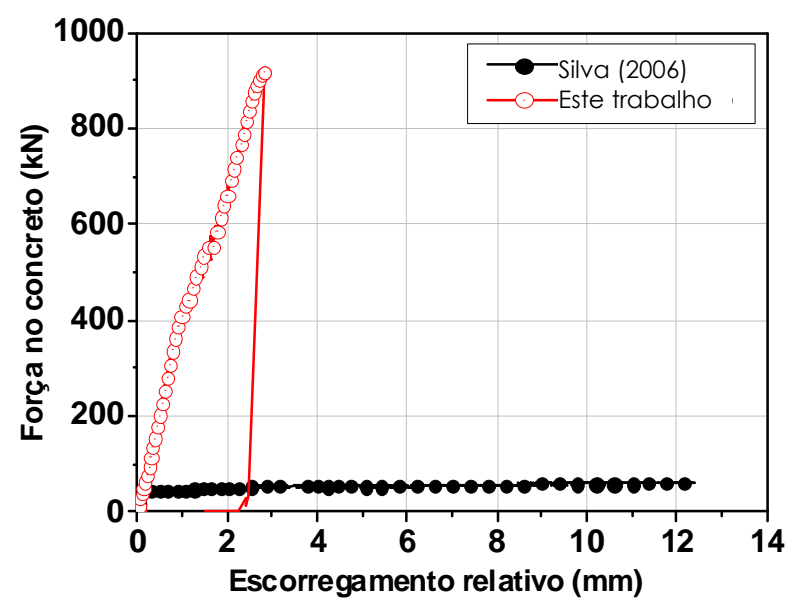

Figura 5.3. Comparação do deslizamento relativo aço-concreto

\subsection{Comparação com o trabalho de Prion (1994)}

Associando os modos de falha identificados por Prion (1994) às deformações axiais registradas nas barras rosqueadas, o modo de falha das barras é fruto da associação entre cisalhamento e flexão, predominando o cisalhamento (modo de ruptura da barra - Figura 2.20a).

Assim como Príon verificou durante a transferência de esforços de cisalhamento o "efeito de pino", também se observou esse comportamento em nosso estudo. A análise numérica mostra perfeitamente esse comportamento. 


\subsection{Considerações finais}

Comparando os resultados experimentais aos resultados numéricos, conclui-se que os resultados numéricos são mais conservadores do que os resultados experimentais.

O comportamento verificado na análise numérica corresponde às conclusões feitas na análise experimental no que diz respeito às barras rosqueadas e deformação no núcleo de concreto.

Os resultados obtidos nesse trabalho são condizentes com as conclusões obtidas por Prion (1994) e complementam o trabalho de Silva (2006), que também faz parte da mesma linha de pesquisa. 


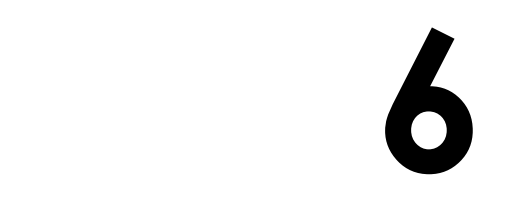

\section{Conclusão}

Neste capítulo são sintetizadas as principais conclusões geradas a partir do estudo experimental e numérico a respeito do comportamento da transferência de forças de cisalhamento na ligação viga-pilar com barras rosqueadas e na interface perfil de aço e núcleo de concreto. Ao final do capítulo apresenta-se algumas sugestões para a continuidade deste trabalho, visando nortear estudos que complementem e esclareçam fenômenos aqui identificados.

Na análise experimental observou-se que a aplicação do carregamento no núcleo de concreto (NC) provoca deslizamento do mesmo e por conseqüência ruptura da ligação por cisalhamento das barras rosqueadas. As barras rosqueadas rompem por cisalhamento, de forma não simétrica, ou seja, apenas um dos lados da ligação que rompe, podendo ocorrer também ruptura do tipo simétrica.

A presença de dispositivos de transferências de esforços, como as cantoneiras e os conectores tipo pino com cabeça, contribuem de forma muito significativa para a transferência de esforços do núcleo de concreto para o perfil de aço, entretanto não aumentam a capacidade resistente à ruptura.

Dentre os conectores de cisalhamento estudados, as cantoneiras apresentam maior eficiência que os conectores tipo pino com cabeça (stud-bolts), não apenas na função de transferir os esforços de cisalhamento ao perfil de aço, mas também na restrição ao escorregamento do núcleo de concreto, sendo que a associação cantoneiras-barras rosqueadas mostrou-se muito positiva. 
As barras rosqueadas ajudam no impedimento ao deslizamento do núcleo de concreto e quando há associação com conectores de cisalhamento, essa restrição se torna mais significativa.

Grande parte da força aplicada no ensaio é absorvida pelo núcleo de concreto. Porém ocorre diminuição da deformação ao longo do núcleo de concreto, pois os esforços absorvidos pelo NC passam a ser transferidos para o perfil de aço, quando há conectores de cisalhamento.

Os resultados experimentais e numéricos apresentaram o mesmo comportamento para as barras rosqueadas. No estudo numérico, os resultados alcançados são um pouco mais conservativos do que os experimentais. É possível observar de forma clara na análise numérica o efeito de pino sofrido pelas barras redondas rosqueadas, como Príon (1994) deduziu.

O estudo comparativo entre os testes realizados na análise numérica sanou algumas dúvidas em relação à interferência do efeito de confinamento nos pilares mistos preenchidos e em relação ao comportamento do modelo quando o carregamento é aplicado apenas no núcleo de concreto e na seção mista.

No desenvolvimento do trabalho observou-se que algumas decisões poderiam ter sido diferentes gerando resultados melhores. A primeira sugestão é com relação à inclusão do elemento de interface entre o perfil de aço e o núcleo de concreto, pois observou-se que a aderência aço-concreto é um fator que provavelmente apresentaria resultados um pouco melhores se tivesse sido considerado na análise numérica.

Uma segunda sugestão é procurar variar o diâmetro das barras, de forma a provocar um esmagamento do concreto, em vez do cisalhamento das mesmas, que seria uma outra forma de ruptura dos pilares mistos preenchidos, como colocado por Príon (1994). 
Por fim ainda como sugestão, a análise das deformações no perfil de aço obtidas na análise numérica e sua comparação com os resultados experimentais, quando há conectores de cisalhamento no perfil de aço e quando não há. 



\section{Referências Bibliográficas}

ASSOCIAÇÃO BRASILEIRA DE NORMAS TÉCNICAS. (1986). Projeto e execução de estruturas de aço de edifícios. Procedimento NBR 8800. Rio de Janeiro.

ASSOCIAÇÃO BRASILEIRA DE NORMAS TÉCNICAS. (2008). Projeto de estruturas de aço e de estruturas mistas de aço e concreto de edifí́cios. Procedimento NBR 8800. Rio de Janeiro.

BARROS, R. (2009). Análise de blocos de concreto armado sobre duas estacas com cálice totalmente embutido mediante presença de viga de travamento. Dissertação (Mestrado), Escola de Engenharia de São Carlos, Universidade de São Paulo, São Carlos, São Paulo.

BIANCHI, F. R. (2002) Análise do comportamento dos pilares mistos considerando a utilização de conectores de cisalhamento. Dissertação, Vitória, Espírito Santo.

CEDERWALL, K.; ENGSTROM, B.; GRAUERS, M. (1990). High-strength concrete used in composite columns. In: HESTER, W. T., (Ed.) High-strength concrete: second international symposium. Detroit, ACl. p.195-214. (ACI SP-121).

DE NARDIN, S. (2003). Pilares mistos preenchidos: estudo da flexo-compressão e de ligações viga-pilar. São Carlos. 323p. Tese (Doutorado) - Escola de Engenharia de São Carlos, Universidade de São Paulo. 
DE NARDIN, S.; SOUZA, A.S.C, EL DEBS, A. L. H. C. (2007). Detalhes entre pilares mistos preenchidos e vigas de aço. Artigo técnico, Revista Construção Metálica. Pg. 23 - 26.

DIANA (2005a). DIANA Finite Element Analysis. User's manual release 9. Element Library. TNO DIANA, Delft, Netherland.

DIANA (2005b). DIANA Finite Element Analysis. User's manual release 9. Material Library. TNO DIANA, Delft, Netherland.

FARIAS, R. S. (2008). Estudo teórico-experimental do efeito da laje na transferência de forças em ligações viga-pilar misto preenchido. Dissertação (Mestrado) - Escola de Engenharia de São Carlos, Universidade de São Paulo, São Carlos.

FEENSTRA, P. H.; BORST, R. (1993). Aspects of robust computational modeling for plain and reinforced concrete. Heron, v.38, n.04, Delft, Netherlands.

FUJIMOTO, T.; MUKAI, K.; NISHIYAMA, I.; SAKINO, K. (2004). Behavior of Eccentrically Loaded Concrete-Filled Steel Tubular Columns. Journal of Structural Engineering. ASCE / FEBRUARY 2004. p. 203-212.

GARDNER, A. P.; GOLDSWORTHY, H. M. (2005). "Experimental investigation of the stiffness of critical components in a moment-resisting composite connection", Journal of Constructional Steel Research, v. 61, n.5, p.709-726.

HUANG, C.S.; YEH, Y.-K.; LIU, G.-Y.; HU, H.-T.; TSAI, K.C.; WENG, Y.T.; WANG, S.H.; WU, M.-H. (2002). Axial load behavior of stiffened concrete-filled steel columns. Journal of Structural Engineering, ASCE, v.128, n.9, p.1222-1230, Sep.

JOHANSSON, M. (2003). Composite action in connection regions of concrete-filled steel tube columns. Steel and Composite Structures, v.3, n.1. Feb. 
LIU, D.; GHO, W.-M.; YUAN, J. (2003). Ultimate capacity of high-strength rectangular concretefilled steel hollow section stub columns. Journal of Constructional Steel Research. v.59, n.12, p.1499-1515. Dec.

MCMACKIN, P. J.; SLUTTER R. G.; FISHER W. J. (1973). Headed Steel Anchor under Combined Loading.

OLIVEIRA, Walter Luiz Andrade de (2008). Análise teórico-experimental de pilares mistos preenchidos de seção circular. Tese, São Carlos, São Paulo, Brasil.

PRION, H. G. L.; MCLELLAN A. B. Through-bolt connections for concrete-filled hollow structural steel sections. British Library.

QUEIROZ, G.; PIMENTA, R. J.; MATA, L. A. C. (2001). Elementos das estruturas mistas açoconcreto. Ed. O Lutador.

RICLES, J. M.; PENG, S. W.; LU, L. W. (2004). "Seismic behavior of composite concrete filled steel tube column-wide flange beam moment connections", Journal of Structural Engineering, v.130, n.2, p.223-232.

ROEDER, C.W.; CAMERON, B.; BROWN, C.B. (1999). Composite action in concrete filled tubes. Journal of Structural Engineering, ASCE, v.125, n.5, p.477- 484. May.

SAKINO, K.; NAKAHARA, H.; MORINO, S.; NISHIYAMA, A. (2004). Behavior of centrally loaded concrete-filled steel-tube short columns. Journal of Structural Engineering, ASCE. v.130, n.2, p.180-188. Feb.

SHAMS, M.; SAADEGHVAZIRI, M.A. (1997). State of the art of concrete-filled steel tubular columns. ACI Structural Journal, ACl, v.94, n.5, p.558-571. Sep-Oct. 
SILVA, R.D. (2006). Estudo da aderência aço-concreto em pilares mistos preenchidos. Dissertação (Mestrado) - Escola de Engenharia de São Carlos, Universidade de São Paulo, São Carlos.

VIEST, I. M., COLACO, J. P., FURLONG, R. W., GRIFFIS, L. G., LEON, R. T., WYLLIE JR., L.A. (1997); Composite construction design for buildings; Ed. McGraw-Hill.

VIRDI, K. S.; DOWLING, P. J. (1980). Bond strength in concrete filled steel tubes.IABSEInternational Association for Bridge and Structural Engineering, n.03, p.125- 137, August.

UY, B. (1998). Local and post-local buckling of concrete filled steel welded box columns. Journal of Constructional Steel Research. v.47, p.47-72. 


\section{APÊNDICE A}

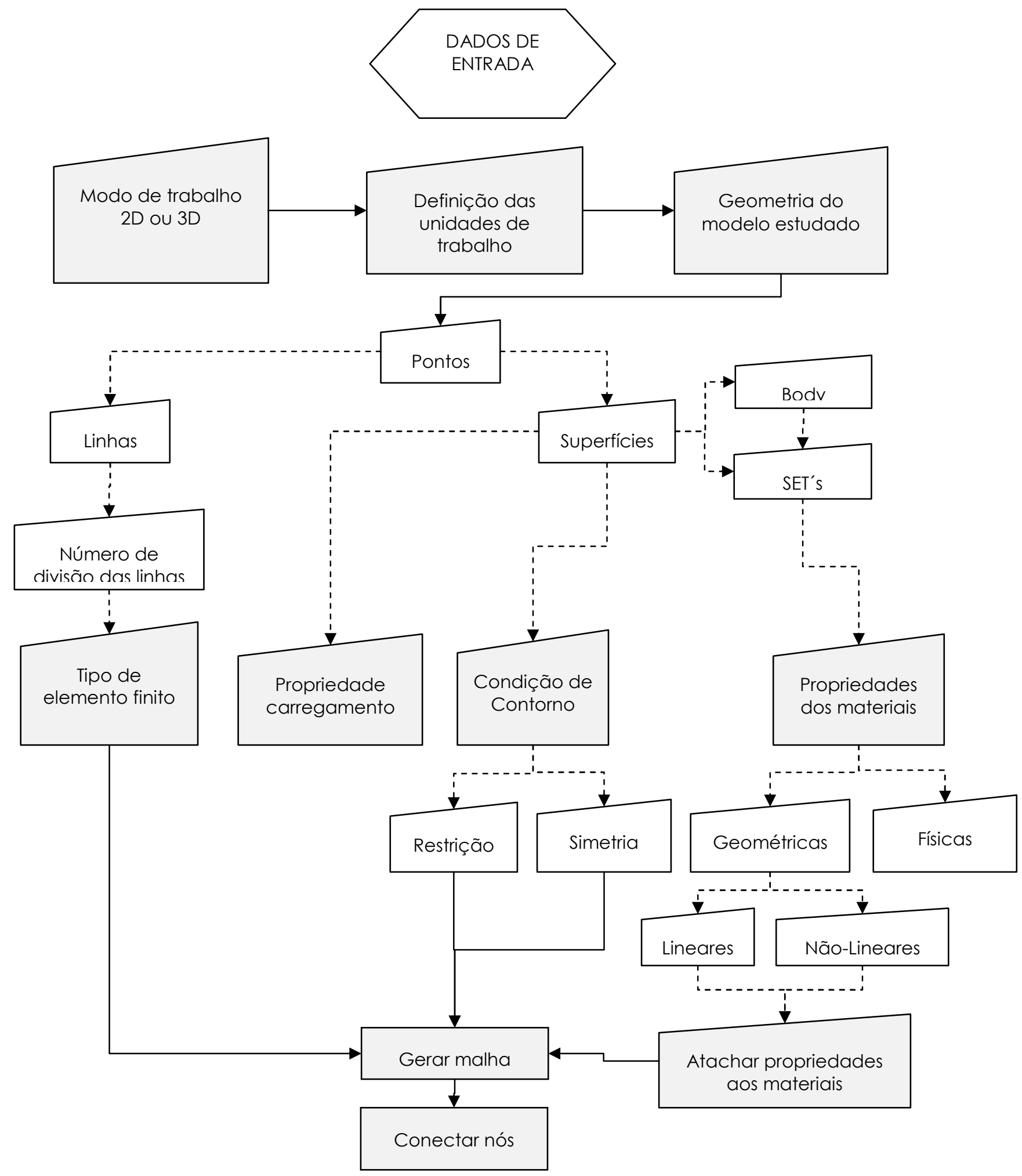




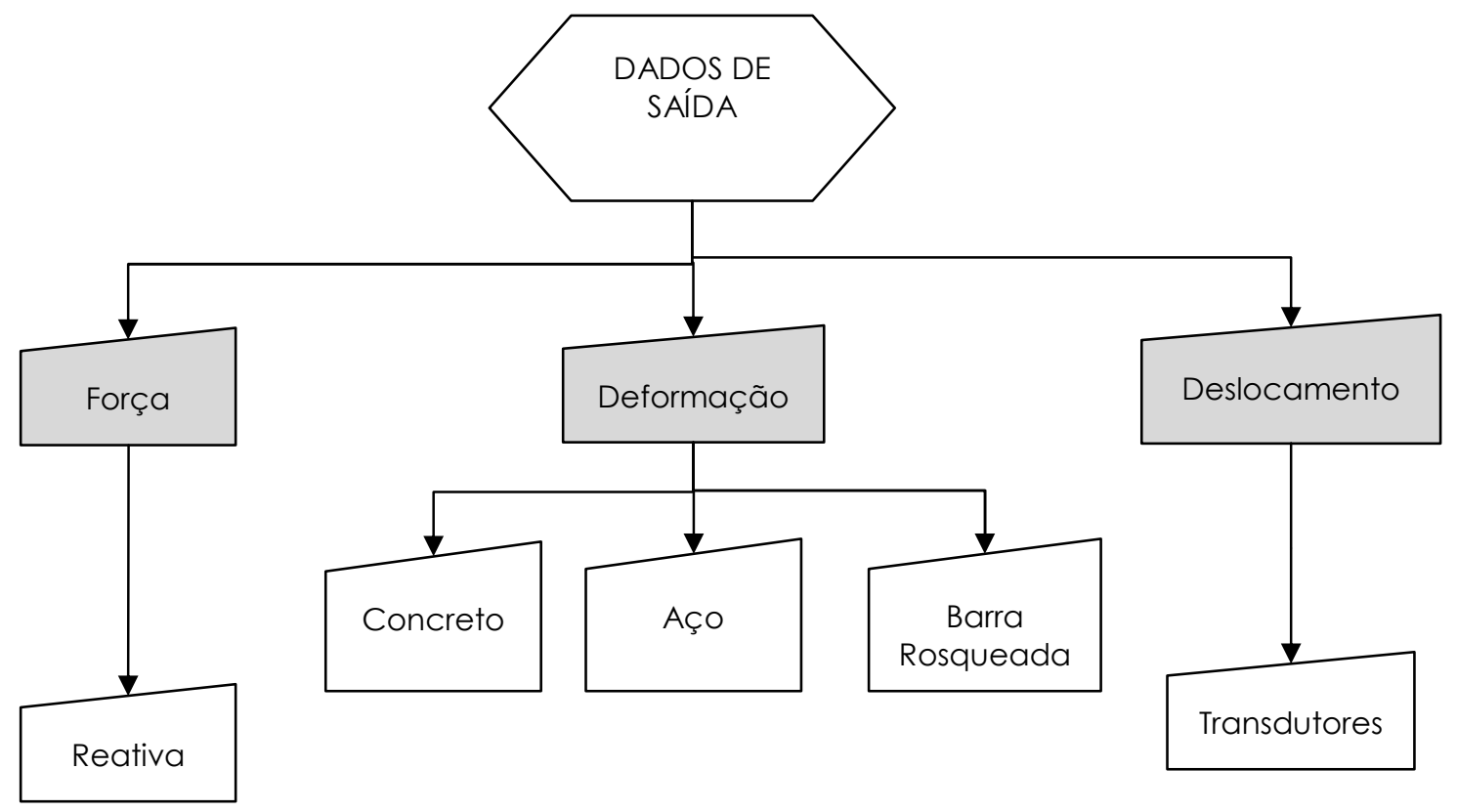

